\title{
Five new (extinct?) species of Atelopus (Anura: Bufonidae) from Andean Colom- bia, Ecuador, and Peru
}

\author{
LUIS A. COLOMA ${ }^{1}$, WILLIAM E. DUELLMAN ${ }^{2}$, ANA ALMENDÁRIZ C. ${ }^{3}$, SANTIAGO R. RON ${ }^{1}$, \\ ANDREA TERÁN-VALDEZ ${ }^{1} \&$ JUAN M. GUAYASAMIN ${ }^{1}$ \\ ${ }^{1}$ Museo de Zoología, Escuela de Biología, Pontificia Universidad Católica del Ecuador, Av. 12 de Octubre 1076 y Roca, Aptdo. 17-01- \\ 2184,Quito,Ecuador.lcoloma@puce.edu.ec,srron@puce.edu.ec,jmguayasamin@gmail.com \\ ${ }^{2}$ Biodiversity Institute, The University of Kansas, Lawrence, Kansas 66045-7561, USA. duellman@ku.edu \\ ${ }^{3}$ Museo de Historia Natural Gustavo Orcés V., Escuela Politécnica Nacional, Aptdo. 2759, Quito, Ecuador. \\ ana.almendariz@epn.edu.ec
}

\begin{abstract}
We studied populations of frogs of the genus Atelopus from the Pasto Massif of the Andes in southern Colombia and northern Ecuador, and from the Huancabamba depression in southern Ecuador and northern Perú and conclude that they belong to six species, five of which are described as new to science. Atelopus angelito is recorded for the first time from Ecuador and its range is extended $183 \mathrm{~km}$ (airline) southwest of its type locality in Departamento del Cauca, Colombia. We distinguish the five new species from similar ones using features of coloration, skin texture, and morphometrics. We also include osteological data for four of the new species. A putative hybrid zone at Provincia Imbabura, Ecuador, is proposed to exist between the non-sister taxa A. ignescens and one of the new species. Because recent records of four of the new species and A. angelito are lacking despite search efforts, we hypothesize that they are possibly extinct, as are many other Andean Atelopus. Thus, we categorize these species, applying IUCN Red List criteria, as Critically Endangered (Possibly Extinct). No search efforts have been carried out for one new species (from La Victoria, Colombia); thus, it is included under the Data Deficient category. The conservation of Atelopus is briefly discussed.
\end{abstract}

Key words: Anura; Bufonidae; Atelopus angelito; Atelopus ardila sp. nov.; Atelopus gigas sp. nov.; Atelopus orcesi sp. nov.; Atelopus pastuso sp. nov.; Atelopus podocarpus sp. nov.; Colombia; Conservation; Ecuador; Extinction; Morphology; New species; Osteology; Perú, Systematics

\section{Resumen}

Estudiamos poblaciones de ranas del género Atelopus del Nudo de Pasto en los Andes del sur de Colombia y norte de Ecuador, y de la Depresión de Huancabamba en el sur de Ecuador y norte de Perú y concluimos que pertenecen a seis especies, cinco de las cuales son descritas como nuevas para la ciencia. Reportamos por primera vez la presencia de Atelopus angelito en Ecuador, lo cual extiende su rango de distribución 183 km en línea recta hacia el suroeste de su localidad tipo en el Departamento del Cauca, Colombia. Distinguimos a las cinco especies nuevas de otras similares sobre la base de caracteres de coloración, textura de la piel y morfometría. Además, incluimos datos osteológicos de cuatro de las especies nuevas. Se propone la existencia de una zona de híbridos en la provincia de Imbabura, Ecuador, entre Atelopus ignescens y una de las especies nuevas, las cuales no son especies hermanas. Debido a la ausencia de registros de cuatro de las especies nuevas y de A. angelito, a pesar de esfuerzos de búsqueda, asumimos que estas especies están posiblemente extintas, al igual que muchas otras especies de Atelopus Andinos. Por tanto, categorizamos a estas especies, aplicando los criterios de la Lista Roja de la UICN, como Críticamente Amenazadas (Posiblemente Extintas). No existen intentos de búsqueda de una especie nueva (proveniente de La Victoria, Colombia); por lo cual la incluimos en la categoría de Datos Deficientes. Se discute brevemente sobre la conservación de especies de Atelopus.

Palabras claves: Anura; Bufonidae; Atelopus angelito; Atelopus ardila sp. nov.; Atelopus gigas sp. nov.; Atelopus orcesi sp. nov.; Atelopus pastuso sp. nov.; Atelopus podocarpus sp. nov.; Colombia; Conservación; Ecuador; Especies nuevas, Extinción; Morfología; Osteología; Perú, Sistemática 


\section{Introduction}

The taxonomy of the neotropical anuran genus Atelopus is still far from being completed (La Marca et al. 2005; Rueda-Almonacid et al. 2005). Currently, there are 92 species formally recognized (updated from AmphibiaWeb 2009; including new species described herein). Coloma et al. (2007) estimated that no less than 60-70 species were yet to be described, among which about half of them were deposited in scientific collections awaiting formal specific status recognition. Although knowledge of Atelopus diversity and biology may never be completed, given the extinctions they have suffered (La Marca et al. 2005; Pounds et al. 2006), the clarification of its taxonomy and systematics has become a high priority in order to confront its crisis (Lötters 2007).

Among specimens deposited at museums, there are several high Andean populations of Atelopus from Nudo de Pasto in the Andes in southern Colombia and northern Ecuador and from the Huancabamba depression in the Andes of southern Ecuador and northern Peru that belong to six species, five of which are undescribed. Gray (1983) and Coloma et al. (2000) suggested that populations from Guachucal (Departamento Nariño), El Ángel (Provincia Carchi), and Laguna La Cocha, (Departamento Nariño) were not conspecific with A. ignescens Cornalia; these were cited either as Atelopus "ignescens" by Ardila-Robayo and Maldonado-Silva (2004) and Cepeda Quilindo and Rueda Almonacid (2005), or Atelopus sp. 17 by Almendáriz and Cisneros (2005). Herein, we provide support of their distinctiveness and, in addition, recognize two new species within these populations. Additionally, while examining specimens from Nudo de Pasto, we found two new undescribed taxa. Thus, we describe and report them herein. Yánez-Muñoz and Altamirano B. (2005) recorded a hypothetical new species (under the name Atelopus sp. 14) from Río La Plata, Comunidad de Morán, Provincia Carchi, Ecuador. We identified it, and this represent A. angelito Ardila-Robayo and RuizCarranza, which was previously only known from Departamento del Cauca, Colombia. Also, Almendáriz (2005) reported a putative new species from the Provincia Loja in the Andes of southern Ecuador. This species was included in a phylogenetic analysis, using molecular data, of populations throughout the high Andes of Ecuador (Guayasamin et al. 2010) and it was confirmed that it belongs to a new species that we describe herein.

\section{Materials and methods}

All localities were georeferenced from verbal locality data using digital maps in ArcMap (ESRI 2008). Thus, coordinates and in some cases elevations are only approximations. Mean annual precipitation and mean annual temperature for the type localities were extracted from the WORLDCLIM dataset (http://www.worldclim.org; Hijmans et al. 2005). Institutional abbreviations follow Frost (2009).

Sex of adults was determined by external features, defined by Coloma et al. (2000), or through dissection. We use the term spiculae to refer to pustular warts, and the term coni to refer to spiculae with pointed projections. Measurements are in millimeters $(\mathrm{mm})$; they were taken from preserved adults with digital calipers to the nearest 0.1. Abbreviations and definitions of measurements follows Coloma et al. (2000); they are SVL (snout-vent length), TIBL (tibia length), FOOT (foot length), HLSQ (head length from the squamosal to snout), IOD (interorbital distance), HDWD (head width), EYDM (eye diameter), EYNO (eye to nostril distance), ITNA (internarial distance), RDUL (length of flexed forearm), HAND (hand length), THBL (thumb length), and SW (sacrum width). We indicate webbing formulae in the manner described by Savage and Heyer (1997). Finger nomenclature follows Fabrezi and Alberch (1996), Guayasamin and Trueb (2007), Coloma et al. 2007. Fabrezi and Alberch showed that Digit I was lost. Thus, fingers are numbered preaxially to postaxially from II-V. To facilitate comparisons, abbreviations and definitions of measurements, diagnosis, and osteological nomenclature mostly follow Coloma (2002) and references therein. We added a character in the diagnosis, which is minute gray stippling present or absent on dorsum of body. When viewed with magnification under a dissecting microscope the stippling is regularly distributed (Coloma et al. 2007: Fig. 7A). 
General features are illustrated, whereas features that show variation considered systematically useful are also described. Data on skeletons were taken from cleared and either alizarin-red or alizarin-red-alcian-blue stained specimens; they were prepared following a modified version of the technique of Dingerkus and Uhler (1977). Osteological data for A. orcesi sp. nov. were taken from X-ray images acquired with a Thermo Kevex x-ray machine, Model PXS5-925EA-LV with the following settings: max volt: $80 \mathrm{Kv}$, max power: 8 Watts, and max current: $0,18 \mathrm{~mA}$. Color slides, digital images cited in the text, and holotype virtual animations (provided as hyperlinks) of four species are deposited at QCAZ and displayed on AmphibiaWebEcuador (http://zoologia.puce.edu.ec/Anfibios.aspx).

Multivariate analysis was used to assess the degree of morphometric differentiation between a population of Atelopus ignescens and one of the new species. We compared SVL and eight size-corrected morphological variables of $A$. ardila sp. nov. (KU 154583, 169262-64, 169268-71, 169273-76, 169278-83, 169285-91, 169293-304, 1692306-16, 169318-35, 200207-12, 200214-15, 200218-39, QCAZ 24467-71, 63 males and 38 females of $A$. ardila sp. nov. from road from Pasto to La Cocha, Departamento Nariño, Colombia) vs populations of A. ignescens (MNHG 2273.48, 2273.61, 2273.81-82, 2273.84-93, 2273.95, 2273.97, 2409.95, 2409.98-99, 2410.1-6, 14 males and 11 females of A. ignescens from Páramo La Virgen, Provincia Napo, Ecuador; QCAZ 704, 707, 709-16, 1857, two males and nine females from approximately $20 \mathrm{~km}$ (airline) south east of Latacunga, on road from San Miguel de Salcedo to Lagunas de Anteojos and towards the east, Provincia Cotopaxi; QCAZ 254, 385-86, 8797, 3 males and 1 female from Laguna de Limpiopungo, Provincia Cotopaxi). JMP 8.0.1, Statistical discovery (SAS Institute Inc., 2009), was used to perform statistical analyses. To remove the effect of covariation with SVL, Principal Components Analysis (PCA) was applied to the residuals of the linear regressions between SVL and eight morphometric variables (all values log transformed). Three PCA components with eigenvalues $>1$ were retained. To determine whether separation in morphometric space was statistically significant, we did a multivariate analysis of variance (MANOVA), in which the fixed factor was the species and dependent variables were PCA axis scores. We present an overall statistic as well as tests of between-subject effects to determine which PCA axis accounts for significance in the overall test.

We categorized the conservation status of five species treated herein by applying IUCN categories, criteria and guidelines (IUCN 2001; IUCN Standards and Petitions Working Group 2008). We measured the area of extent of occurrence for the species as the area contained by a minimum convex polygon, defined by all its localities with ArcMap 9.3 (ESRI 2008).

\section{Results}

\section{Atelopus ardila sp. nov.}

Holotype. KU 200214, adult gravid female, from $7.5 \mathrm{~km}$ E of Pasto, on road to Laguna La Cocha (= Lago Guamuez) (ca. $1^{\circ} 12^{\prime} \mathrm{N}, 77^{\circ} 13^{\prime} \mathrm{W} ; 2800 \mathrm{~m}$ ), Vereda San Fernando, Departamento Nariño, Colombia, obtained on 25 February 1984 by Patricia A. Burrowes and Benjamín del Castillo.

Paratypes. All (except ICN 3406 and specimens from Hacienda San Gerardo at Volcán Galeras) are from the road from Pasto to Laguna de la Cocha, Vereda San Fernando, Departamento Nariño, Colombia; KU 200207-12, 200215-18 (3 females, 7 males), with same data as holotype; KU 200213, male, from $7.5 \mathrm{~km}$ E of Pasto $(2800 \mathrm{~m})$ obtained on 25 February 1984 by Patricia A. Burrowes and B. del Castillo; KU 169267, female, from $8 \mathrm{~km}$ NE Pasto (3020 m), obtained on 24 September 1974 by William E. Duellman; KU 169268, female, from $8 \mathrm{~km}$ NE of Pasto (3050 m), obtained on 21 May 1975 by William E. Duellman; KU 169269335, 169341, QCAZ 24467-71 (10 females, 61 males, 1 juvenile), from $12 \mathrm{~km}$ E of Pasto (3050 m), obtained on 24 September 1974 by William E. Duellman, Linda Trueb, Dana T. Duellman, and John E. Simmons, and on 2 October 1974 by William E. Duellman and John E. Simmons; KU 200239, female, from $12.8 \mathrm{~km}$ NE of Pasto $(3020 \mathrm{~m}$ ), obtained on 25 February 1984 by Benjamín del Castillo; KU 154583, adult gravid female, from crest between Pasto and Laguna La Cocha, on road to Laguna La Cocha (3150 m), obtained on 2 August 1965 by R. E. Smalley; KU 200219-38 (19 females, 1 male), from El Tabano,16 km E of Pasto (3280 m), 
obtained on 25 February 1984 by Patricia A. Burrowes and Benjamín del Castillo; KU 169262-66, 5 females, from north shore of Laguna La Cocha, $(2790 \mathrm{~m})$, obtained on 2 October 1974 by John E. Simmons and Linda Trueb; ICN 3406, female, from Volcán Galeras (Hacienda San Gerardo), obtained on August 1977 by Santiago Díaz; ICN 3633, 3636-38, 4 females, from El Encano (2800 m), obtained on December 1977 by L. Gómez; ICN 450, 459, 469, 471-73, 481 (3 females, 4 males), from El Encano (2800 m), obtained on 19 January 1971 by Nancy Bastidas.

Diagnosis. (1) A species with mean SVL in adult females $46.7 \mathrm{~mm}(40.3-52.2, \mathrm{SD}=2.852, n=48)$ and in adult males $38.6 \mathrm{~mm}(34.7-41.8, \mathrm{SD}=1.428, n=76)$; (2) hind limbs short, tibia length/SVL 0.302-0.406 $(n=$ 121); (3) phalangeal formula of hand 2-2-3-3, webbing absent; (4) foot webbing formula $\mathbf{I}\left(0^{+}-1^{-}\right)-(1 / 2-2-$

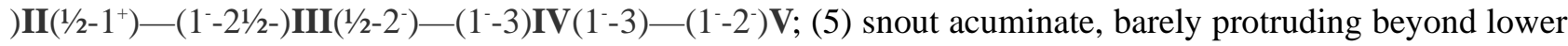
jaw; (6) tympanic membrane and tympanic annulus absent; (7) dorsal surfaces of body smooth, bearing spiculae and coni mostly on sacral region, (8) black spiculae and coni (gray in preservative) present on flanks; (9) vertebral neural processes inconspicuous; (10) dorsum orange-red to black (pale creamy brown to black in preservative); (11) minute gray stippling present on dorsum of body; (12) venter orange to orange-red and dull yellow (cream in preservative); (13) gular region with a patch of black spiculae on gular-chest region in females (but see sexual dimorphism variation).

By displaying in life either orange-red, or black or a combination of both colors, Atelopus ardila sp. nov. is most similar to A. guanujo Coloma (some individuals orange-red), A. bomolochos Peters (some individuals orange-red), A. sorianoi (orange-red), A. sp. 6 (some individuals orange, Rueda-Almonacid and Acosta 2005), A. ebenoides Rivero (black), A. nanay Coloma (black), A. marinkellei Cochran and Goin (black), A. guitarraensis Osorno-Muñoz, Ardila-Robayo, and Ruiz-Carranza (some individuals black), A. pastuso sp. nov. (some individuals black), A. patazensis Venegas, Catenazzi, Siu-Ting, and Carrillo (orange and black), A. podocarpus sp. nov. (black), A. carrikeri Ruthven (black to orange and yellow), and A. ignescens (black). Nonetheless, by having a patch of black spiculae on females' gular-chest region, A. ardila is distinct from all of them, except A. ignescens, A. carrikeri, and potentially A. sp. 6 (presence and characteristics of gular patch unknown). It differs from the latter by lacking a dark brown dorsal pattern. It differs from A. ignescens in SVL, foot and tibia length, and sacrum width (see below), and by nearly lacking posterolateral process on hyoid plate (well developed in A. ignescens). It differs from A. carrikeri in size and by having minute gray stippling on dorsum of body (absent in A. carrikeri); A. ardila (mean SVL of females 46.7; $\mathrm{SD}=2.852, n=$ 48 ) is significantly smaller than $A$. carrikeri (mean SVL of females $57.0, \mathrm{SD}=4.153, n=4$; data from Coloma 1997) (SVL of females $t$-test, $t=6.7175, \mathrm{df}=50, P<0.0001$ ).

Herein, we compare SVL and 8 morphological variables of Atelopus ardila vs A. ignescens (see materials and methods). Three axes of the PCA accounted for $58 \%$ of the total variation (Table 1). PC I mainly

TABLE 1. Eigenvalues, character loading and percentage of explained variance for principal components (PC) I-III for eight morphometric variables of Atelopus ardila vs A. ignescens. Abbreviations are: SVL = snout-vent length; TIBL $=$ tibia length; FOOT $=$ foot length; HLSQ= head length; HDWD = head width; EYNO = eye-nostril distance; ITNA = Internarial distance; RDUL = radio-ulna length; SW = sacrum width.

\begin{tabular}{lrrr}
\hline Variable & PC I & PC II & PC III \\
\hline Log SVL & 0.00000 & -0.00000 & 1.00000 \\
Residuals TIBL & 0.50815 & 0.09575 & -0.00000 \\
Residuals HLSQ & 0.43768 & -0.26860 & 0.00000 \\
Residuals HDWD & 0.31595 & -0.05531 & 0.00000 \\
Residuals ITNA & 0.04993 & 0.55033 & -0.00000 \\
Residuals THBL & 0.09394 & 0.45684 & 0.00000 \\
Residuals RDUL & 0.45037 & -0.00874 & -0.00000 \\
Residuals FOOT & 0.47875 & -0.06910 & -0.00000 \\
Residuals SW & 0.08388 & 0.63183 & -0.00000 \\
Percent \% & 29.933 & 16.519 & 11.111 \\
\hline
\end{tabular}


included tibia, foot, and radio ulna lengths, which are the highest loadings along this axis; in which most $A$. ardila individuals tended to have larger tibia, feet and forearms (Fig. 2). PC II mainly included sacrum width and internarial distance, whereas in PC III the highest loading was SVL. Although there is some overlap of the morphometric space of $A$. ardila $v s$ A. ignescens (Fig. 3), significant separation occurred along two axes [overall: $\left.\mathrm{F}_{3}\right)=43.854, \mathrm{P}<0.001 ; \mathrm{PC} 1: \mathrm{F}\left({ }_{1}\right)=59.183, \mathrm{P}<0.001 ; \mathrm{PC} 2: \mathrm{F}\left({ }_{1}\right)=31.380, \mathrm{P}=0.009 ; \mathrm{PC} 3: \mathrm{F}\left({ }_{1}\right)=$ $0.990, \mathrm{P}=0.321]$.

Description of holotype. (Figs. 1A-C, virtual animation). Head about as long as wide, HLSQ and HDWD less than one third SVL (HLSQ/SVL $=0.260, \mathrm{HDWD} / \mathrm{SVL}=0.256$ ); snout acuminate, its margin rounded in dorsal view; profile of tip of snout in lateral view curved and barely protruding to the anterior margin of jaw; no swollen gland on tip of snout; nostrils slightly protuberant, directed laterally, situated posterior to level of apex of lower jaw; canthus rostralis distinct, nearly straight from eye to nostril; loreal region concave; lips slightly flared; interorbital and occipital regions flat, smooth; eyelid flared without tubercles; postorbital crest flared, not glandular; postorbital, pretympanic and post-tympanic areas bearing coni; tympanic membrane and tympanic annulus absent; choanae small, rounded, widely separated (30.3\% of HW); tongue about twice as long as wide, its posterior half not attached to floor of mouth.

Forearm relatively short $(\mathrm{RDUL} / \mathrm{SVL}=0.271)$; palmar tubercle round; thenar, supernumerary palmar, and subarticular tubercles distinct; digital tips with round pads; thumb relatively long $(\mathrm{THBL} / \mathrm{HAND}=$ 0.611), apparently having two phalanges; webbing on hands absent, fingers lacking lateral fringes; relative length of fingers II $<\mathrm{III}<\mathrm{V}<\mathrm{IV}$. Tibia relatively short (TIBL/SVL $=0.323$ ); fold on distal half of inner edge of tarsus absent; inner and outer metatarsal tubercles round-oval, distinct, about the same size; supernumerary plantar and subarticular tubercles conspicuous, low raised; digital pads distinct; webbing formula of foot $\mathbf{I}\left(0^{+}\right)-(1 / 2) \mathbf{I I}(1 / 2)-\left(1^{-}\right) \mathbf{I I I}(1 / 2)-\left(1^{-}\right) \mathbf{I V}\left(0^{+}-1 / 2\right)-(1) \mathbf{V}$; relative length of toes $\mathrm{I}<\mathrm{II}<\mathrm{III}=\mathrm{V}<\mathrm{IV}$.

Dorsal surfaces mostly smooth, except dorsum of arms, thighs, and sacral region, which are covered by coni; flanks with abundant coni; ventral regions weakly aerolate, except venter of forearm, foot and tarsi; an inverted triangle-shaped patch of spiculae and coni on gular-chest region; cloacal opening a tube at nearly midlevel of thighs, directed posteriorly; rugose skin lateral to cloacal opening, low warts, spiculae and coni at posterior thighs.

In preservative ( $70 \%$ ethanol), dorsum of body and limbs brown with gray coni; thin brown line along middorsum from tip of snout to cloacal region; loreal region brown; flanks cream with gray coni; ventral surfaces cream, except slightly darker cream distally on fingers and toes; minute gray stippling on dorsum of body (viewed under a dissecting microscope); spiculae and coni on gular-chest region brown; proximal end of tongue lacking black pigmentation.

Measurements of holotype (mm). SVL 47.3, TIBL 15.3, FOOT 20.4, HLSQ 12.3, HDWD 12.1, ITNR 4.6, EYDM 3.6, EYNO 2.7, RDUL 12.8, HAND 12.6, THBL 7.7, SW 13.5.

Variation. Meristic variation is given in Table 2. A juvenile female (KU 169341, SVL $=21.3 \mathrm{~mm}$ ) possesses abundant spiculae and coni on the dorsum and flanks, but lacks spiculae on gular-chest region. It differs from adults by having cream flanks in contrast to gray dorsum.

The paratypes resemble the holotype with the following noteworthy exceptions. Females are larger than males (Table 2). Males have vocal slits and keratinized nuptial pads variably extensive on the dorsal and inner surfaces of the thumb (= Finger II) and Finger III. The forelimbs are relatively long and slender only in females, but they are short with a stout muscular area in males (Table 2); there are significant differences in RDUL between males and females (RDUL Student's $t$-test, $t=11.4579$, df $=106, P<0.0001$ ). Males lack coni, whereas females have a greater density of spiculae and coni. Females possess an inverted triangular patch of spiculae and coni on the gular-chest region; however, three topotypic females lack spiculae there, whereas in 10 males (out of 61) from $12 \mathrm{~km}$ east of Pasto a patch of scattered spiculae is present on gularchest region, or spiculae are nearly absent.

Color variation in preservative ( $70 \%$ ethanol): Topotypic specimens and one from a nearby site (KU 169268) (4 females, 7 males) are similar to the holotype. Dorsal color generally varies from pale creamy brown (KU 200217) to dark brown (KU 200212); spiculae and coni vary from dark brown to black. A male (KU200216) has dark brown marbling on the dorsum, and stripes at joints on the tarsi, feet and hands. The 
venter is uniform cream in all individuals. A thin brown line along middorsum varies from conspicuous (KU 200207) to barely visible (KU200217).

\section{A}
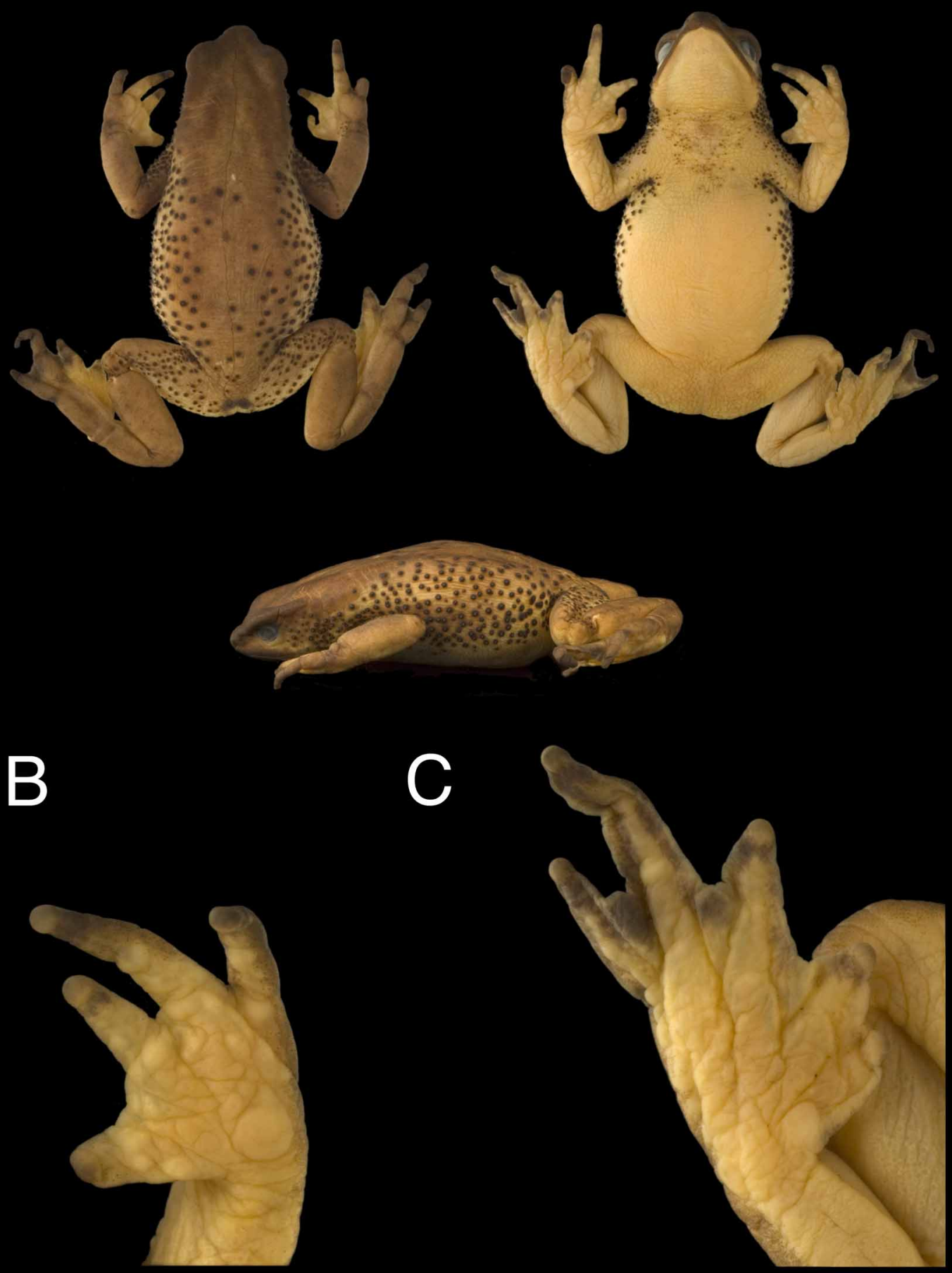

FIGURE 1.-Holotype of Atelopus ardila (KU 200214): (A) adult female, SVL = $47.3 \mathrm{~mm}$; (B) ventral view of right hand, enlarged 3.5 times of $\mathrm{A}$; $(\mathrm{C})$ ventral view of right foot; enlarged 3.2 times of $\mathrm{A}$. 
TABLE 2. Meristic variation of Atelopus ardila. Mean \pm one SD, and range are given. Abbreviations are: SVL $=$ snoutvent length; TIBL = tibia length; FOOT = foot length; HLSQ= head length; HDWD = head width; EYDM = eye diameter; $\mathrm{EYNO}=$ eye-nostril distance; ITNA = Internarial distance; $\mathrm{RDUL}=$ radio-ulna length; $\mathrm{THBL}=$ thumb length; $\mathrm{SW}=$ sacrum width. All measurements are in $\mathrm{mm}$.

\begin{tabular}{|c|c|c|}
\hline \multicolumn{3}{|c|}{$\begin{array}{c}\text { Atelopus ardila } \\
\text { Pasto-Cocha }\end{array}$} \\
\hline & Males $(n=76)$ & Females $(n=48)$ \\
\hline SVL & $\begin{array}{l}38.6 \pm 1.43 \\
(34.7-41.8)\end{array}$ & $\begin{array}{l}46.52 \pm 2.85 \\
(40.3-52.2)\end{array}$ \\
\hline TIBL & $\begin{array}{l}14.41 \pm 0.58 \\
(13.2-16)(n=73)\end{array}$ & $\begin{array}{l}15.91 \pm 0.81 \\
(13.6-17.8)\end{array}$ \\
\hline FOOT & $\begin{array}{l}16.68 \pm 0.91 \\
(14-18.7)(n=71)\end{array}$ & $\begin{array}{l}19.9 \pm 1.34 \\
(16-22)(n=40)\end{array}$ \\
\hline HLSQ & $\begin{array}{l}11.79 \pm 0.52 \\
(10.8-13.5)(n=73)\end{array}$ & $\begin{array}{l}12.68 \pm 0.62 \\
(11.1-14.1)\end{array}$ \\
\hline HDWD & $\begin{array}{l}11.44 \pm 0.47 \\
(10.4-12.6)(n=73)\end{array}$ & $\begin{array}{l}12.34 \pm 0.63 \\
(10.6-13.7)\end{array}$ \\
\hline ITNA & $\begin{array}{l}4.1 \pm 0.27 \\
(3.5-4.8)(n=72)\end{array}$ & $\begin{array}{l}4.43 \pm 0.3 \\
(3.6-5.1)(n=40)\end{array}$ \\
\hline RDUL & $\begin{array}{l}11.82 \pm 0.56 \\
(10.2-13.1)(n=70)\end{array}$ & $\begin{array}{l}13.31 \pm 0.78 \\
(12-16.4)(n=38)\end{array}$ \\
\hline THBL & $\begin{array}{l}6.72 \pm 0.42 \\
(5.9-8.1)(n=66)\end{array}$ & $\begin{array}{l}8.48 \pm 0.42 \\
(9.7-7.3)(n=40)\end{array}$ \\
\hline SW & $\begin{array}{l}10.48 \pm 0.62 \\
(9.2-12.1)(n=70)\end{array}$ & $\begin{array}{l}12.66 \pm 1.19 \\
(9-15.5)(n=44)\end{array}$ \\
\hline RDUL/SVL & $(0.28-0.34)(n=70)$ & $(0.26-0.34)(n=38)$ \\
\hline TIBL/SVL & $(0.33-0.41)(n=73)$ & $(0.30-0.38)$ \\
\hline HLSQ/SVL & $(0.28-0.34)(n=73)$ & $(0.24-0.32)$ \\
\hline HDWD/SVL & $(0.27-0.33)(n=73)$ & $(0.23-0.29)$ \\
\hline
\end{tabular}

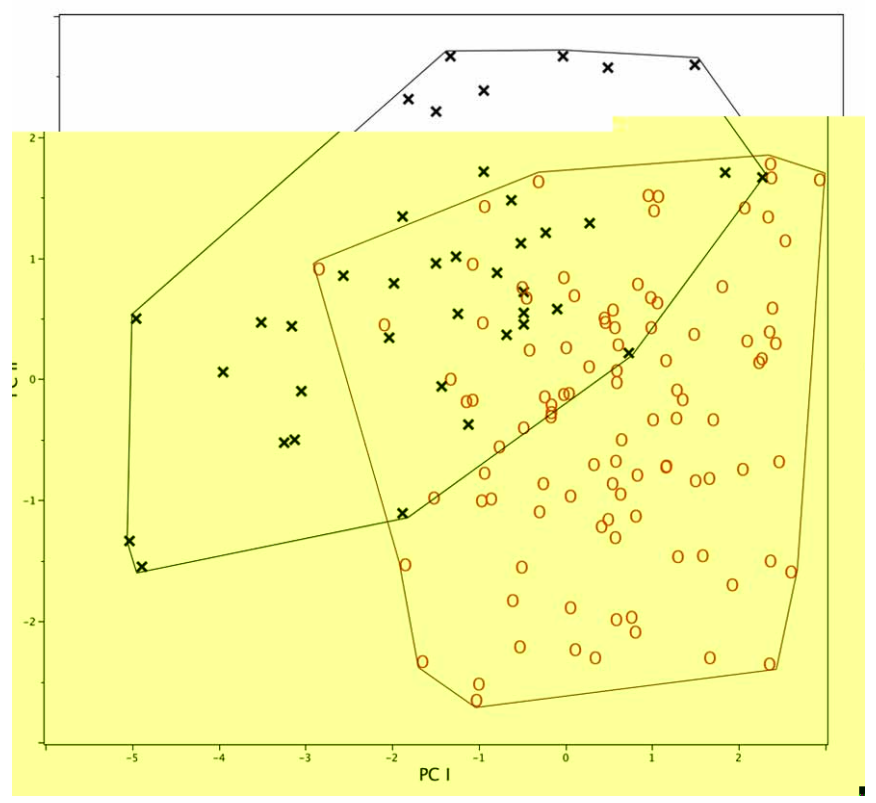

FIGURE 2.-Axes PC I and PC II from Principal Components Analysis based on eight size-corrected morphological variables for populations of Atelopus ardila and A. ignescens from Colombia and Ecuador. Circles $=$ A. ardila; $\mathrm{X}=$ A. ignescens. 


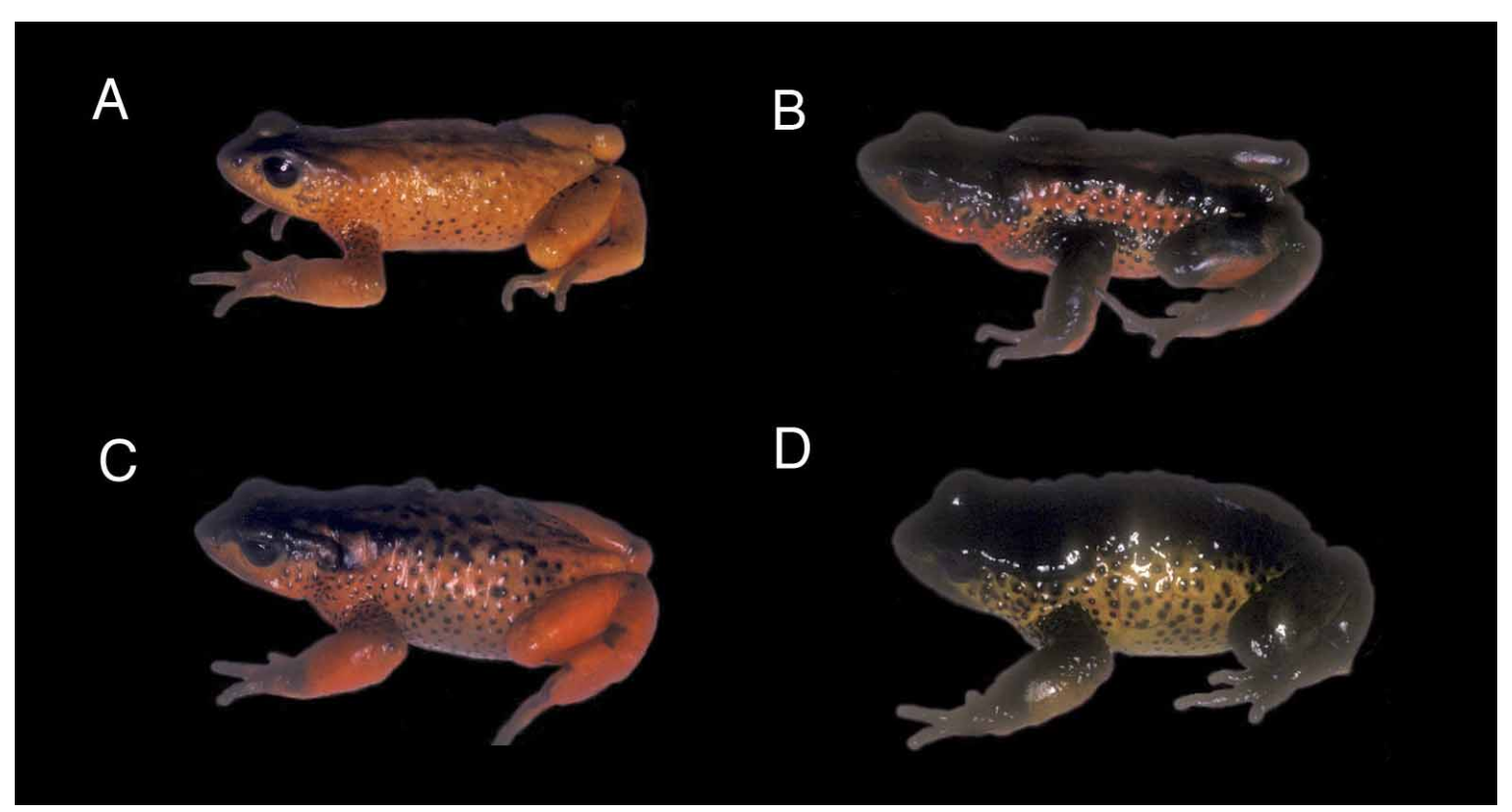

FIGURE 3.- Intrapopulation color variation of Atelopus ardila from $12 \mathrm{~km}$ E of Pasto, Departamento Nariño, Colombia: (A) KU 169270; (B) KU 169272; (C) KU 169271; (D) KU 169273 (Photos by WED).

Coloration in a series of specimens (KU 169269-335, 169341, 200239, QCAZ 24467-71) from 12.0-12.8 $\mathrm{km}$ east of Pasto (11 females, 61 males, 1 juvenile) varies from plain pale creamy brown (e.g., KU 169270) to plain black (e.g., KU 169322), or to a mosaic pattern of bold black marks (e.g., KU 169303). A narrow middorsal line varies from conspicuous (e.g., KU 169318) to absent (e.g., KU 169317) in males, whereas in females it is absent. The venter is uniform cream; however, in individuals that are darker dorsally the black color partially covers plantar and toe surfaces.

In a series of specimens (KU 200219-38) from $16 \mathrm{~km}$ E of Pasto (19 females, 1 male) the dorsum varies from deep black (12 specimens, e.g., KU 200235) to dark brown (e.g., KU 200232) to a mosaic pattern of black mottling (e.g., KU 200230). In 12 specimens the flanks are paler than the dorsum. In black individuals, the black invades the pelvic patch and the palmar and plantar surfaces, nearly entirely covering the latter, except for some of the tubercles (e.g., KU 200221).

In five females (KU 169262-66) from Laguna La Cocha the dorsum is mostly entirely black with diffuse dark brown mottling.

Color in life. (Figs. 3, 4A-B). The following is based on color slides taken by WED (CT 5932-34, 573542, 7211-12 of KU 169269-73, 169285-88, 200207-08, 200217), from WED field notes of 24 September and 2 October 1974, 21 May 1975, and from Patricia A. Burrowes' field notes of 25 February 1984. The dorsal ground color of the body and limbs varies from nearly entirely yellow and red-orange to black. Single individuals or series were described as follows: KU 200207-18 (from $7.5 \mathrm{~km}$ E Pasto, $2800 \mathrm{~m}$ ): red with or without black suffusion on snout and limbs; belly orange-red; flanks yellow with black lateral tubercles. KU 200239 (from 8 km NE Pasto, 3020 m): body yellow with black markings. KU 169267 (from 8 km NE Pasto, $3020 \mathrm{~m}$ ): dorsum orange-red with black-tipped tubercles, webbing pale orange, venter deep orange, iris dull brown with minute gold flecks. KU 169268 (from 8 km NE Pasto, $3020 \mathrm{~m}$ ): dorsum dull orange-red with black-tipped tubercles and brownish black head, venter orange. KU 169269-341 (from $12 \mathrm{~km}$ E Pasto, 3050 $\mathrm{m})$ : dorsal ground color varying from bright yellow-ochre to medium cadmium-orange and bright venetian red; dorsum plain with slight brownish suffusion and thin vertebral stripe and/or darker colored tubercles to spotted, mottled, or striped with sepia-umber (warm); venters plain with ground color; iris dull brown with minute bronze flecks. KU 200219-38 (from 16 km E Pasto, $3280 \mathrm{~m}$ ): black dorsally; venter orange to dull yellow. KU 169262-66 (from North shore Lago de la Cocha, 2790 m): dorsum black; venter red in KU 169262. 

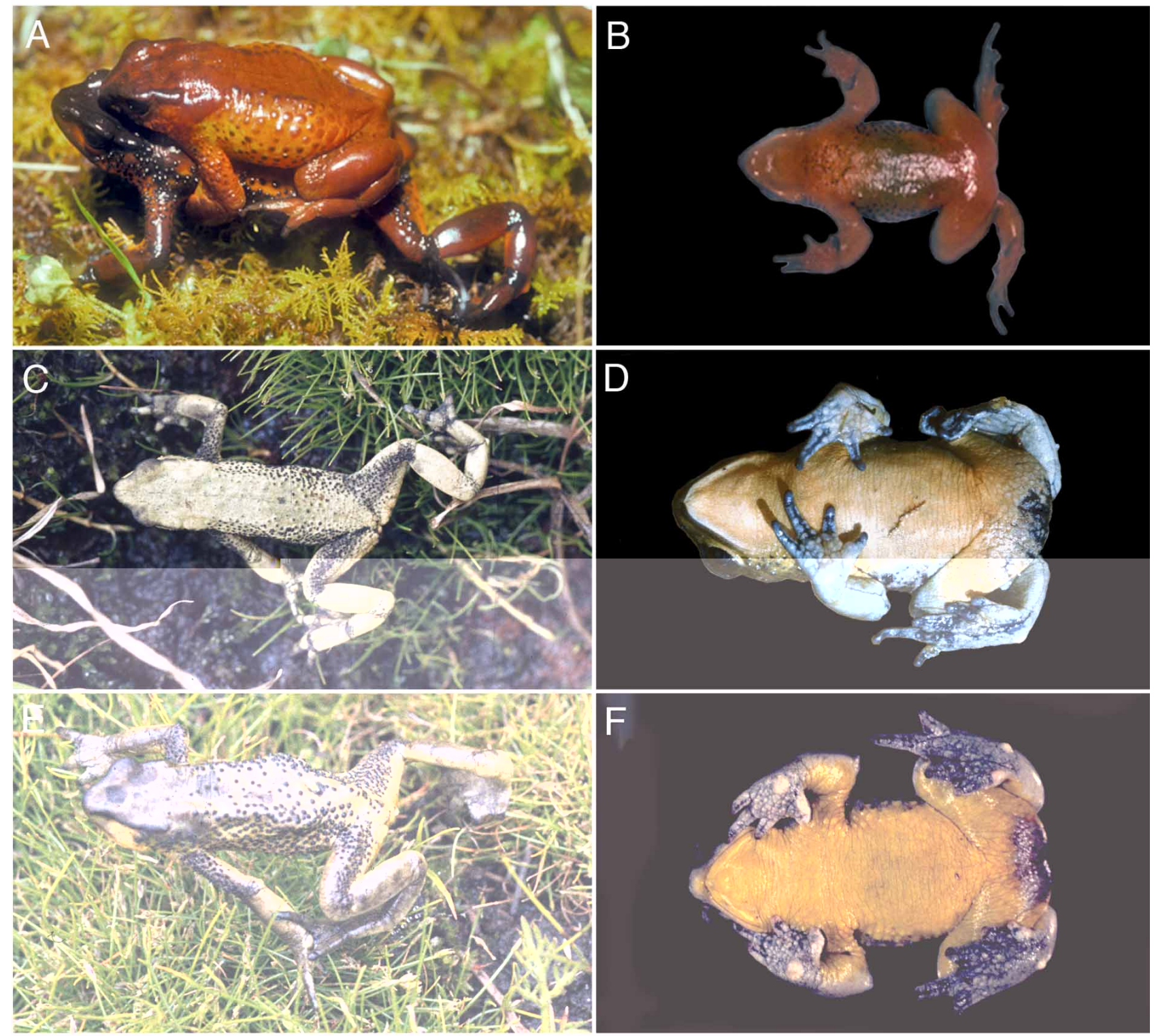

$\mathrm{G}$

$\mathrm{H}$
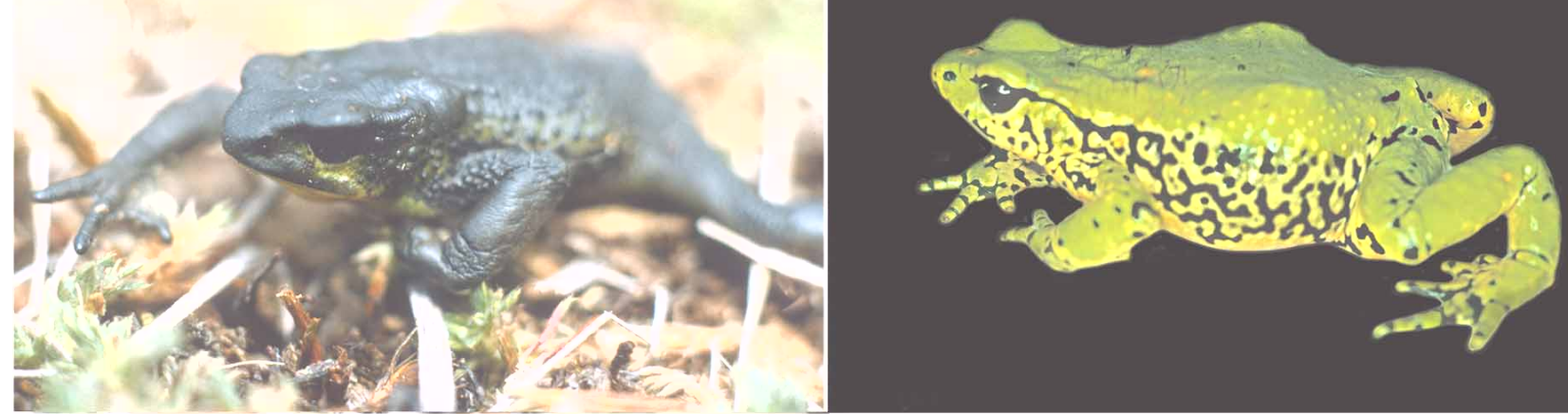

FIGURE 4.- (A, B) Atelopus ardila from $12 \mathrm{~km}$ E of Pasto, Departamento Nariño, Colombia (KU 169287-88, photos: WED); (C-D) Atelopus pastuso from Tulcán and 26,6 km W Tulcán, Provincia Carchi, Ecuador (MNHG 2258.68, QCAZ 1911, photos: LAC); (E-F) Atelopus pastuso from Tulcán and Cerro Cotacachi (MNHG 2258.65, QCAZ 15021 adult male, photos: LAC, Eugenia M. del Pino, respectively); (G) Atelopus pastuso from Hacienda La Esperanza (EPN 3244 adult female, photo: AA); (H) Atelopus angelito from NE Maldonado (KU 3244 adult female, photo: John D. Lynch). 
Tadpoles. Gómez Castillo (1982) described tadpoles from the Río Pasto and tributaries (2600-3000m). Tadpoles in Gosner Stages 18-29 had total lengths of 12-21 mm. Gómez Castillo (1993) described and illustrated black tadpoles from several creeks around Lago La Cocha (= Lago Guamez). He remarked on their similarity to tadpoles of A. varius and A. ignescens described by Starret (1967) and Duellman and Lynch (1969) respectively.

Distribution, ecology, natural history, and conservation status. Atelopus ardila is known only from the type locality and surrounding areas between Volcán Galeras eastward to Laguna de la Cocha in the Pasto Massif of the Andean Cordillera in Departamento Nariño in southern Colombia. These localities are in subparamo and paramo 2800-3280 m above sea level. The area of its extent of known occurrence is about $51.3 \mathrm{~km}^{2}$ (Fig. 5). At the type locality, annual mean rainfall is $1388 \mathrm{~mm}$ and the annual mean temperature is $12^{\circ} \mathrm{C}$ (Hijmans et al. 2005). At the time of collection, individuals (KU 200207-18) were crawling along a grassy irrigation ditch; others (KU 200219-38) were crawling on black rocks in a subparamo area with a steep incline, orange soils, black loose rocks, bunch grasses, Baccharis, and lots of mosses; an amplectant pair (yellow male, red female) also was found (P.A. Burrowes field notes, 25 February 1984). KU 169268 was under a yucca stump by day in subparamo with dense woody bushes and bamboo (WED field notes, 21 May 1975). KU 169285341 were crawling on the ground (open, mossy, grassy) after a rain; some were under rocks by day. Others (KU 169262-66) were crawling across a road by day (WED field notes, 2 October 1974). A female (KU 169267) was under a rock by day (temperature: $7.5-13.0^{\circ} \mathrm{C}$; no rainfall) in a subparamo area with dense woody bushes and bamboo. Other individuals (KU 169269-84) were in a rocky stream, where most were under rocks at the edge of the streambed; a few individuals were crawling amidst rocks on the ground by day (WED field notes, 24 September 1974).

Del Castillo Ch. (1982) and Gómez Castillo (1982; 1993) provided data on the reproductive biology of individuals from several localities and at ex situ conditions. Del Castillo Ch. (1982) induced oviposition using hormones, described behavior, physiology and early development of individuals and eggs from El Encano (locality stated in Gómez Castillo 1993:169). Gómez Castillo (1982) also described courtship, mating and reproduction of individuals from El Encano, San Fernando, and 11 km N of Pasto. Gómez Castillo (1993) provided data on the reproductive biology of individuals from Laguna La Cocha and vicinity and reported additional descriptions of induced oviposition. Three types of calls of individuals from several populations from Departamento Nariño (presumably a mixture of A. ardila and A. pastuso) were briefly described by Gómez Castillo (1982:61), two of them as peeps and another as a trill. Before axillary amplexus, it was observed that the male walks or jumps over the female from behind or from the side. Two males embracing a female were observed after exposing several males to a female. Amplectant pairs were found throughout the year at El Encano, San Fernando, Veredas Motilón, and Santa Rosa (Gómez Castillo 1982; 1993). At El Encano a pair remained in amplexus for at least 22 days. Amplexus among pairs maintained in captivity lasted more than 23 months; in one of these cases a pair was in amplexus for more than 74 days, and the male remained in the amplectant position for two days after the female died. Amplectant pairs were observed on two occasions under water (about $25 \mathrm{~cm}$ below the surface)—one in October 1978 at El Encano, and another in May 1979 at San Fernando. Another amplectant pair was observed under water at Quebrada Funduyacu (Gómez Castillo 1993). Tadpoles have been found throughout the year, but they are less abundant in the summer from June to August. Tadpoles were found in clear, non-contaminated waters in mountain creeks, Laguna La Cocha, and the Río Pasto and tributaries, but they were not observed near human habitations in urban areas (Gómez Castillo 1982; 1993).

Gómez C. and Ramos O. (1982) and Gómez and Ramos O. (1982) analyzed the stomach content of 30 individuals of five populations (San Fernando, 2600 m; El Encano, 2850 m; Daza, 2800 m, Volcán Galeras, 3150 m; Colón-Mocoa, 2200 m) from Municipio de Pasto and Intendencia de Putumayo, presumably belonging to Atelopus ardila (under the name A. ignescens). No voucher specimens were indicated, but we assume that the specimens were $A$. ardila based on the localities, measurements and color description of the animals provided. They report the following diet: Diptera $38 \%$, Coleoptera $33.2 \%$, Hymenoptera $25.4 \%$, Lepidoptera and Homoptera in smaller proportions. Chrysomelidae (Coleoptera) were the most abundant prey (26.5\%), followed by Drosophilidae (Diptera), Pteromalidae (Hymenoptera), Braconidae (Hymenoptera), Anthomyiidae (Diptera), Muscidae (Diptera), and Tephritidae (Diptera). 


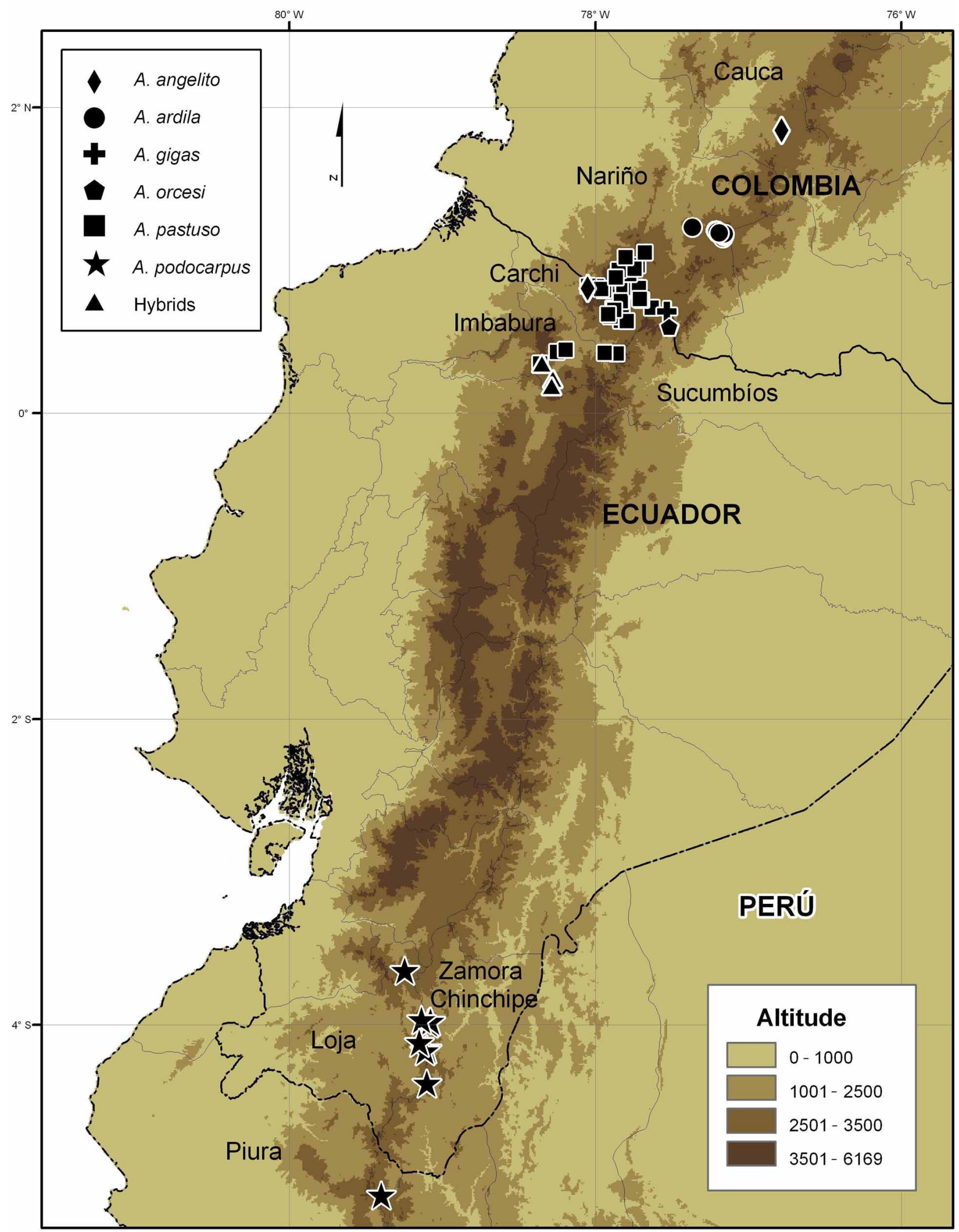

FIGURE 5.-Map of southern Colombia and northern Ecuador showing localities of Atelopus angelito, A. ardila, A. gigas, A. orcesi, A. pastuso and a population of hypothetical hybrids between A. pastuso and A. ignescens. Symbols for A. ardila indicate one or several close localities. 
Atelopus ardila is considered to be Critically Endangered (Possibly Extinct) (A2ace, IUCN Red List categories and criteria). The species is tagged as Possibly Extinct until further surveys confirm otherwise. The population has declined dramatically (more than $80 \%$ ) in the last two decades probably because of climate change and the impact of pathogens, which have affected many other montane species of Atelopus. No chytrid fungus reports or climate data for its area of distribution are available. The closest report of occurrence of the chytrid fungus is from Provincia Carchi near the Ecuador-Colombia border (Ron and Merino 2000). The risk factor of potential threat caused by the chytrid for anuran amphibian species calculated by Rödder et al. (2009:Fig. 2C) is high at the area of its distribution.

Although this species previously was abundant at several localities (Gómez Castillo, 1982:56), no individuals have been recorded (with voucher specimens) since June 1989 when one individual (IAvH 4767) was collected in Municipio Consacá at the surroundings of Volcán Galeras (Ardila-Robayo and Maldonado-Silva 2004). Intensive search efforts since the mid-1990s (Cepeda-Quilindo and Rueda-Almonacid 2005) revealed no individuals. Visual records indicate the presence of a few individuals in 1992 at Colón-La Rejoya in the Sibundoy Valley (Mueses-Cisneros, pers. com. 2009), and unconfirmed visual records by local people were made in 1994 and 2002 (Mueses-Cisneros, 2005). Intensive searches between December 2000 and February 2004 at 11 historical sites by Mueses-Cisneros (2005) resulted in no individuals.

Etymology. The specific name is a noun in apposition meant as patronym for Cristina Ardila-Robayo, a Colombian herpetologist of Instituto de Ciencias Naturales of the Universidad Nacional de Colombia. We recognize her dedication and valuable contributions to the Herpetology of Colombia. Part of her research efforts resulted in the description of 28 new species of amphibians from Colombia, including 10 Atelopus.

Remarks. Populations herein assigned to Atelopus ardila were excluded from the nominal taxon Atelopus ignescens by Gray (1983), Coloma et al. (2000), and Ron et al. (2003). Nonetheless, these populations were included temporarily under Atelopus ignescens (e.g., cited as Atelopus ignescens complex fide Gray 1983) by Lötters (1996); they were cited as Atelopus "complejo ignescens" by Ardila-Robayo and Maldonado-Silva (2004) and Cepeda Quilindo and Rueda Almonacid (2005). We provide morphological evidence that justifies the recognition of A. ardila as a different species. Nonetheless, as stated by Coloma et al. (2000), presumably A. ardila is the sister taxon of $A$. ignescens. Both species share a gular region having the unique presence of a patch of black spiculae in females. However, a phylogenetic analysis of the genus based on genetic markers is needed to enhance our current taxonomic understanding of these species.

\section{Atelopus gigas sp. nov.}

Holotype. KU 140320, adult female, from La Victoria, Departamento Nariño, Colombia, obtained in May 1970 by Kjell von Schneidern. According to John D. Lynch (in litt.) this locality is in Municipio de Ipiales, 38 $\mathrm{km}$ (by road) SE of Ipiales ( $\left.0^{\circ} 40^{\prime} \mathrm{N}, 77^{\circ} 32^{\prime} \mathrm{W} ; \sim 2700 \mathrm{~m}\right)$.

Paratypes. KU 140315-17, 140318 (cleared-and-stained adult female), 140319, 140321-29. Same data as holotype.

Diagnosis. (1) A large species with SVL in adult males 43.0-48.6 (mean $=45.6 \mathrm{~mm}, \mathrm{SD}=1.8082, n=6$ ), and in adult females 43.3-57.2 (mean $=53.8 \mathrm{~mm}, \mathrm{SD}=4.3232, n=9)$; (2) hind limbs short, tibia length/SVL $0.346-0.413$ ( $n=15)$; (3) phalangeal formula of hand 2-2-3-3, basal webbing absent; (4) foot webbing for-

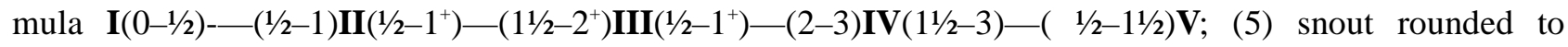
acuminate in dorsal view, slightly protruding beyond lower jaw; (6) tympanic membrane, tympanic annulus, and stapes absent; (7) dorsal surfaces of body usually smooth, bearing few warts mostly in males; (8) warts present on forearm, flanks and dorsal surfaces of thighs and shanks; spiculae present on flanks of females; (9) vertebral neural processes inconspicuous; (10) dorsum yellowish cream to yellowish tan in preservative; (11) minute gray stippling absent on dorsum of body; (12) venter cream in preservative; (13) gular region without warts, spiculae or coni.

In having a plain yellowish cream to yellowish tan dorsum in preservative, Atelopus gigas sp. nov. is most similar to A. guanujo, A. bomolochos (populations from Cutchil, Provincia Azuay, Ecuador), A. onorei 
Coloma, Lötters, Duellman, and Miranda-Leiva, A. ardila sp. nov. (some individuals), A. carbonerensis Rivero, A. chrysocorallus La Marca, and A. sorianoi from the Andes of Venezuela. Atelopus gigas (mean SVL of females 53.8; mean SVL of males 45.6) is significantly larger than A. guanujo (mean SVL of females 39.6; mean SVL of males 33.9). It differs from A. bomolochos and A. onorei in having coni and larger spiculae, and from A. bomolochos by lacking minute gray stippling (present in A. bomolochos). Atelopus gigas differs from A. ardila in females lacking a patch of spiculae and coni on the gular and pectoral regions (present in $A$. ardila), in having a nearly smooth dorsum (body smooth, bearing spiculae and coni mostly on sacral region in A. ardila), and by being significantly larger than A. ardila (mean SVL of females 46.7; mean SVL of males 38.6) (SVL of females Student's $t$-test, $t=6.090, \mathrm{df}=45, P<0.0001$; SVL of males Student's $t$-test, $t=$ 10.932 , df $=67, P<0.0001$ ). Atelopus gigas differs from A. carbonerensis and A. sorianoi in having a less protuberant snout and lacking a prominent postocular crest (postocular crest present in A. carbonerensis and A. sorianoi). Furthermore, it differs from A. carbonerensis and A. chrysocorallus by having vocal slits in males (absent in A. carbonerensis and A. chrysocorallus) and lacking a row of warts on the dorsolateral surfaces of the body in males (present in A. carbonerensis and A. chrysocorallus).

Description of holotype. (Figs. 6A-C). Head slightly longer than wide, HLSQ and HDWD less than one third SVL (HLSQ/SVL = 0.277, HDWD/SVL = 0.266); snout rounded in dorsal view; in lateral view, profile of tip of snout to the anterior margin of jaw nearly straight and slightly protuberant; swollen gland on tip of snout absent; nostrils slightly protuberant, directed laterally, situated at level slightly posterior to apex of lower jaw; canthus rostralis distinct, nearly straight from eye to nostril; loreal region concave; lips not flared; interorbital region and occiput flat, smooth; eyelid flared without distinct tubercles; postorbital crest slightly raised, glandular; pretympanic and tympanic areas free of warts; tympanic membrane and tympanic annulus absent; postmandibular and temporal area with warts; choanae small, rounded, widely separated; tongue twice as long as wide, broadest at anterior half, free along its posterior half.

Forearm relatively short $(\mathrm{RDUL} / \mathrm{SVL}=0.300)$; palmar tubercle round, poorly defined; supernumerary palmar tubercles distinct; thenar and subarticular tubercles low raised; digital tips with round pads; thumb relatively long (THBL/HAND = 0.779), apparently having two phalanges; webbing on hands absent, fingers having lateral keels that are more conspicuous on Finger IV; relative length of fingers II $<\mathrm{III}<\mathrm{V}<\mathrm{IV}$. Tibia relatively short (TIBL/SVL $=0.374)$; fold on distal half of inner edge of tarsus absent; inner metatarsal tubercle oval and flat; outer metatarsal tubercle round, slightly raised, about two thirds length of inner metatarsal tubercle; supernumerary plantar tubercles absent; subarticular tubercles flat, barely conspicuous; digital pads distinct; webbing formula of foot $\mathbf{I}\left(0^{+}\right)-(1 / 2) \mathbf{I}(1 / 2)-\left(1^{+}\right) \mathbf{I I I}(1)-\left(2^{+}\right) \mathbf{I} \mathbf{V}\left(2^{+}\right)-(1) \mathbf{V}$; relative length of toes $\mathrm{I}<\mathrm{II}<\mathrm{III}=\mathrm{V}<\mathrm{IV}$.

Dorsal surfaces smooth with scattered flat warts in posterolateral sacral region and on dorsal and posterior surfaces of thighs, increasing in number toward the flanks; warts on flanks and anterior and proximal upper anterior surfaces of forelimbs bear spiculae; each wart may lack or bear a single or a group (up to four) of spiculae; throat, chest, belly, undersides of limbs smooth; underside of arm rugose; cloaca opens as an inconspicuous tube at upper level of thighs, directed posteriorly; rugose margin of cloacal opening.

Color in preservative (70-75\% ethanol): dorsal surfaces of head and body pale yellowish cream, becoming pale yellowish tan posteriorly on body, flanks, and dorsal surfaces of limbs; margin of cloacal opening dark brown; minute gray stippling absent on dorsum of body (viewed at 8x magnification); warts and spiculae cream; dorsal surfaces of fingers vary from yellowish cream of inner finger and toe to yellowish tan towards outer fingers and toes; they bear a brown lines present at articular regions of phalanges, with the distal line being better defined than the rest; throat, chest, belly, and ventral surfaces of limbs uniform cream; outer metatarsal tubercle slightly lighter than adjacent areas; proximal end of tongue lacking black pigmentation, but lower lip bearing a poorly pigmented brown margin at distal end.

Measurements of holotype (mm). SVL 55.9, TIBL 20.9, FOOT 21.1, HLSQ 15.5, HDWD 14.9, ITNR 5.3, EYDM 5.8, EYNO 3.9, RDUL 16.8, HAND 13.6, THBL 10.6, SW 16.5.

Variation. Meristic variation is shown in Table 3. The paratypes resemble the holotype with the following noteworthy exceptions. There is variation in size, abundance and distribution of warts and spiculae. For example, a female (KU 140316) has more abundant warts and larger spiculae along dorsum and flanks than other 
females, whereas female KU 140317 has fewer warts and spiculae. Another female (KU 140317) has a more rugose plantar surface than other females. A juvenile female (KU 140321, SVL $=43.3$ ) has more warts and spiculae than other specimens. A female (KU 140317) has a shorter than normal and deformed Finger IV. Six males differ among them in that KU 140319, and 140324 possess more abundant warts on dorsum of sacral region, thighs and shanks.

TABLE 3. Meristic variation of Atelopus gigas. Mean \pm one SD, and range are given. Abbreviations follow Gray and Cannatella (1985) and Coloma et al. (2000). They are: SVL $=$ snout-vent length; TIBL $=$ tibia length; FOOT $=$ footh length; HLSQ= head length; HDWD = head width; EYDM = eye diameter; EYNO = eye-nostril distance; ITNA = Internarial distance; RDUL = radio-ulna length; $\mathrm{THBL}=$ thumb length; $\mathrm{SW}=$ sacrum width. All measurements are in $\mathrm{mm}$.

\begin{tabular}{|c|c|c|}
\hline \multicolumn{3}{|c|}{$\begin{array}{c}\text { Atelopus gigas } \\
\text { La Victoria }\end{array}$} \\
\hline & $\begin{array}{l}\text { Males } \\
(n=6)\end{array}$ & $\begin{array}{l}\text { Females } \\
(n=9)\end{array}$ \\
\hline SVL & $\begin{array}{l}45.56 \pm 1.81 \\
(43-48.6)\end{array}$ & $\begin{array}{l}53.4 \pm 4.32 \\
(43.3-57.2)\end{array}$ \\
\hline TIBL & $\begin{array}{l}17.16 \pm 0.39 \\
(16.6-17.8)\end{array}$ & $\begin{array}{l}19.94 \pm 0.89 \\
(17.9-20.9)\end{array}$ \\
\hline FOOT & $\begin{array}{l}17.35 \pm 1.06 \\
(15.7-18.8)\end{array}$ & $\begin{array}{l}20.36 \pm 1.3 \\
(17.6-21.7)\end{array}$ \\
\hline HLSQ & $\begin{array}{l}13.72 \pm 0.71 \\
(12.6-14.7)\end{array}$ & $\begin{array}{l}15.1 \pm 0.59 \\
(14.4-16.1)\end{array}$ \\
\hline HDWD & $\begin{array}{l}13.15 \pm 0.54 \\
(12.4-14)\end{array}$ & $\begin{array}{l}14.46 \pm 0.83 \\
(13-15.6)\end{array}$ \\
\hline ITNA & $\begin{array}{l}4.47 \pm 0.21 \\
(4.1-4.7)\end{array}$ & $\begin{array}{l}5.14 \pm 0.15 \\
(4.9-5.3)\end{array}$ \\
\hline RDUL & $\begin{array}{l}13.74 \pm 0.37 \\
(13.3-14.2)\end{array}$ & $\begin{array}{l}16.01 \pm 1.21 \\
(13.5-17.5)\end{array}$ \\
\hline THBL & $\begin{array}{l}7.29 \pm 0.36 \\
(7-7.8)\end{array}$ & $\begin{array}{l}9.49 \pm 0.75 \\
(8.4-10.6)\end{array}$ \\
\hline SW & $\begin{array}{l}14.49 \pm 0.89 \\
(13.4-15.7)\end{array}$ & $\begin{array}{l}17.43 \pm 1.54 \\
(14.5-19.4)\end{array}$ \\
\hline RDUL/SVL & $(0.27-0.32)$ & $(0.29-0.31)$ \\
\hline TIBL/SVL & $(0.35-0.39)$ & $(0.35-0.41)$ \\
\hline HLSQ/SVL & $(0.29-0.31)$ & $(0.26-0.34)$ \\
\hline HDWD/SVL & $(0.28-0.30)$ & $(0.25-0.30)$ \\
\hline
\end{tabular}

Sexual dimorphism is evident in that females are larger than males (Table 3). Males have vocal slits and keratinized nuptial pads on the dorsal and inner surfaces of the thumb and of Finger III, in which they are more abundant at the proximal phalanx. The forelimbs are relatively long and slender only in females, but they are short with a stout muscular area in males (Table 3); there are significant differences in RDUL between males and females (RDUL Student's $t$-test, $t=4.4105$, $\mathrm{df}=13, P<0.0007$ ). Males lack coni and nearly lack spiculae, whereas females have coni and spiculae.

All paratypes lack a brown area surrounding cloacal opening. In preservative, the dorsal coloration varies from uniform yellowish cream (KU 140321) to dark brown (KU 140319). One individual (KU 140318) has two dark brown bars across mid-dorsum of the body and a few, small diffuse dark brown marks on the dorsal surfaces of the hindlimbs. In one female (KU 140317), the lower lip is more pigmented with brown.

Color in life: Unknown. Presumably yellow or orange by comparison with coloration in ethanol of other preserved Atelopus. 

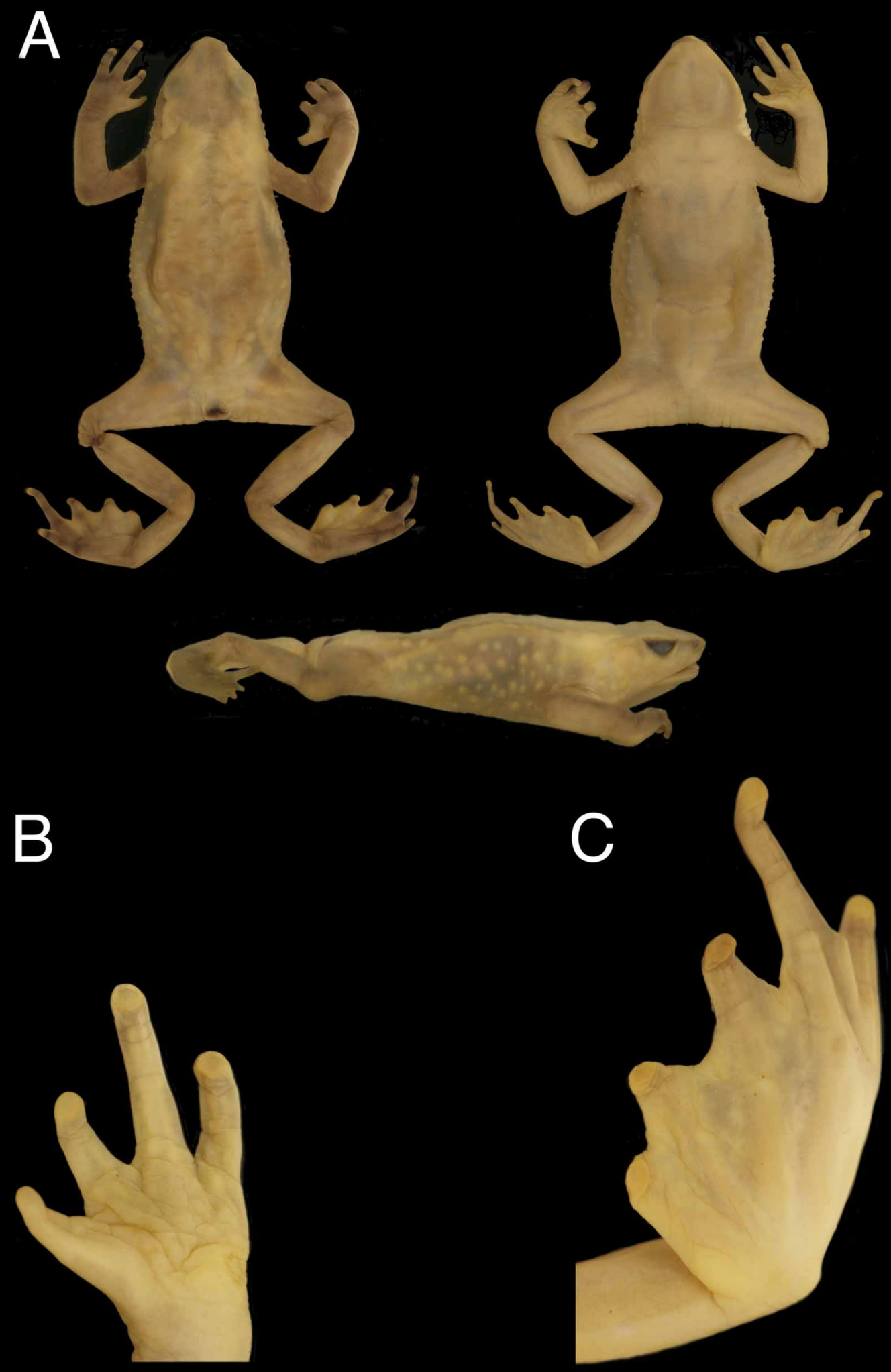

FIGURE 6.-Holotype of Atelopus gigas (KU 140320): (A) adult female, SVL = $55.9 \mathrm{~mm}$; (B) ventral view of right hand, enlarged 4.5 times of $\mathrm{A}$; (C) ventral view of left foot; enlarged 3.7 times of A. 
Tadpoles. Tadpoles of this species are unknown.

Distribution, natural history, and conservation status. Atelopus gigas is known only from the type locality (Fig. 5). This locality currently has cultivated areas. At La Victoria, annual mean rainfall is $1190 \mathrm{~mm}$ and the annual mean temperature is $13.3{ }^{\circ} \mathrm{C}$ (Hijmans et al. 2005). At time of collection, in May 1970, four out of seven adult females were gravid. One of them (KU 140318) contained 626 ovarian eggs of about $2.15 \mathrm{~mm}$ of diameter $(n=15, \mathrm{SD}=0.151)$. The stomach of KU 140318 contained remains of 63 arthropods [22 Coleoptera (1 Brenthidae, 7 Carabidae, 3 Curculionidae, 4 Staphylinidae, 7 undetermined), 13 Acari, 7 Hymenoptera, 4 Diptera, 1 Aracnida, 1 Blatodea, 1 Hemiptera, 1 Homoptera, 7 undetermined insects, 5 insect larvae], vegetal material, unidentified helminth endoparasites, and some undetermined material. The largest prey was an insect larva $7.1 \mathrm{~mm}$ long.

Atelopus gigas is considered as Data Deficient under IUCN Red List categories and criteria, because no collecting efforts have been carried out at its only known locality. Nonetheless, a similar fate of either severe decline or extinction (as most highland species of Atelopus) is a reasonable presumption. The chytrid fungus has been reported in very close proximity to the type locality in an Ecuadorian locality at Carchi Province (Ron and Merino 2000).The risk factor of potential threat caused by the chytrid for anuran amphibian species calculated by Rödder et al. (2009:Fig. 2C) is high at the area of its distribution.

Etymology. Gigas is a noun in apposition from the Greek word "gigas" that means giant. It is used in reference to the large size of this species, which is exceeded in size only by Atelopus boulengeri.

\section{Atelopus orcesi sp. nov.}

Holotype. MHNG 2684.75, adult gravid female, from La Alegría-Sibundoy ( $\left.0^{\circ} 34^{\prime} \mathrm{N}, 77^{\circ} 31^{\prime} \mathrm{W} ; 2400 \mathrm{~m}\right)$, Provincia de Sucumbíos, Ecuador, collected in May 1988, by Ana María Velasco.

Paratype. MHNG 2559.67, adult male with same data as holotype.

Diagnosis. (1) A medium-sized species with SVL in adult male $29.4 \mathrm{~mm}$ and in adult female $42.1 \mathrm{~mm}$; (2) hind limbs short, tibia length/SVL 0.354-0.415; (3) phalangeal formula of hand 2-2-3-3 (inferred), basal webbing absent; (4) foot webbing formula $\mathbf{I}\left(0-0^{+}\right)-(1 / 2-1) \mathbf{I}\left(0^{+}\right)-\left(1^{-}\right) \mathbf{I I}\left(1 / 2-1^{-}\right)-(1 / 2) \mathbf{I} \mathbf{V}(1 / 2)-(0-1 / 2) \mathbf{V}$; (5) snout acuminate, protruding beyond lower jaw; (6) tympanic membrane absent; (7) dorsal surfaces of body smooth, and warty on limbs; (8) row of yellow creamy warts on dorsolateral body of male, flanks with few, scattered, minute spiculae on female; (9) vertebral neural processes inconspicuous; (10) dorsum light to dark brown (in preservative), bearing a rudimentary X-shaped mark anteriorly and scattered small marks posteriorly; (11) minute gray stippling absent on dorsum of body, but minute white stippling present; (12) venter cream (in preservative) with a brown mark on gular-chest region; (13) gular region without warts, spiculae or coni.

Atelopus orcesi sp. nov. is distinct from most species of Atelopus by the combination of two features, i.e., bearing an X-shaped mark on anterior dorsum and by male having a conspicuous dorsolateral row of warts on the body. Only A. laetissimus Ruiz-Carranza, Ardila-Robayo, and Hernández-Camacho, A. mucubajiensis Rivero, A. nahumae Ruiz-Carranza, Ardila-Robayo, and Hernández-Camacho, A. pinangoi Rivero, and A. sanjosei Rivero and Serna, share these two features. Atelopus cruciger Lichtenstein and Martens and A. walkeri Rivero also have these features, but females of these species have a conspicuous dorsolateral row of warts on the body (absent in female A. orcesi).

Atelopus orcesi is mostly similar to two specimens (Atelopus sp. 16; Rueda-Almonacid 2005a) from Departamentos del Chocó and Valle from western Colombia. Although they are geographically separated and on opposite sides of the Andes, and they also differ by female of A. orcesi having a brown band on flank, the possibility that they are conspecific remains to be further investigated with a larger sample size. The morphological character that differentiates them might be polymorphic. Atelopus orcesi also is similar to A. nepiozomus Peters from Provincia Morona-Santiago in southeastern Ecuador. Both have a similar ventral color pattern. Atelopus orcesi is larger (female holotype SVL: A. orcesi $=42.1$ vs A. nepiozomus $=32.4$ ) and lacks warts on dorsum (many low, rounded warts and pustules, which may be spiculate in A. nepiozomus). 
Atelopus orcesi differs from Atelopus laetissimus, A. mucubajiensis, A. nahumae, and A. pinangoi by the contrasting color of the row of warts (not contrasting color in A. laetissimus, A. mucubajiensis, A. nahumae, and A. pinangoi), and by the female having a pale brown band on the flank (band on flank absent in A. laetissimus, A. mucubajiensis, and A. pinangoi). Furthermore, A. orcesi is geographically distant and geographically isolated from A. laetissimus and A. nahumae in the Sierra Nevada de Santa Marta in Colombia, and from A. mucubajiensis and A. pinangoi in the Sierra de Santo Domingo in the Cordillera de Mérida of the Venezuelan Andes. Atelopus orcesi differs from the smaller A. sanjosei (female SVL A. orcesi $=42.1 \mathrm{vs}$ females SVL A. sanjosei $=31.5-32.7 \mathrm{~mm}, n=2$ ) (from the eastern versant of Cordillera Central in Departamento Antioquia, Colombia) by female of $A$. orcesi lacking the dorsolateral row of warts (present in female A. sanjosei) and by having a brown mark on gular-chest region (absent in A. sanjosei).

Description of holotype. (Figs. 7A, 8A, 8C, 8D, virtual animation). Female. Head about as long as wide, HLSQ and HDWD less than one third SVL (HLSQ/SVL $=0.263, \mathrm{HDWD} / \mathrm{SVL}=0.256$ ); snout acuminate, its margin triangle-shaped with a round anterior vertex in dorsal view; profile of tip of snout in lateral view nearly straight and protuberant to the anterior margin of jaw; no swollen gland on tip of snout; nostrils slightly protuberant, directed laterally, situated posterior to level of apex of lower jaw; canthus rostralis distinct, weakly concave from eye to nostril; loreal region concave; lips slightly flared; interorbital and occipital regions flat, smooth; eyelid flared without tubercles; postorbital crest slightly raised, not glandular; low pretympanic and post-tympanic areas warty; tympanic membrane and tympanic annulus absent; temporal area smooth; choanae small, rounded, widely separated ( $29 \%$ of HW); tongue about twice as long as wide, its posterior half not attached to floor of mouth.

Forearm relatively short $(\mathrm{RDUL} / \mathrm{SVL}=0.264)$; palmar tubercle round; thenar tubercle nearly indistinct, supernumerary palmar and subarticular tubercles absent; digital tips with round pads; thumb relatively long (THBL/HAND = 0.615), apparently having two phalanges; webbing on hands absent, fingers lacking lateral fringes; relative length of fingers $\mathrm{II}<\mathrm{III}=\mathrm{V}<\mathrm{IV}$. Tibia relatively short $(\mathrm{TIBL} / \mathrm{SVL}=0.354)$; fold on distal half of inner edge of tarsus absent; inner metatarsal tubercle oval, distinct; outer metatarsal tubercle conical, low raised, about one third length of inner metatarsal tubercle; supernumerary plantar and subarticular tubercles absent; digital pads distinct; webbing formula of foot $\mathbf{I}\left(0^{+}\right)-\left(1^{-}\right) \mathbf{I}\left(0^{+}\right)-\left(1^{-}\right) \mathbf{I I I}(1 / 2)-(1 / 2) \mathbf{I V}(1 / 2)-(1 / 2) \mathbf{V}$; relative length of toes $\mathrm{I}<\mathrm{II}<\mathrm{III}=\mathrm{V}<\mathrm{IV}$.

Dorsal surfaces of body smooth; dorsal surfaces of limbs bearing small warts, except on hands and feet; warts present on temporal region and flanks with minute, scattered spiculae; anterior and upper surfaces of arms bearing spiculae; a single white, round, small, symmetrical tubercle on distal outer side of arm; throat, chest, belly, and undersides of hind limbs nearly smooth; cloacal opening a tube at upper level of thighs, directed posteriorly; rugose skin with few spicuale lateral to cloacal opening, and warty area at posterior, lower thighs.

In preservative ( $70 \%$ ethanol), dorsum of head, body, loreal and temporal regions mostly pale brown with a rudimentary (fragmented) X-shaped mark on head and suprascapular region, dorsum of body bearing three small dark brown marks; pale brown, oblique lateral band (bordered by a dark brown line) from temporal to inguinal regions, upper margin of band nearly straight and lower margin irregular; dorsal and ventral surfaces of limbs dark brown, with scattered darker or paler marks; minute white stippling present (gray stippling absent) on dorsum of body (viewed at maximum magnification with a dissecting microscope); tips of spiculae white; throat cream with a large brown mark extending to chest; belly, ventral surfaces of limbs, palms, soles mostly yellowish cream, except outer marginal parts covered by brown specially at tarsus and feet; pelvic patch distally covered by black mark; proximal end of tongue lacking black pigmentation, margin of maxillae with contrasting gray stripe.

Measurements of holotype (mm): SVL 42.1, TIBL 14.9, FOOT 14.4, HLSQ 11.1, HDWD 10.8, ITNR 4.3, EYDM 3.5, EYNO 2.6, RDUL 11.1, HAND 9.6, THBL 5.9, SW 12.4.

Variation. (Figs. 7B, 8B, virtual animation). The male paratype has the following measurements: SVL 29.4, TIBL 12.2, FOOT 11.5, HLSQ 9.5, HDWD 9.1, ITNR 3.5, EYDM 3.1, EYNO 2.5, RDUL 8.6, HAND 7.1, THBL 4.0, SW 9.0. The male paratype resembles the holotype with the following exceptions. Sexual dimorphism is evident in that it is smaller than the female. It has vocal slits and keratinized nuptial pads on the 
dorsal and inner surfaces of the thumb. Forelimbs are relatively long and slender in female. A tubercle is absent on the forearm of the male, which lacks spiculae on the flanks. The male bears a dorsolateral row of conspicuous warts from the suprascapular to the inguinal regions on the body (see discussion), and has a more protuberant snout, bearing a keeled tip.
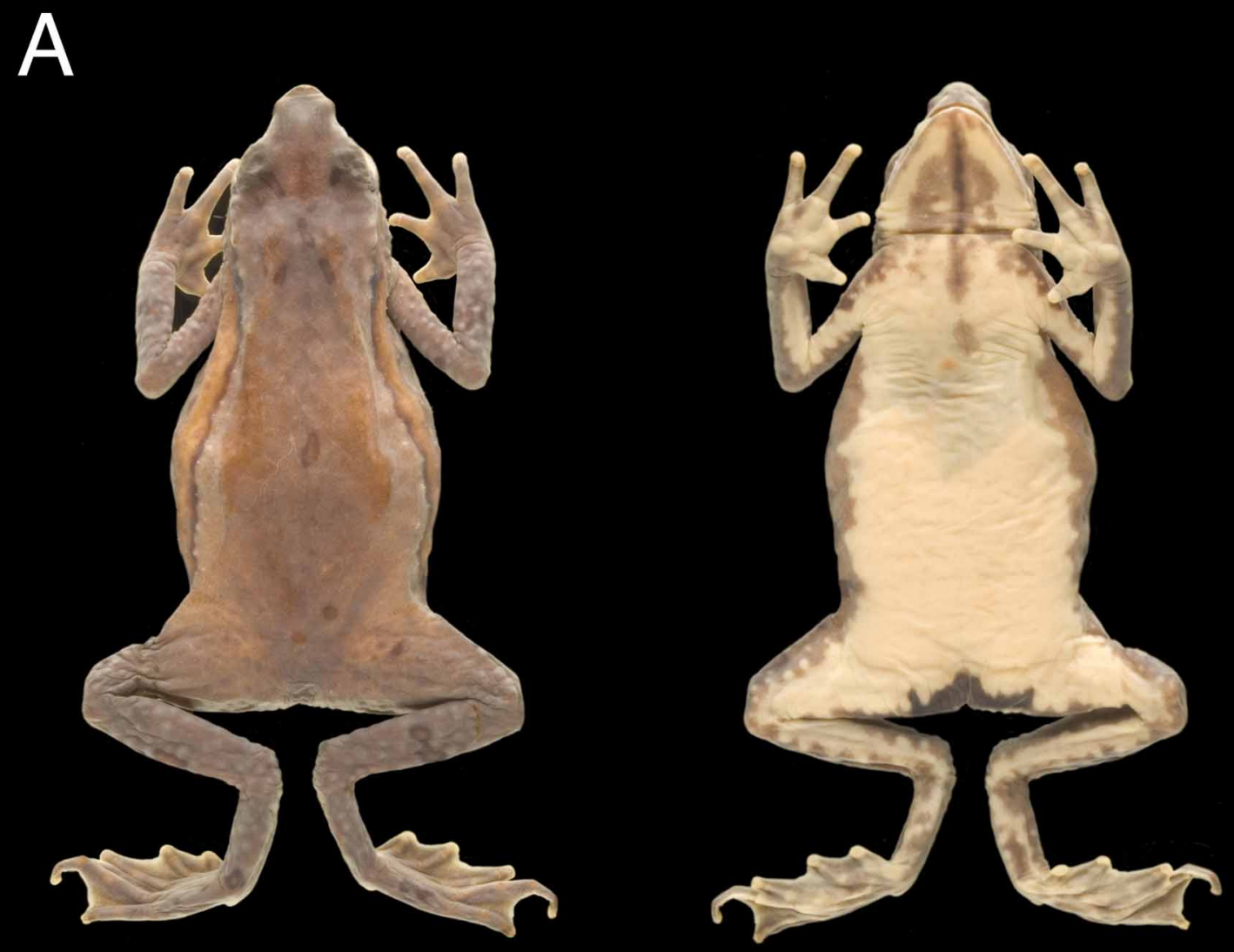

B
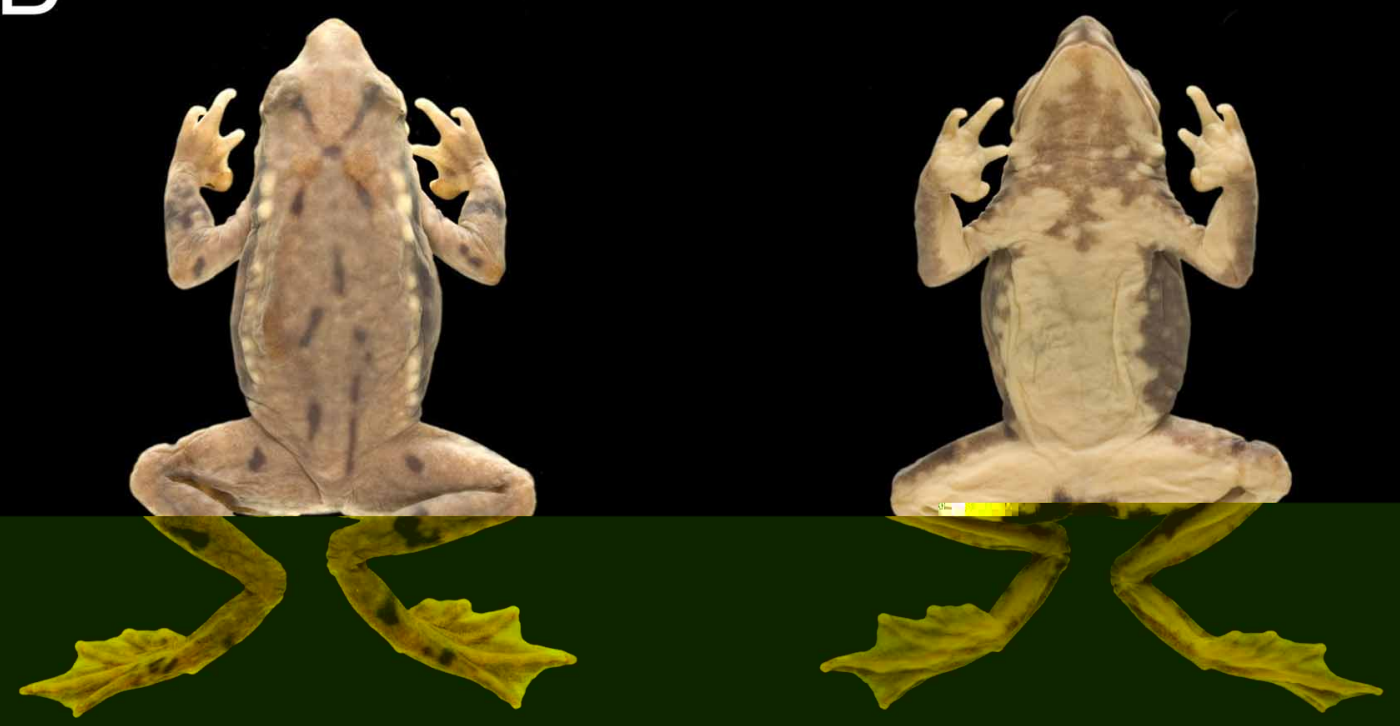

FIGURE 7.-Holotype and paratype of Atelopus orcesi (MHNG 2684.75, 2559.67, respectively): (A) adult female, $\mathrm{SVL}=42.1 \mathrm{~mm}$; (B) adult male, $\mathrm{SVL}=29.4 \mathrm{~mm}$. 


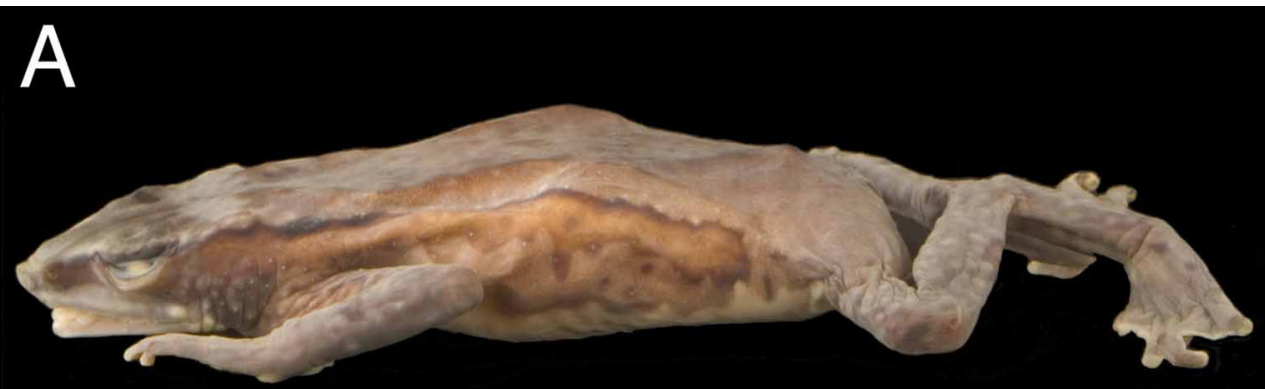

B

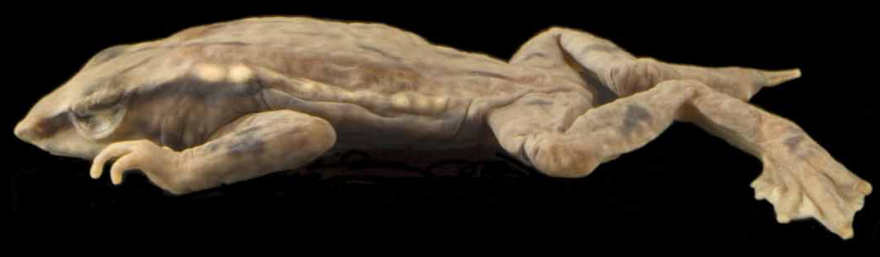

C
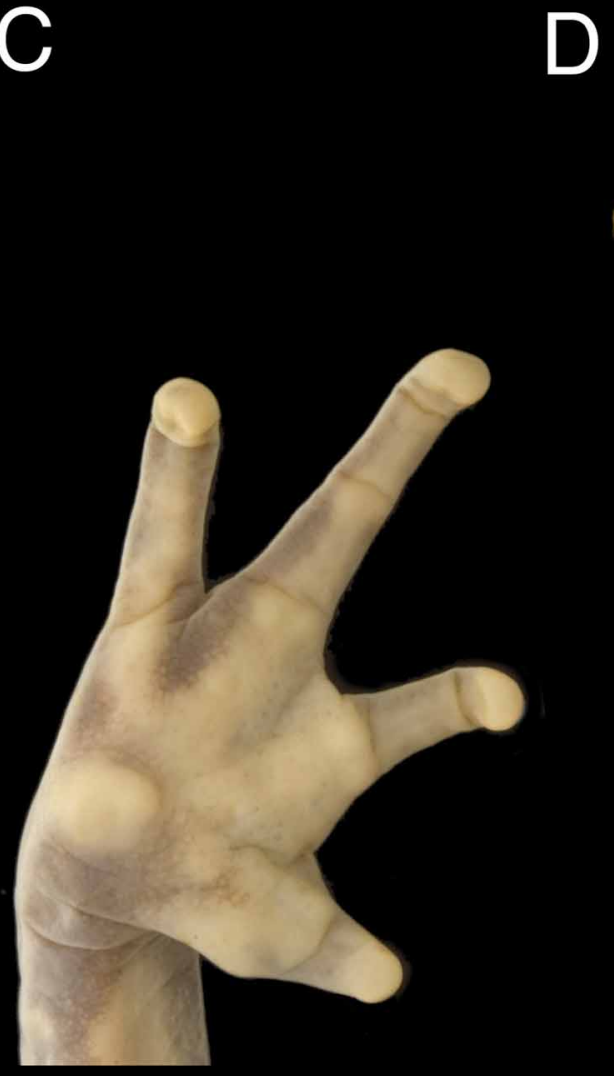

D

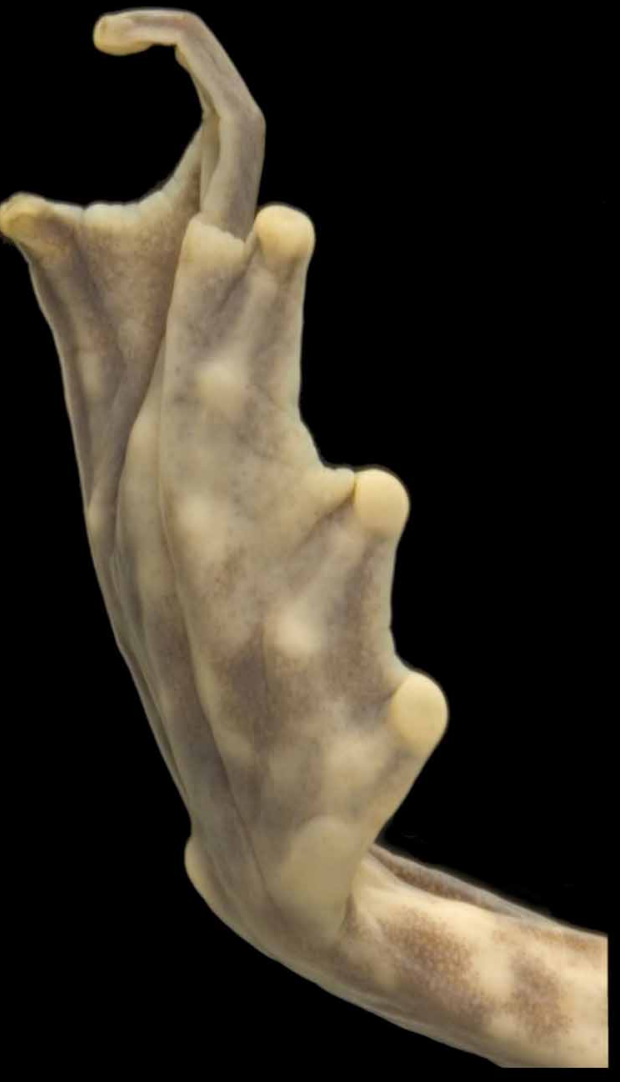

FIGURE 8.-Holotype and paratype of Atelopus orcesi (MHNG 2684.75, 2559.67, respectively): (A) lateral view of adult female; (B) lateral view of adult male; (C) ventral view of right hand, enlarged 4.2 times of A; (D) ventral view of left foot; enlarged 4.7 times of $\mathrm{A}$. 
Color variation in preservative ( $\sim 70 \%$ ethanol): The dorsum is paler than in the female. The $\mathrm{X}$-shaped mark on the head is more continuous, and there are more scattered marks on posterior dorsum. The marks are nearly black, and there is no defined band on the flanks.

Color in life. Unknown.

Tadpoles. Unknown.

Distribution, ecology and current population status. Atelopus orcesi is known only from the type locality on the eastern versant of Cordillera Oriental in Provincia Sucumbíos, Ecuador (Fig. 5). The type locality is at about $2400 \mathrm{~m}$ above sea level in Montane Cloud Forest (Valencia et al. 1999). At the type locality, annual mean temperature is $14.2{ }^{\circ} \mathrm{C}$ and annual mean precipitation is $1199 \mathrm{~mm}$ (Hijmans et al. 2005).

Atelopus orcesi is considered to be Critically Endangered (Possibly Extinct) (A2ace, IUCN Red List categories and criteria). The species is tagged as Possibly Extinct until further surveys confirm otherwise. The population probably declined dramatically (more than $80 \%$ ) in the last two decades because of climate change and the impact of pathogens, which have affected many other montane species of Atelopus. The amphibian chytrid fungus has been reported in very close proximity to the type locality near Santa Bárbara in Sucumbíos Province (= Carchi Province of Ron and Merino 2000). The risk factor of potential threat caused by the chytrid for anuran amphibian species calculated by Rödder et al. (2009:Fig. 2C) is high at the area of its distribution.

No individuals have been reported after its discovery in May 1988, despite at least one intensive search effort of about 40 person-hours at the type locality and surroundings at elevations of 2000-2800 m above sea level, in December 2009 by Elicio Tapia and Samael Padilla of QCAZ.

Etymology. The specific name is a noun in the genitive case and it is a patronym for Gustavo Edmundo Orcés Villagómez (1903-1999), a pioneer of Ecuadorian vertebrate zoological research (Albuja V. 2004; Adler 2007). We recognize his contributions as a mentor and professor of a generation of zoologists in Ecuador, among them, two of us (LAC and AA). The specific name also is in recognition to the Fundación Herpetológica Gustavo Orcés that through the Vivarium, initially leaded by Jean-Marc Touzet and Ana María Velasco (the latter a collector of this species), pioneered herpetological public exhibits in Ecuador since the 1980s.

\section{Atelopus pastuso sp. nov.}

Holotype. QCAZ 15013, adult gravid female, from near a lake in Voladero, Páramo de El Ángel (approx. $0^{\circ} 41^{\prime} \mathrm{N}, 77^{\circ} 53^{\prime} \mathrm{W}$; ca $3750 \mathrm{~m}$ ), Provincia Carchi, Ecuador, obtained on 12 January 1980 by Jaime Jaramillo.

Paratypes. QCAZ 15009-12, 15014-15 (2 females, 1 male, 3 juveniles), same data as holotype; EPN 3238 (1 juvenile) from Chiles, $5 \mathrm{~km} \mathrm{~W}$ from Lagunas Verdes on road from Tufiño to Maldonado, 3840m, Provincia Carchi, Ecuador, obtained on 8 February 1986 by Ana Almendáriz and Patricio Ponce; KU 117840-41 (juveniles) from Volcán Chiles, $10 \mathrm{~km}$ W Tufiño, obtained on 23 February 1968 by John D. Lynch; QCAZ 15018 (female) from San Gabriel, Provincia Carchi, obtained on 1 January 1980 by Rafael Narváez; KU 164754-57 (4 females), from 4.5 km E San Gabriel, obtained on 4 October 1974 by William E. Duellman and John E. Simmons; EPN 3239-55 (11 adult females, 2 adult males, 4 juveniles), from Espejo, Hacienda La Esperanza (NW of El Ángel), 3400 m, obtained on 12 February 1986 by Ana Almendáriz and Patricio Ponce; QCAZ 1051, 1053, 1908-15 (9 juveniles) from $26.6 \mathrm{~km} \mathrm{~W}$ of Tulcán, near the Volcán Chiles (on road from Tulcán to Maldonado), 3690 m, obtained on 8 June 1989 by Felipe Campos Y., Stella de la Torre, Diego Lombeida and Luis A. Coloma; KU 164759-164837, 164841-48, 166296-166300 from 20 km SW Tulcán, Páramo de El Ángel, 3350 m, obtained on 18 May 1975 by William E. Duellman, Linda Trueb, John E. Simmons, and Dana T. Duellman; KU 117842-73 from Quebrada de Piedras, 20 km SW Tulcán, obtained on 24 February 1968 by John D. Lynch; QCAZ 3742 (female) from $42 \mathrm{~km} \mathrm{~W}$ of Tulcán, Provincia Carchi, Ecuador, 3645 m, obtained on 3 March 1993 by Diego Lombeida and Luis A. Coloma; KU 202255-66 (2 females, 10 males) from $30 \mathrm{~km} \mathrm{SW}$ Tulcán, obtained on 26 February 1984 by David M. Hillis and John E. Simmons; KU 202267 (female) from 38 km SW Tulcán, obtained on 2 April 1984 by John E. Simmons; KU 117799-839, 178338 (30 females, 2 males, 3 juveniles) from Tulcán, Provincia Carchi, Ecuador, obtained on 22 and 23 February 1968 by John D. Lynch, except KU 178338 that was collected on 26 May 1977 by John D. Lynch; MHNG 2258.64-74, 2271.39-40, QCAZ 57-58 (12 females, 3 males) from Tulcán, Provincia Carchi, Ecuador, obtained on 5 April 1985 by Luis A. Coloma; KU 202254 (female) from 12 km E of junction Pan-American highway and El Carmelo road, obtained on 24 February 1984, by David M. Hillis. 
Referred specimens. From Departamento Nariño, Colombia: ICN 26549, 26558, 26560 from Hacienda Alsacia, Tuquerres, km 10 (by road, Tuquerres-Guachucal), obtained on 16 November 1982 by María C. Ardila and Pedro M. Ruiz; ICN 26570 26574, 26580 from Cumbal, km 8 (by road Cumbal to El Volcán), 3470 m, obtained on 16 November 1982 by María C. Ardila and Pedro M. Ruiz; ICN 26585-86 from Cumbal, km 10-11, (by road Cumbal to El Volcán), 3470-3500 m, obtained on 16 November 1982 by María C. Ardila and Pedro M. Ruiz; ICN 2807, 2817-19 from Cumbal, Vereda El Salado-Pueblo Viejo, obtained on February 1976 by Mario Fajardo; ICN 2822-24 from Cumbal, Laguna de Cumbal, obtained on February 1976 by Mario Fajardo; ICN 2835 from San José, Pueblo Viejo, Vereda El Salado, obtained on February 1976 by Mario Fajardo. From Ecuador: EPN 2195-2211, from Cordillera Troya (on the road to Tulcán), Provincia Carchi, obtained on October 1959 by Manuel Olalla; QCAZ 2678, from Monte Olivo, Provincia Carchi, 3000 m, obtained on 1 March 1991 by Giovanni Onore; MHNG 2385.12-13, 2385.15-30, 2385.32-43, from Pimampiro, Provincia de Imbabura, approx. 2100 m, obtained on August 1986 by Giovanni Onore; QCAZ 1501922, from Pimampiro, Provincia de Imbabura, approximately 2100 m, obtained on 13 November 1976 by Fernando Ortiz-Crespo and Luis Rodríguez; EPN 3312-13, from Laguna Cuicocha, Provincia de Imbabura, 3590 m, obtained on 26 January 1988 by Ana Almendáriz and Jhanira Regalado. See additional specimens under Remarks.

Diagnosis. (1) A medium-sized species with SVL in adult females $38.7(29.6-50.7, \mathrm{SD}=3.89, n=153)$ and in adult males $31.8(26.1-38.9, \mathrm{SD}=2.42, n=128)$; (2) hind limbs short, tibia length/SVL $0.29-0.41(n=$ 281); (3) phalangeal formula of hand 2-2-3-3, basal webbing absent; (4) foot webbing formula $\mathbf{I}(1 / 2)-\left(1^{-}-\right.$ 1)II $(1 / 2-1)-\left(1-2^{+}\right) \mathbf{I I I}\left(1-2^{-}\right)-\left(2-3 \frac{1}{2}\right) \mathbf{I V}\left(2-3^{+}\right)-\left(1 / 2-1 \frac{1 / 2}{2}\right) \mathbf{V}$; (5) snout rounded to acuminate, slightly protruding beyond lower jaw; (6) tympanic membrane, tympanic annulus and stapes absent; (7) dorsal surfaces of body usually smooth, bearing few warts in sacral region, (8) warts and spiculae (black in life) present on forearm, flanks and dorsal surfaces of thighs and shanks; (9) vertebral neural processes inconspicuous; (10) dorsum black to grayish green and bright green (black to dark gray to cream, some specimens bearing either a marbled dorsum with diffuse dark and clear marks or a dark brown dorsum with cream marks in preservative); (11) minute gray stippling present on dorsum of body, (12) venter green to yellowish green, bright yellow, and dull creamy white (uniform cream in preservative); (13) gular region without warts, spiculae or coni.

In having a black and blackish gray dorsum in preservative, Atelopus pastuso sp. nov. is most similar to $A$. ardila, A. bomolochos, A. boulengeri Peracca, A. carrikeri, A. ebenoides, A. ignescens, A. nanay, A. petersi Coloma, Lötters, Duellman and Miranda-Leiva, A. podocarpus sp. nov., and A. spp. (populations from Río Tililag, Corazón Chupa and Atillo, in Chimborazo province). Atelopus pastuso differs from A. bomolochos, A. spp. A. peruensis, and A. podocarpus by having gray spiculae (yellow in A. bomolochos, red in A. podocarpus, white in A. nanay and A. spp.). Atelopus pastuso differs from A. carrikeri, A. ignescens and A. ardila by lacking a patch of spiculae and coni on the gular and pectoral regions (present in A. carrikeri, A. ignescens and A. ardila) and by having green pigments on dorsum and flanks (absent in A. carrikeri, A. ignescens and A. ardila). Atelopus pastuso differs from A. boulengeri by being smaller. It differs from A. petersi by having green coloration and lacking dorsal and ventral color patterns (dorsum with yellow orange pattern to almost entirely black, venter yellow with or without black marks, or uniform orange to reddish orange in $A$. petersi). Atelopus pastuso differs from A. ebenoides by having green coloration (black with yellow and white marks in A. ebenoides). It differs from A. nanay (from the Cordillera Occidental in the southern Andes of Ecuador) by having numerous black spiculae on flanks (scattered white spiculae in A. nanay).

Description of holotype. (Figs. 9A-C, virtual animation). Gravid female with eggs visible through ventral skin. Head slightly longer than wide, HLSQ and HDWD less than one third SVL (HLSQ/SVL $=0.277$, $\mathrm{HDWD} / \mathrm{SVL}=0.253$ ); snout acuminate in dorsal view; in lateral view, profile of tip of snout to the anterior margin of jaw nearly straight and slightly protuberant; swollen gland on tip of snout absent; nostrils slightly protuberant, directed laterally, situated at level slightly posterior to apex of lower jaw; canthus rostralis distinct, flared, nearly straight from eye to nostril; loreal region concave; lips not flared; interorbital region and occiput flat, smooth; eyelid flared without distinct tubercles; postorbital region glandular; pretympanic and tympanic areas bearing spiculae; tympanic membrane and tympanic annulus absent; postmandibular and temporal area with spiculae; choanae small, rounded, widely separated; tongue twice as long as wide, about equal width along its length, free along its posterior third. 


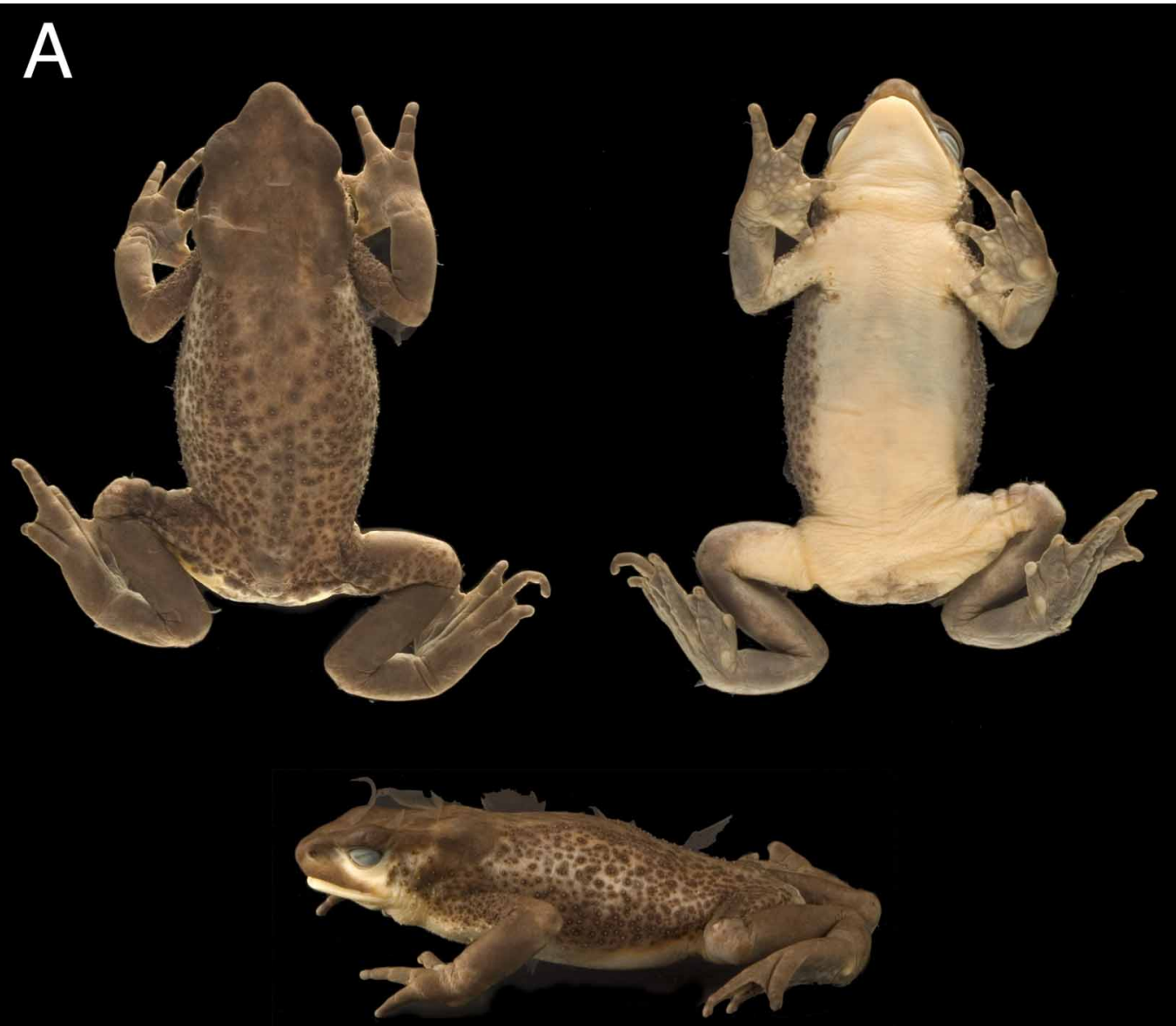

B
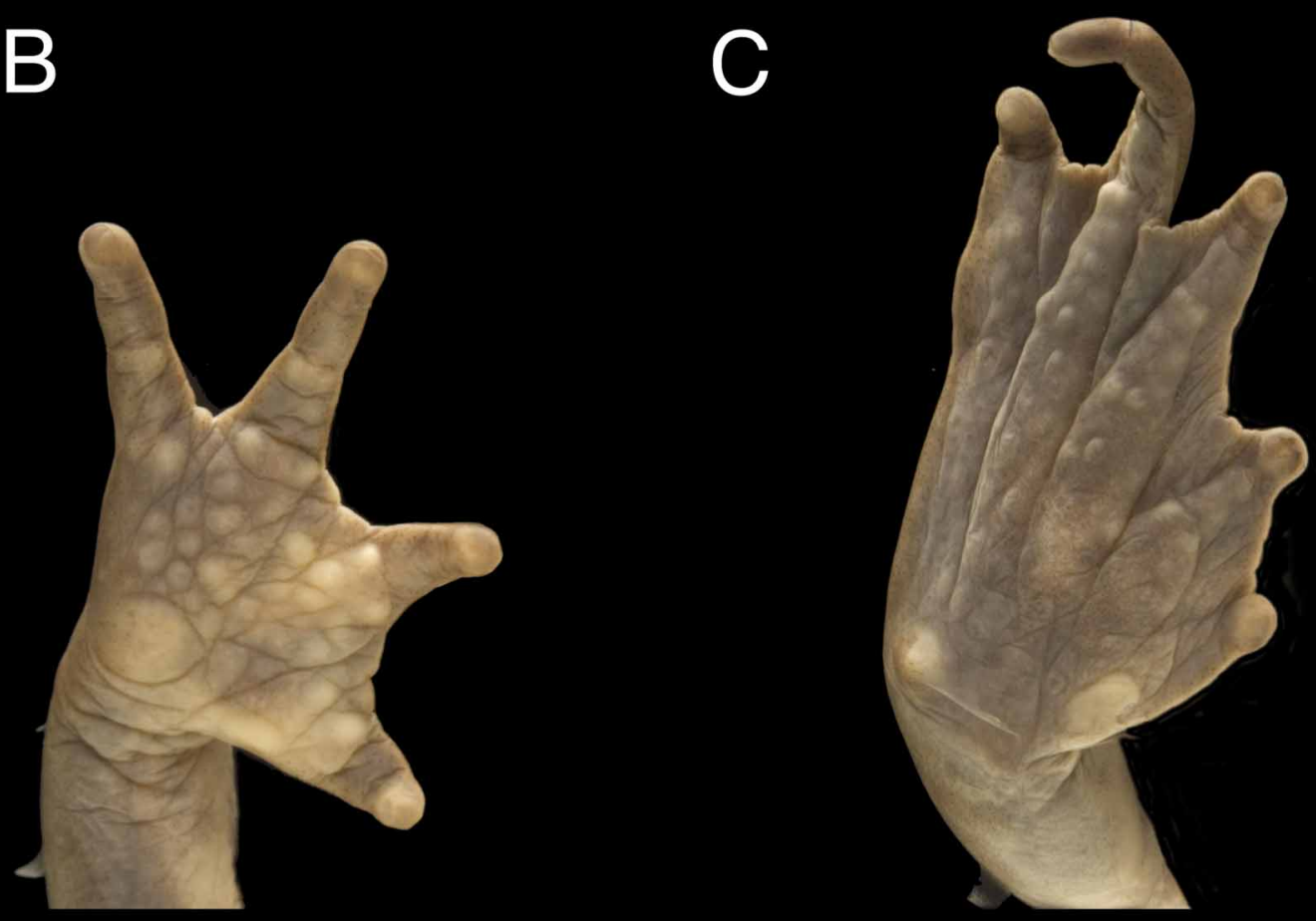

FIGURE 9.- Holotype of Atelopus pastuso (QCAZ 15013): (A) adult female, SVL = $41.8 \mathrm{~mm}$; molt visible in lateral view (B) ventral view of right hand, enlarged 3.9 times of A; (C) ventral view of left foot; enlarged 3.9 times of A. 
Forearm relatively short $(\mathrm{RDUL} / \mathrm{SVL}=0.268)$; palmar tubercle round, well defined; supernumerary palmar tubercles distinct; thenar and subarticular tubercles distinct, raised; digital tips with round pads; thumb relatively long (THBL/HAND $=0.702$ ), apparently having two phalanges; webbing on hands absent, fingers lacking lateral fringes or keels; relative length of fingers II $<\mathrm{III}<\mathrm{V}<\mathrm{IV}$. Tibia relatively short (TIBL/SVL $=$ 0.332); fold on distal half of inner edge of tarsus absent; inner metatarsal tubercle oval and slightly raised; outer metatarsal tubercle round, slightly raised, about two-thirds length of inner metatarsal tubercle; supernumerary plantar tubercles conspicuous; subarticular tubercles flat, barely conspicuous; digital pads distinct; webbing formula of foot $\mathbf{I}(1 / 2)-(1 / 2) \mathbf{I}(1 / 2)-\left(1 \frac{1}{2}-\right) \mathbf{I I} \mathbf{I}\left(1^{+}\right)-\left(3^{-}\right) \mathbf{I V}(2)-(1) \mathbf{V}$; relative length of toes $\mathrm{I}<\mathrm{II}<\mathrm{III}>\mathrm{V}<\mathrm{IV}$.

Dorsal surfaces of head and shoulders smooth; flanks, dorsum of sacral region, thighs, and proximal surfaces of forelimbs bearing numerous spiculae; spiculae occur singly or in groups of up to six; throat rugose; chest, belly, undersides of limbs nearly smooth, except arm warty and ventral surfaces of thighs rugose; cloacal opening inconspicuous tube at upper level of thighs, directed posteriorly; round warts surrounding rugose cloacal opening.

Color in preservative (70-75\% ethanol): dorsal surfaces of head, body and limbs blackish gray, darker at limbs and margin of head; creamy white area at lower margin of eye; flanks paler than dorsal surfaces; margin of cloacal opening blackish gray; irregular gray mark on pelvic patch. Minute gray stippling on dorsum of body (viewed at 8x magnification); dark gray spots at base of gray spiculae; throat, chest, belly, and ventral surfaces of arms and thighs uniform cream; other ventral surfaces of limbs gray; palmar surfaces gray except for cream palmar, thenar and some subarticular and supernumerary tubercles; inner and outer metatarsal tubercles cream in contrast to adjacent dark gray areas; proximal end of tongue lacking black pigment; lower lip entirely creamy white.

Color in life (from a color transparency of holotype QCAZ 15013 in posterodorsal view): Dorsum of body and limbs dark green, flanks yellowish green; spiculae black.

Holotype measurements (mm): SVL 41.8, TIBL 13.9, FOOT 14.5, HLSQ 11.6, HDWD 10.6, ITNR 3.9, EYDM 3.2, EYNO 2.8, RDUL 11.2, HAND 10.4, THBL 7.3, SW 11.4.

Variation. Meristic variation is given in Table 4. A female paratopotype (QCAZ 15014) resembles the holotype except that it has a slightly darker dorsum; the inner and outer palmar and plantar tubercles show more contrast to adjacent areas, and the outer plantar tubercle is more swollen. Other paratypes from the same general area of the holotype (EPN 3238-3255; QCAZ 1051, 1053, 3742), from Tulcán (MNHG 2258.642258.74, QCAZ 57-58, 1908-1915), from San Gabriel (QCAZ 15018), and from 20-38 km SW of Tulcán (KU 164759-164837, 164841-48, 166296-166300, 202255-67) are similar to that above described with the following noteworthy exceptions. Color of the dorsum in preservative varies from plain greenish gray (EPN 3242) to plain dark brownish gray (EPN 3251) and plain black (KU 164759-164837, 164841-48, 166296166300); a male (EPN 3248) has dark brown marks on a pale gray background, forming a marbled pattern on dorsum of head and body. A narrow middorsal brown line from the tip of the snout to the cloacal region is conspicuous in nine specimens, whereas it is barely visible or absent in others. In all specimens, the flanks are paler than the dorsum and vary from cream in contrast to a dark brown dorsum (EPN 3247) to only slightly paler than a greenish gray dorsum (EPN 3242). A juvenile (QCAZ 1914) possesses few, creamy white spiculae on the lower flanks. The throat, chest and belly are uniform yellowish cream. One female from the type locality (QCAZ 15011) has a patch of white warts with scattered dark pigments on the chest. A brown or gray mark at the pelvic patch region varies from absent to barely conspicuous. The ventral surfaces of limbs mostly vary in the degree of contrast between the palmar and plantar tubercles with the adjacent areas; for example, in EPN 3245 the palmar surfaces are nearly entirely yellowish cream, whereas in EPN 3239 there is a high color contrast between the palmar tubercles and the adjacent areas. In females, there is variation in size, abundance and distribution of spiculae; for example EPN 3244 has abundant and large spiculae, whereas EPN 3242 has few spiculae on the dorsum of body. Juveniles possess spiculae and warts about equally abundant as in adults. 
TABLE 4. Meristic variation of Atelopus pastuso. Mean \pm one SD, and range are given. Abbreviations follow Gray and Cannatella (1985) and Coloma et al. (2000). They are: SVL = snout-vent length; TIBL = tibia length; FOOT = footh length; HLSQ= head length; HDWD = head width; EYDM = eye diameter; EYNO = eye-nostril distance; ITNA = internarial distance; RDUL = radio-ulna length; THBL = thumb length; $\mathrm{SW}=$ sacrum width. All measurements are in mm.

\begin{tabular}{|c|c|c|}
\hline \multicolumn{3}{|c|}{ Atelopus pastuso } \\
\hline & $\begin{array}{c}\text { Males } \\
(n=128)\end{array}$ & $\begin{array}{l}\text { Females } \\
(n=153)\end{array}$ \\
\hline SVL & $\begin{array}{l}31.82 \pm 2.42 \\
(26.1-38.9)\end{array}$ & $\begin{array}{l}38.68 \pm 3.89 \\
(29.6-50.7)\end{array}$ \\
\hline TIBL & $\begin{array}{l}11.75 \pm 1.14 \\
(8.5-14.2)\end{array}$ & $\begin{array}{l}13.04 \pm 1.23 \\
(11.2-16.7)\end{array}$ \\
\hline FOOT & $\begin{array}{l}12,82 \pm 1,30 \\
(9.3-16.0)(n=123)\end{array}$ & $\begin{array}{l}14.8 \pm 1.55 \\
(12.0-20.3)(n=146)\end{array}$ \\
\hline HLSQ & $\begin{array}{l}9.83 \pm 0.69 \\
(7.8-11.5)\end{array}$ & $\begin{array}{l}10.60 \pm 0.85 \\
(9.2-13.5)\end{array}$ \\
\hline HDWD & $\begin{array}{l}9.64 \pm 0.63 \\
(7.5-11)\end{array}$ & $\begin{array}{l}10.48 \pm 0.84 \\
(9.0-13.3)\end{array}$ \\
\hline ITNA & $\begin{array}{l}3.35 \pm 0.32 \\
(2.7-4.3)(n=121)\end{array}$ & $\begin{array}{l}3.72 \pm 1.22 \\
(2.7-13.7)(n=144)\end{array}$ \\
\hline RDUL & $\begin{array}{l}9.38 \pm 0.81 \\
(7.3-11.6)(n=121)\end{array}$ & $\begin{array}{l}10.76 \pm 0.94 \\
(8.9-13.4)(n=144)\end{array}$ \\
\hline THBL & $\begin{array}{l}5.38 \pm 0.69 \\
(4.2-8.8)(n=121)\end{array}$ & $\begin{array}{l}6.64 \pm 0.79 \\
(5.1-9.3)(n=144)\end{array}$ \\
\hline SW & $\begin{array}{l}8.86 \pm 0.83 \\
(6.5-11.3)(n=121)\end{array}$ & $\begin{array}{l}10.89 \pm 1.32 \\
(8.2-14.8)(n=144)\end{array}$ \\
\hline RDUL/SVL & $(0.25-0.36)(n=121)$ & $(0.25-0.32)(n=144)$ \\
\hline TIBL/SVL & $(0.30-0.41)$ & $(0.29-0.40)$ \\
\hline HLSQ/SVL & $(0.25-0.35)$ & $(0.24-0.31)$ \\
\hline HDWD/SVL & $(0.25-0.34)$ & $(0.23-0.31)$ \\
\hline
\end{tabular}

In specimens from a population west of the type locality, from Cordillera Troya (EPN 2195-2211), the dorsum varies from plain dark gray to pale brown; the venter is cream.

South of the type locality, specimens from populations at Provincia de Imbabura (QCAZ 2678 from Monte Olivo, MNHG 2385.12-13, 2385.15-30 2385.32-43 from Pimampiro, and QCAZ 15019-22 from Volcán Cotacachi) are more variable in dorsal color. In addition to having a plain dark gray to plain cream dorsum, some specimens have either a marbled dorsum with diffuse dark and pale marks or a dark brown dorsum with cream marks. All are uniform creamy yellow ventrally, but some specimens from Pimampiro have ventral dark marks. A female (MNHG 2385.29) has a brown band across the throat at a level posterior to the mandible, whereas other specimens (MNHG 2385.19, 20, 24, 28, 30, 39, 40, 44, 48, 1 female, 6 males, 2 juveniles) have diffuse brown marks on the chest-gular region. Farther south, two specimens from Laguna Cuicocha (EPN 3312-13, female and male) are similar to the type specimens, except they have a more rugose ventral skin.

Sexual dimorphism is evident in that females are larger than males (Table 4). Males have vocal slits and keratinized nuptial pads on the dorsal and inner surfaces of the thumb (except at terminal phalanx) and on Finger III, on which they are most numerous on the proximal phalanx. The forelimbs are relatively long and slender in females, but they are short with a stout muscular area in males (Table 4); there are significant differences in RDUL between males and females (RDUL Student's $t$-test, $t=12.6718$, $\mathrm{df}=263, P<0.0001$ ). Males nearly lack spiculae but bear abundant warts homogeneously distributed on the flanks and dorsum. 
Color in life. (Figs. 4C-F). Gómez Castillo (1982) described the color in life of populations from Túquerres, El Espino, Guachucal and Cumbal at about 3000 m, in Departamento Nariño, Colombia, the frogs had a pale green dorsum with black spiculae, and the venters were very pale green to nearly white. Cepeda Quilindo and Rueda Almonacid (2005:135) published color pictures of an amplectant pair and of an individual in dorsal and ventral view (locality not stated). Almendáriz and Cisneros (2005:153) described individuals (including a photo) from Lagunas Verdes, Provincia del Carchi; EPN 3238 has a black dorsum and a lemon green venter with a black anal pelvic patch bordered by orange (AA field notes of 26 January 1988). The following are taken from color photographs and/or descriptions of coloration in life in field notes. Adult male from the type locality, QCAZ 15009 (color slide in anterolateral view, taken by Eugenia del Pino): flanks and dorsal surfaces of limbs green; suborbital region and throat yellow; spiculae on arms black; iris black.

Páramo de El Ángel, 20 km SW Tulcán, 3350 m (KU 164759-848; WED field notes, 18 May 1975, photo of 164759): dorsum black with grayish green flanks in some individuals; venter yellowish green (predominantly yellow on throat and ventral surfaces of hind limbs; predominantly green on belly) or venter uniformly green (throat in some dull creamy white); soles greenish gray; ventral border of orbit pale yellow; iris dark brown.

Two adult females from Tulcán, MHNG 2258.68 (two color slides in dorsal view taken by LAC), MNHG 2258.65 (two color slides in dorsolateral view taken by LAC): In MHNG 2258.68, dorsum nearly uniform greenish cream, except spiculae nearly black; gray suffusion in supraorbital region, forearm, dorsal surfaces of hands and feet; gray bands across fingers and toes; outer palmar tubercle cream; outer plantar tubercle white. MNHG 2258.65 similar to above, except for having four large, diffuse, round, gray marks on dorsum of head and body; flanks greenish-cream with a pale yellowish-cream suborbital area. The iris is black.

QCAZ 3742, female from 42 W of Tulcán (LAC field notes, 2 March 1993): dorsum greenish black with a reticulate pattern; venter yellowish-cream.

QCAZ 1908-15, 1051, 1053, from 26.6 km W of Tulcán, near Volcán Chiles (LAC field notes of 8 June 1989): dorsum greenish black; flanks and venter pale green to yellow; spiculae black; palmar and plantar tubercles creamy yellow; suborbital region yellowish green; iris black. QCAZ 1911 (juvenile, two color slides of venter taken by LAC): throat, chest and belly pale yellow; lower lip with whitish-cream margin; black pelvic mark; limbs gray ventrally, except tips of fingers and toes black; black stripe extends along mid-length of fingers; black marks on plantar surfaces; palmar and plantar tubercles whitish-cream; outer metatarsal tubercle white.

EPN 3239-55, from Hacienda La Esperanza (AA field notes, 12 February 1986): dorsum plain black to pale gray, olive green, or green; venter yellow to sulfur-yellow and green-yellow with a black pelvic mark. EPN 3253 with black cephalic region extending to middorsum and changing to olive-green posteriorly; gular region bright yellow; abdominal region yellow; extremities olive-green; anal mark orange.

QCAZ 15018, female from San Gabriel (color slide in dorsolateral view taken by Eugenia del Pino): dorsum of head, body, and limbs bright green; flanks yellowish green; spiculae black, canthus, eyelid, and postorbital ridge dark gray.

QCAZ 15019-22, two females and two males from Volcán Cotacachi (Eugenia del Pino Lab notes, November 1976): dorsum grayish green; coni black; throat, venter and undersides of forearms yellow; brown or gray mark surrounding anal region. In life, female (QCAZ 15019) from Volcán Cotacachi had a grayish green dorsum with black pointed spiculae; the cloacal region was brown to gray, and the gular region and ventral surfaces of the hind limbs and forearm were yellow, but with a patch of white warts on chest-gular region (Eugenia del Pino, Lab notes, 13 November 1976).

Tadpoles. Unknown.

Distribution, ecology, natural history, and conservation status. Atelopus pastuso is known only from paramo and subparamo habitats from Departamento Nariño in southern Colombia to Provincia Imbabura in northern Ecuador. It occurs in the following natural formations (according to the classification proposed by Valencia et al. 1999): Páramo de Frailejones, Páramo Herbáceo, Bosque Siempre Verde Montano Alto and Bosque de Neblina Montano. These habitats lie between 2800-3900 m in the high massif of the Nudo de Pasto (as defined by Duellman 1979) and in the northern extreme of the Cordillera Occidental del Ecuador 
(Fig. 5). The area of its extent of occurrence is of about $3127 \mathrm{~km}^{2}$. One locality of A. pastuso at the western versant of Cordillera Occidental is in close proximity to the Ecuadorian localities of A. angelito (Fig. 5); thus, they might have occurred in parapatry or sympatry at these localities. At the type locality, Páramo de El Ángel, annual mean rainfall is $1275 \mathrm{~mm}$ and the annual mean temperature is $6.9^{\circ} \mathrm{C}$ (Hijmans et al. 2005). $\mathrm{KU}$ 164759-848 (WED field notes, 18 May 1975) from Páramo de El Ángel, 20 km SW Tulcán, 3350 m above sea level were found at wet paramo, grazed, with bunch grass and few cushion plants. At the time of collection, one individual was under rock by day; others were crawling on ground and amid vegetation (some \pm 20 $\mathrm{cm}$ above ground on sunny side of bunch grass). Temperature data $\left({ }^{\circ} \mathrm{C}\right)$ were taken for KU $164761-164779$ and are shown in Table 5. As reported by Duellman and Trueb (1986:216 as A. ignescens), these black frogs are able to raise their body temperatures rapidly by climbing onto sunny sides of bunch grass; within half an hour after emergence, 20 individuals had body temperatures of 0.5 to $4.6^{\circ} \mathrm{C}$ (mean $=1.45^{\circ} \mathrm{C}$ ) above the adjacent substrate. EPN 3239-55 from Hacienda La Esperanza were found between 8:30 to 10:30 hours under stones and trunks in a cypress forest surrounded by cultivated fields (AA field notes, 12 February 1983).

TABLE 5. Temperature variation $\left({ }^{\circ} \mathrm{C}\right)$ of Atelopus pastuso (KU 164761-14779).

\begin{tabular}{ccc}
\hline Frog Temperature & Substrate Temperature & Air Temperature \\
\hline 14.4 & 13.0 & 10.2 \\
15.0 & 14.2 & 10.2 \\
14.8 & 13.0 & 10.2 \\
18.4 & 17.6 & 10.2 \\
15.6 & 14.6 & 10.2 \\
17.6 & 17.6 & 12.4 \\
19.2 & 17.6 & 12.4 \\
17.6 & 14.8 & 12.4 \\
19.8 & 15.2 & 12.4 \\
17.0 & 14.4 & 12.4 \\
15.6 & 14.5 & 12.4 \\
15.2 & 13.4 & 12.4 \\
13.4 & 12.0 & 12.4 \\
16.2 & 15.0 & 12.4 \\
16.8 & 15.8 & 12.4 \\
22.5 & 20.8 & 12.4 \\
17.0 & 15.5 & 12.4 \\
17.5 & 16.8 & 12.4 \\
17.5 & 17.0 & 13.0 \\
18.2 & 17.5 & 13.0 \\
\hline
\end{tabular}

Adult gravid females were collected on 18 May 1975, 13 November 1976, 12 January 1980, 5 April 1985, 13 March 1986, August 1986, 2 March 1993; the smallest juvenile (MHNG 2385.51, SVL $12.8 \mathrm{~mm}$ ) was collected on August 1986. An amplectant pair (QCAZ 15021, male; 15019, female) was collected on 13 November 1976; the female had white eggs and a reddish-white oviduct; the male had pink fat bodies, large testes with the Bidder's organs (few oocites) over the ventral surfaces of the gonads; in female QCAZ 15022 oocites were mononucleate (Eugenia M. del Pino Lab notes, November 1976). Female QCAZ 15019 contains 201 ovarian eggs about $1.85 \mathrm{~mm}$ of diameter $(1.62-2.14 \mathrm{~mm}, \mathrm{SD}=0.139523, n=15)$. 
The stomach contents of four females (MHNG 2258.66-67 from Tulcán, EPN 3244-45 from Espejo) and one male (MHNG 2258.71 from Tulcán) are shown in Table 6. In a female (MHNG 2258.66), approximately $80 \%$ of stomach contents were unidentifiable digested vegetal and animal material; the largest prey item was a Lampyridae larva with a length of $6.27 \mathrm{~mm}$; a wing of an undetermined Hymenoptera was 5.29 long; the most common items, the Acari, were 0.42-1.02 mm long. In a female (MHNG 2258.67), seeds were also observed; approximately $70 \%$ of stomach contents were unidentifiable digested vegetal and animal material; the largest prey item was an unidentified Coleoptera, with elytron $4 \mathrm{~mm}$ long; the most common items, the Acari, were $0.83-0.97 \mathrm{~mm}$ long. In a male (MHNG 2258.71), approximately $75 \%$ of stomach contents were unidentifiable vegetal and animal digested material; the largest prey item was a Lampyridae larva $4 \mathrm{~mm}$ long; the most common items, the Acari, were $0.73-1.30 \mathrm{~mm}$ long.

TABLE 6. Number of prey items in the stomach contents of Atelopus pastuso from Tulcán and Espejo, Provincia Carchi, Ecuador. An asterisc (*) indicates larva.

\begin{tabular}{|c|c|c|c|c|c|}
\hline Taxa & $\begin{array}{c}\text { Female } \\
\text { MHNG 2258.66 }\end{array}$ & $\begin{array}{c}\text { Female } \\
\text { MHNG 2258.67 }\end{array}$ & $\begin{array}{c}\text { Female } \\
\text { EPN } 3244\end{array}$ & $\begin{array}{c}\text { Female } \\
\text { EPN } 3245\end{array}$ & $\begin{array}{c}\text { Male } \\
\text { MHNG 2258.71 }\end{array}$ \\
\hline Acari & 11 & 25 & - & - & 12 \\
\hline Acari (Oribatei) & - & - & - & 5 & - \\
\hline Aracnida & 2 & - & - & 7 & - \\
\hline Apterigota & $2 *$ & & - & - & - \\
\hline Coleoptera & 1 & 5 & - & - & 1 \\
\hline Coleoptera (Curculionidae) & - & 2 & - & - & - \\
\hline Coleoptera (Lampyridae) & $1^{*}$ & - & - & - & $1 *$ \\
\hline Coleoptera (Scolytidae) & - & - & 4 & - & - \\
\hline Coleoptera (Staphylinidae) & - & - & - & 1 & - \\
\hline Collembola & - & 1 & - & - & - \\
\hline Diptera & 2 & 2 & 24 & $1^{*}$ & - \\
\hline Formicidae & 7 & 11 & - & - & 11 \\
\hline Hemiptera & - & 1 & - & - & 1 \\
\hline Hemiptera (Ligaeidae) & - & - & - & 1 & - \\
\hline Homoptera & & & - & 5 & \\
\hline (Aphidae) & - & - & & & - \\
\hline Homoptera (Delphacidae) & - & - & - & 1 & - \\
\hline Hymenoptera & - & - & 17 & - & - \\
\hline Hymenoptera (Eulophidae) & - & - & - & 7 & - \\
\hline Lepidoptera & - & - & - & $1^{*}$ & - \\
\hline Total & 26 & 47 & 45 & 29 & 26 \\
\hline
\end{tabular}

Atelopus pastuso is considered to be Critically Endangered (Possibly Extinct) (A2ace, IUCN Red List categories and criteria). The species is tagged as Possibly Extinct until further surveys confirm otherwise. The population has declined dramatically (more than $80 \%$ ) in the last two decades probably because of climate change and the impact of pathogens, which have affected many other montane species of Atelopus.

This species was abundant at least at some localities. On 18 May 1975, a field party from the University of Kansas recorded 90 individuals (0.50 ind/pers/min) at Páramo El Angel (Carchi Province; $3350 \mathrm{~m}$; WED field notes). Alméndariz and Orcés (2004) reported, in 1986, densities of 10 individuals per square meter in Páramo de El Ángel. The last living individuals were seen in 1993, in spite of many collecting efforts at sev- 
eral localities throughout the entire range of its distribution. In Colombia, although this species previously was abundant at several localities, no individuals have been found after 16 November 1982, despite intensive search efforts since the mid-1990's (Cepeda-Quilindo and Rueda-Almonacid 2005).

In Ecuador, several dead or unhealthy individuals were found throughout its range before its disappearance: QCAZ 3742 was collected in an unhealthy condition at $42 \mathrm{~km} \mathrm{~W}$ of Tulcán; it was active at 15:35h, close to the road and at about $5 \mathrm{~m}$ from a stream in natural forest; the animal died the next day after capture (LAC field notes, 2 March 1993). The last living individuals were observed (but not collected) on 29 June 1993, when six additional individuals were found dead between 13:00h and 14:00h at Quebrada Chumaví, 9 km N of Cuicocha, Imbabura Province (putative hybrid zone, see under Remarks). Merino-Viteri (2001) examined three of these specimens (QCAZ 3691, 3699, 3742) and reported them as positive for chytrid infection.

Etymology. The specific name pastuso is used as a noun in apposition. Pastuso is a Spanish word, which refers to the inhabitants of the Pasto region in southern Colombia and northern Ecuador.

Remarks. Twenty-one specimens from an area of about $26.4 \mathrm{~km}^{2}$ (Fig. 5)—La Joya-Huagsi (SW of Otavalo) (QCAZ 15016-17), Hacienda Curubí (Páramos de Mojanda) (EPN 3299-301), and Quebrada Chumaví, 9 km N of Cuicocha (QCAZ 3691-92, 3695-700, 4050, 4798-802; EPN 3312-13)—are similar in coloration to either A. pastuso or A. ignescens. However, among them, eight of 15 females that are similar in coloration to A. pastuso, bear a patch of brown pustules and spiculae in chest-throat region. The latter is characteristic of A. ignescens, A. ardila, and A. carrikeri. The presence and absence of this feature in specimens from these localities and the occurrence of individuals that have coloration of either A. ignescens or A. pastuso is intriguing. This polymorphism and mixture of characters suggests the possibility of hybridization at the contact zone between A. ignescens and A. pastuso (see discussion below).

\section{Atelopus podocarpus sp. nov.}

Holotype. QCAZ 6801, adult female, from Lagunas del Compadre ( $4^{\circ} 10^{\prime} \mathrm{S}, 7^{\circ} 06^{\prime} \mathrm{W}$; ca. $\left.3300 \mathrm{~m}\right)$, Parque Nacional Podocarpus, Provincia Loja, Ecuador, collected on 1 December 1994 by Jenny Rudston.

Paratypes. EPN 1223-26, from Lagunas del Compadre (4¹0'20" S, 7906'42" W; 3400 m), Parque Nacional Podocarpus, Provincia Loja, Ecuador, no collection date stated on field notes, but possibly collected on September 1981, by Luis H. Albuja V.; EPN 2143-45, from Cerro Toledo (4²3' S, 7906' W; 2900 m), Provincia Loja, Ecuador, collected on 11 September 1981 by Luis H. Albuja V.; EPN 3235, 3237, Mirador path nearby the Centro Administrativo Cajanuma of the Parque Nacional Podocarpus (358'09" S, 7908'06" W; 2850-2990 m), Provincia Loja, Ecuador, obtained on 16-18 November 1986 by Ana Almendariz; KU 120389, from $15 \mathrm{~km}$ east of Loja (2700 m), Provincia Zamora Chinchipe, Ecuador, obtained on 10 June 1968 by John D. Lynch; KU 165004-5, from $13 \mathrm{~km}$ east of Loja (358' S, 7906' W), Abra de Zamora, Provincia Loja, Ecuador; KU 178418, from Provincia Zamora Chinchipe: $13.7 \mathrm{~km}$ east of Loja ( $3^{\circ} 58^{\prime} \mathrm{S}, 7^{\circ} 06^{\prime} \mathrm{W}$ ), Provincia Loja, Ecuador; KU 201115-7, from 3.7 km south of Saraguro (338'49" S, 79¹4'42" W; $2800 \mathrm{~m}$ ), collected on 08 March 1984 by J. E. Simmons; QCAZ 2838 (cleared and double stained skeleton), from Centro Administrativo Cajanuma (407' S, 79 09' W; 2800 m), Parque Nacional Podocarpus, obtained on 25 June 1987 by Luis A. Coloma, Mario García Saltos, and Renato León.

Referred specimens. KU 196633-40, from west slope Cerro Chinguela on Huancabamba-San Ignacio trail, Departamento Piura, Peru, obtained on 14-15 October 1977 by Gary R. Graves; KU 196641-42, from Cerro Chinguela, 5 Km NE Zapalache, 2900 m, Departamento Piura, Peru, obtained on 13 and 20 July 1980 respectively, by L. J. Barkley.

Diagnosis. (1) A species with mean SVL in adult females $47.7 \mathrm{~mm}(39.5-52.9, \mathrm{SD}=3.1, n=22)$ and in adult males $37.7 \mathrm{~mm}(34.4-40.9, \mathrm{SD}=2.6, n=5)$; (2) hind limbs short, tibia length/SVL $0.322-0.424(n=$ 27); (3) phalangeal formula of hand 2-2-3-3; webbing absent; (4) foot webbing formula $\mathbf{I}(0)-(1) \mathbf{I}\left(1 \frac{1}{2}\right)$ (3)III (1) - $\left(3^{-}\right) \mathbf{I V}\left(2^{2} /{ }_{3}\right)-\left(1^{+}\right) \mathbf{V}$; (5) snout acuminate, protruding beyond lower jaw; (6) tympanic membrane and tympanic annulus absent; (7) dorsal surfaces of body smooth; arms and legs surfaces warty; ventral sur- 
face weakly aerolate; (8) red-orange spiculae (cream in preservative) on flanks and some extending to the dorsum; (9) vertebral neural processes inconspicuous; postorbital and cranial crests present; (10) dorsum entirely black, flanks with or without cream marks; (11) no minute gray stippling on dorsum of body; (12) venter and throat pale green and cream (cream or yellow in preservative), with or without dark marks; (13) gular region lacking warts, spiculae, or coni.

Atelopus podocarpus sp. nov. is most easily confused with A. petersi from the north and east-central flanks of the Ecuadorian Cordillera Oriental of the Andes. The two species have similar color patterns and body proportions. However, A. podocarpus can be easily differentiated by having numerous minute brownred-orange spiculae (in life) on the flanks (18-71 spiculae on the flanks between the arms and legs counted in a straight line); in contrast, $A$. petersi has white spiculae aggregated into few small warts (1-21 spiculae per wart; 8-15 warts on flanks between arms and legs counted in a straight line) (Figs. 10, 11A-B). Atelopus podocarpus differs from A. bomolochos (from the southern Andes of Ecuador) and A. pachydermus O. Schmidt (from south Andean Ecuador and northern Peru) in the dorsal coloration in life; A. podocarpus has a black dorsum, whereas A. pachydermus has a yellow and brown dorsum and A. bomolochos has a yellow to dark green dorsum (Coloma et al. 2007:Fig. 3A-D). Atelopus peruensis Gray and Cannatella (from northern Peru) is slightly smaller than A. podocarpus (SVL in A. peruensis $=32.8-38.5$ in adult males; $38.4-45.2 \mathrm{~mm}$ in adult females; Venegas 2005), has, in life, black flanks with white warts (red flanks in A. podocarpus), and a non-protruding snout (protruding in A. podocarpus). Atelopus podocarpus and A. ignescens (from the northern Andes of Ecuador) are similar in size and coloration (in preservative), but A. ignescens bears a patch of spiculae and coni on the gular and pectoral regions of females (absent in A. podocarpus). Genetically, A. podocarpus is clearly differentiated from A. ignescens, A. bomolochos, A. onorei, and A. peruensis. A molecular phylogenetic analysis shows $A$. halihelos Peters as the sister species of A. podocarpus (Guayasamin et al. 2010). These two species are differentiated by size (male SVL of $A$. podocarpus $=34.4-40.9$ vs 25.3 in holotype of A. halihelos), color pattern (in preservative, black dorsum in A. podocarpus, light brown dorsum in $A$. halihelos), the presence of a discontinuous dorsolateral line of warts in A. halihelos (absent in A. podocarpus), and flanks with some warts with multiple spiculae in A. halihelos (warts never have more than one spiculae in A. podocarpus).

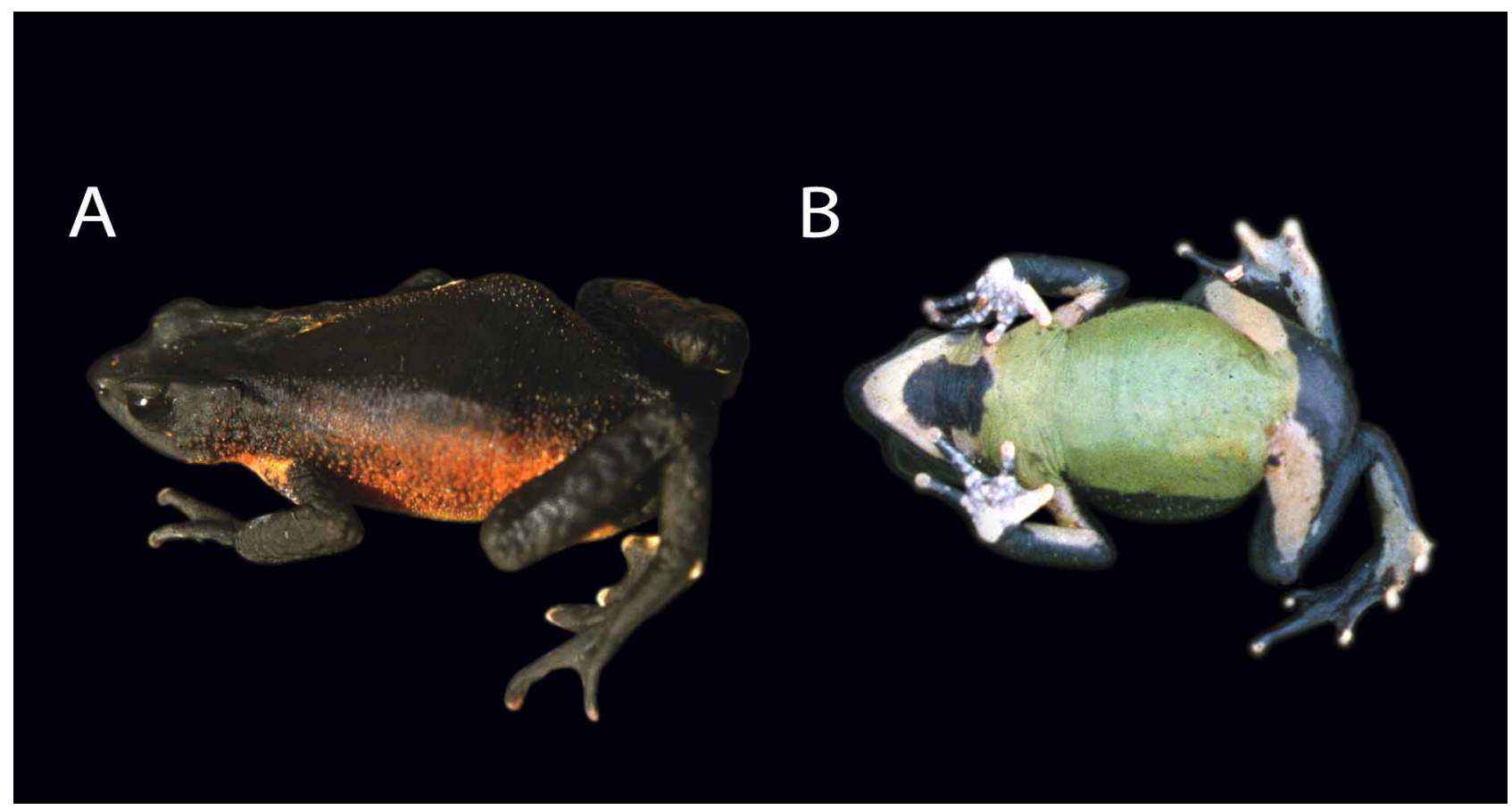

FIGURE 10.-Atelopus podocarpus from Parque Nacional Podocarpus, Provincia Loja, Ecuador: (A) EPN 3235 from Mirador path nearby the Centro Administrativo Cajanuma of the Parque Nacional Podocarpus, 2850 m; (B) EPN 1223 from El Compadre. Photos by AA and Luis H. Albuja V., respectively. 


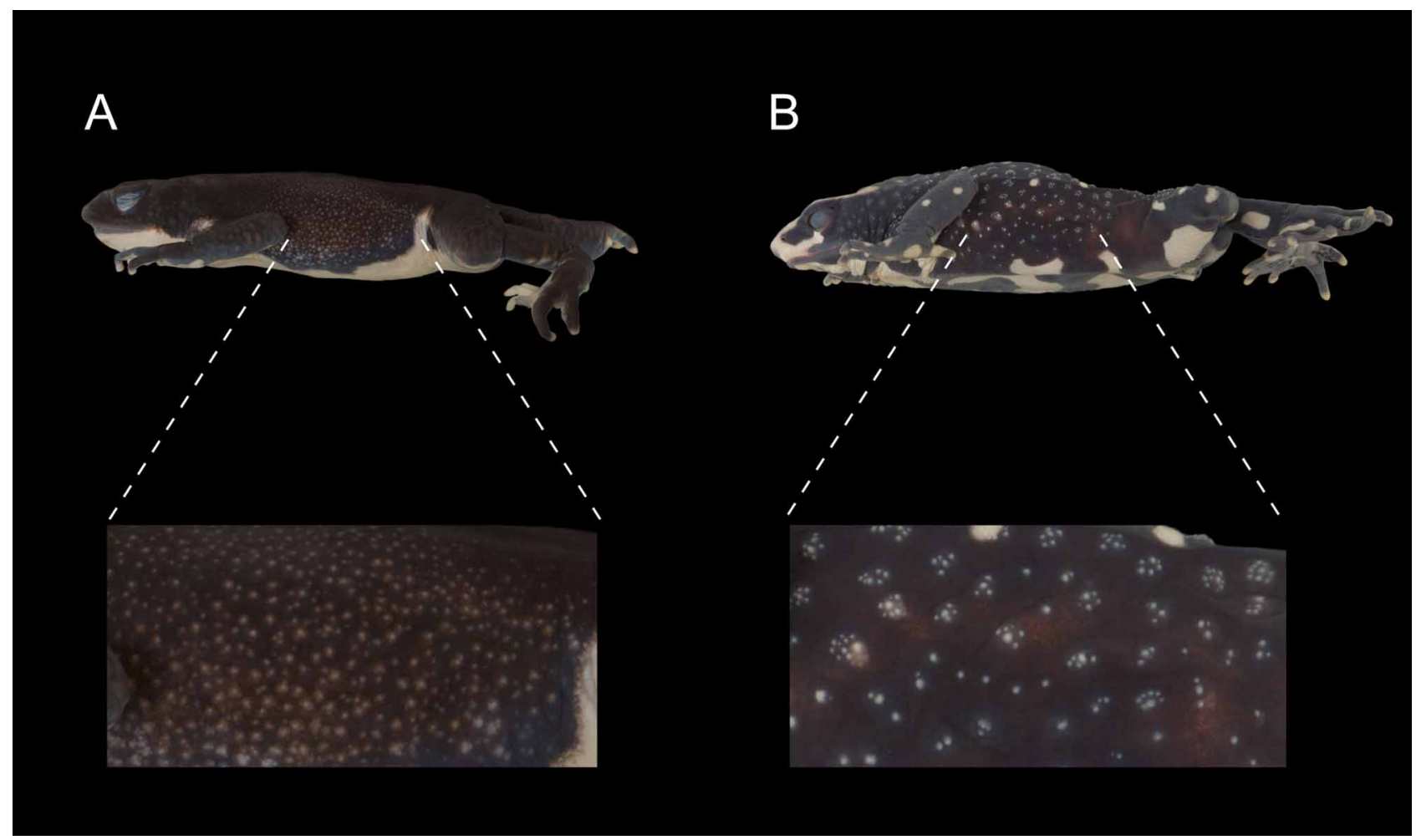

FIGURE 11.-Lateral view of two species of Atelopus, with detail on the distribution of spiculae on flanks. (A) Atelopus podocarpus; (B) A. petersi. Note that multiple spiculae are clustered in A. petersi.

Description of holotype. (Figs. 12A-C, virtual animation). Female. Head about as long as wide; head length and head width less than one third SVL (HLSQ/SVL = 0.276; HDWD/SVL = 0.278); snout acuminate in dorsal view, protruding beyond anterior margin of jaw; nostrils slightly protuberant; canthus rostralis distinct; loreal region concave, lips flared; interorbital region flat and smooth, eyelid without tubercles; postorbital and cranial crests present; tympanic membrane and tympanic annulus absent, tympanic area warty; postorbital and cranial crests.

Forearm relatively short $(\mathrm{RDUL} / \mathrm{SVL}=0.291)$; palmar tubercle round; supernumerary palmar tubercles present; subarticular tubercles not prominent; digital tips with round pads; thumb relatively long (THBL/ HAND $=0.677$ ) having two phalanges; hand webbing absent; fingers lacking lateral fringes; length of fingers $\mathrm{II}<\mathrm{III}<\mathrm{V}<\mathrm{IV}$. Tibia relatively short (tibia/SVL $=0.335$ ); outer metatarsal tubercle conical, inner metatarsal tubercle not distinctive because the plantar surface is cream (same color as the tubercle); supernumerary plantar tubercles absent; subarticular tubercles not prominent; digital pads rounded; webbing formula $\mathbf{I}(0)$ (1)III $\left({ }^{1} / 2\right)-(3) \mathbf{I I I}(1)-\left(3^{-}\right) \quad \mathbf{I V}\left(2^{2} / /_{3}\right)-\left(1^{+}\right) \mathbf{V}$; webbing becoming fringe-like distally; length of toes $\mathrm{I}<\mathrm{II}<\mathrm{III}<\mathrm{V}<\mathrm{IV}$.

Dorsum smooth; numerous cream-brownish spiculae on flanks; low warts on tympanic area; low warts on dorsal surfaces of arms and legs; ventral surface weakly areolate; area surrounding the cloacal opening warty. In preservative ( $70 \%$ ethanol), dorsum and flanks black; no minute gray stippling regularly distributed on dorsum of body; dorsal surfaces of tips of fingers and toes cream, in contrast to adjacent black phalanges; Fingers II and III, and Toes I-III cream; venter and throat cream with irregular dark marks on throat and a discontinuous dark mid-stripe on belly; palms and soles black with cream marks; inner surfaces of arms cream; inner part of thighs and shanks black and cream.

Measurements of holotype (mm): SVL 50.8, TIBL 17.0, FOOT 19.5, HLSQ 14.0, HDWD 14.1, ITNR 4.5, EYDM 4.5, RDUL 14.8, HAND 12.4, THBL 8.4, SW 11.0

Variation. Meristic variation is given in Table 7. Low warts on the arms and legs are evident is some specimens (EPN 1225, 2143, 3235, 3237, KU 201115, 201117) and absent in others (EPN 1223, 1224, 2144, KU 201116); some individuals lack warts in the tympanic area (EPN 1223, 3237); three specimens have spiculae on the tympanic area (EPN 3235, KU 201116-17). 


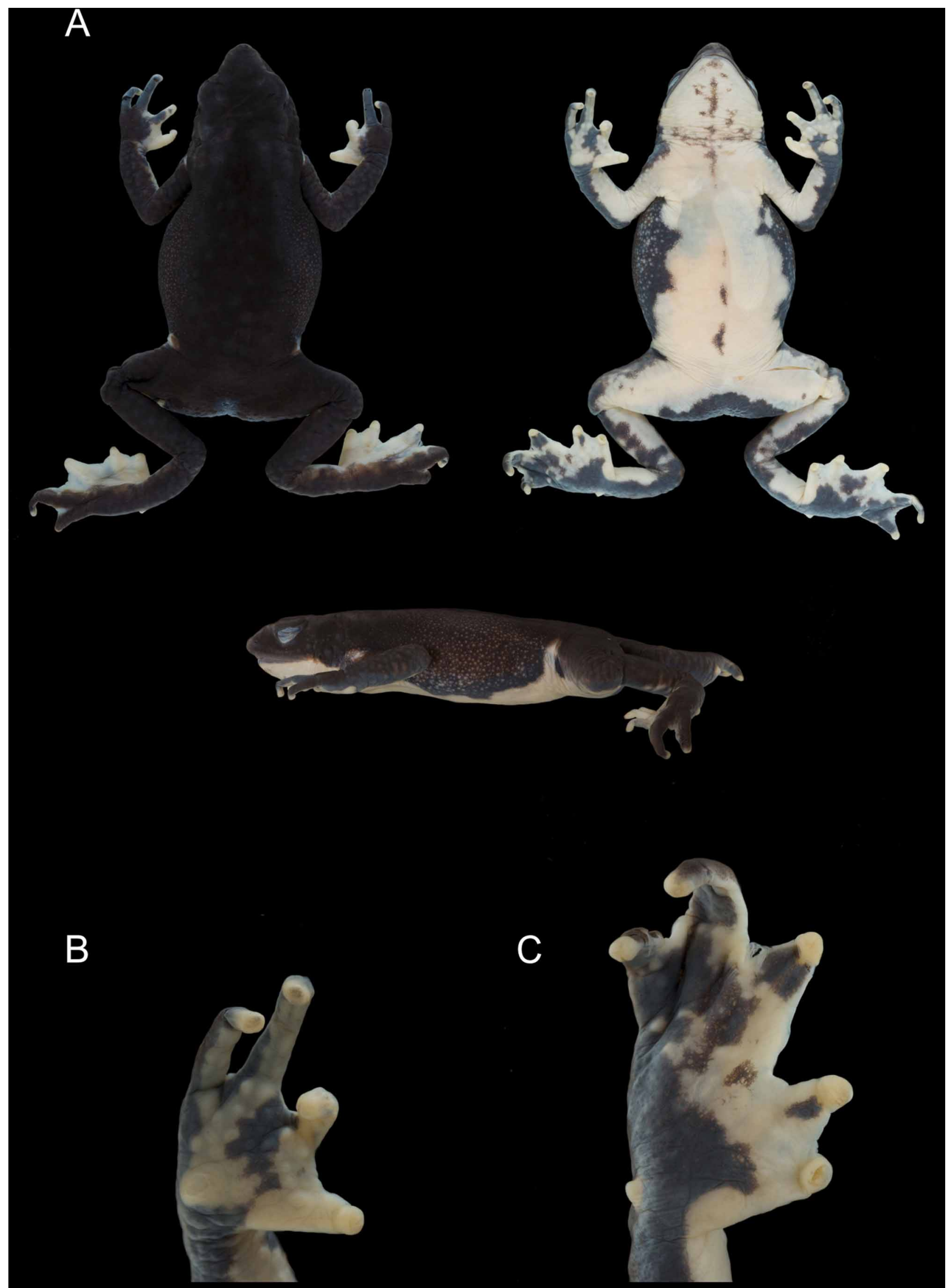

FIGURE 12.-Holotype of Atelopus podocarpus (QCAZ 6801): (A) adult female, SVL $=50.8 \mathrm{~mm}$; (B) ventral view of right hand, enlarged 3.3 times of $\mathrm{A}$; (C) ventral view of right foot; enlarged 3.3 times of $\mathrm{A}$. 
TABLE 7. Measurements (in mm) of the type series of Atelopus podocarpus. Mean \pm standard deviation (range). Abbreviations follow Gray and Cannatella (1985) and Coloma et al. (2000). They are: SVL = snout-vent length; TIBL = tibia length; FOOT = footh length; HLSQ= head length; HDWD = head width; EYDM = eye diameter; EYNO = eye-nostril distance; ITNA = internarial distance; RDUL = radio-ulna length; THBL = thumb length; SW = sacrum width. All measurements are in $\mathrm{mm}$.

\begin{tabular}{|c|c|c|}
\hline & Females $(n=21)$ & Males $(n=5)$ \\
\hline SVL & $46.6 \pm 3.13(39.5-52.9)$ & $37.7 \pm 2.6(34.4-40.9)$ \\
\hline TIBL & $16.8 \pm 1.31(15.0-19.5)$ & $15.0 \pm 0.9(13.5-15.9)$ \\
\hline FOOT & $18.2 \pm 1.48(15.7-21.8)$ & $15.4 \pm 1.7(13.0-17.1, n=4)$ \\
\hline HLSQ & $13.3 \pm 1.11(11.0-14.8)$ & $12.0 \pm 0.7(11.0-12.8)$ \\
\hline HDWD & $12.4 \pm 1.04(10.7-14.1)$ & $11.1 \pm 0.6(10.2-11.6)$ \\
\hline EYDM & $4.2 \pm 0.38(3.5-4.9)$ & $4.2 \pm 0.3(3.8-4.5)$ \\
\hline ITNA & $4.6 \pm 0.58(3.6-5.8)$ & $4.1 \pm 0.2(3.9-4.4)$ \\
\hline RDUL & $13.7 \pm 0.83(12.4-15.2)$ & $11.7 \pm 0.6(10.9-12.3)$ \\
\hline HAND & $11.6 \pm 0.88(9.7-13.6)$ & $10.1 \pm 0.6(9.6-10.8, n=4)$ \\
\hline THBL & $7.3 \pm 0.68(6.0-8.6)$ & $6.1 \pm 0.2(6.0-6.2, n=2)$ \\
\hline SW & $13.5 \pm 1.39(10.4-15.4)$ & $12.3 \pm 1.8(10.4-15.3)$ \\
\hline TIBL/SVL & $(0.322-0.413)$ & $(0.366-0.424, n=2)$ \\
\hline HLSQ/SVL & $(0.258-0.318)$ & $(0.310-0.326)$ \\
\hline HDWD/SVL & $(0.237-0.29)$ & $(0.273-0.310)$ \\
\hline RDUL/SVL & $(0.269-0.319)$ & $(0.290-0.340)$ \\
\hline THBL/HAND & $(0.535-0.677)$ & $(0.622-0.645)$ \\
\hline
\end{tabular}

Ventral coloration varies among individuals (Fig. 13A-D); some have a black thick longitudinal band on the middle of the throat (EPN 1223, 1225); one individual has black throat and venter with cream marks (EPN 2143); one individual has black throat with two cream marks at the sides at the level of the articulation of the jaw (EPN 2144); generally the inner part of thighs are cream, but they may be black (EPN 2143); the inner part of shanks can be black (EPN 1223-25, 2143-44), cream (EPN 3237) or black with cream marks (EPN 3235 , KU 201115-7). The venter varies from cream to yellowish (KU 201115-7). Fingers and toes are mostly black (except for the tips), but Finger II (EPN 1223-25, 2143-44, 3235, 3237) and Toe I (EPN 1225, 2144, 3237) and Toe II (EPN 1223-24) are entirely cream in some individuals. The inner surface of the arms is black (EPN 2143), cream (EPN 1223-24, 3235, 3237, KU 201115, 201117) or black with cream marks (EPN 1225, 2144, KU 201116). The dorsum and flanks may be the same color, but the flanks may have some cream marks (EPN 2144).

KU 196633-42: Dorsum and flanks uniform black; throat, chest, belly, and ventral surfaces of limbs dull cream. Palmar surfaces dull cream to pale brown, but black with cream palmar tubercles in KU 196633, 19636, and 196641-42. Tips of fingers cream and inner and outer metatarsal tubercles cream in most specimens.

Color in life. (Fig. 10A-B). The following is based on color slides taken by AA (EPN 3235, dorsolateral view) and Luis H. Albuja (EPN 1223, ventral view) at Parque Nacional Podocarpus: Dorsum and dorsal sur- 
faces of arms and legs black; flanks and spiculae in flanks orange red; face black; belly light green, throat cream with black mark in the center; palms and inner surface of arms cream; inner surface of thighs cream.

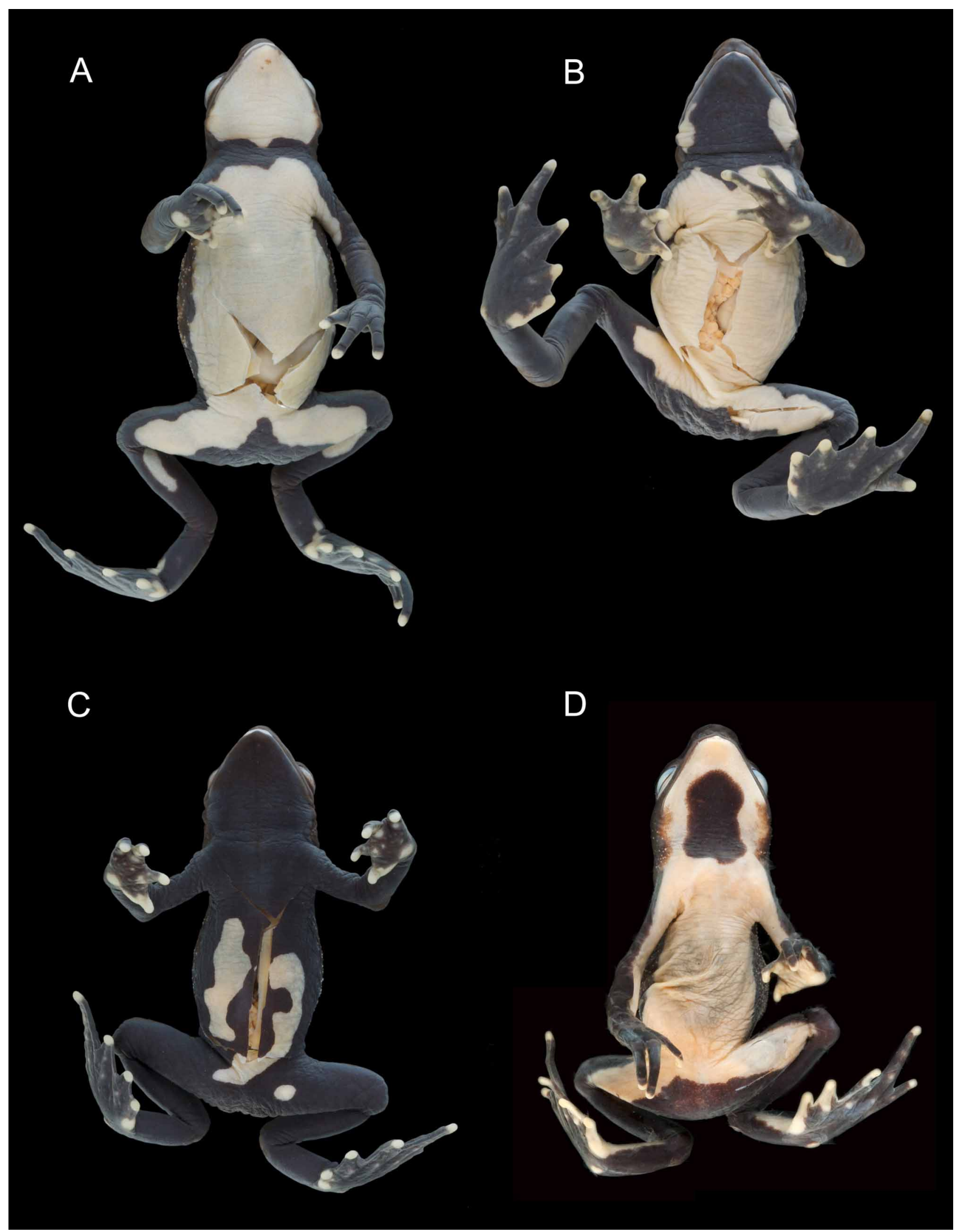

FIGURE 13.-Ventral color variation in Atelopus podocarpus in preservative: (A) EPN 2145; (B) EPN 2144; (C) EPN 2143; (D) EPN 1223. 
KU 165004 (field color notes and slide in dorsolateral view taken by WED on 7 March 1975) from Abra de Zamora, $13 \mathrm{~km}$ E Loja, $2850 \mathrm{~m}$ : Dorsum dull brownish black with dull red tubercles laterally on body. Venter green with tan streak on throat and black stripe on throat and chest. Palmar and tarsal tubercles and tips of digits white. Iris dark brown with bronze wing around pupil.

Distribution, ecology and current population status. Atelopus podocarpus is only known from paramo and subparamo habitats in the southern Cordillera Oriental of Ecuador (Provincias Loja and Zamora Chinchipe) to Departamento Piura in Cordillera de Huancabamba in northern Peru (Fig. 5). In Ecuador, it occurs in the following Natural Formations (classification proposed by Valencia et al. 1999): Herbazal Lacustre Montano, Páramo Arbustivo, Bosque Siempre Verde Montano Alto, and Bosque de Neblina Montano. These habitats lie between 2700-3400 m (Fig. 5). Annual mean rainfall is 1000-2000 mm and annual mean temperature is $7-18^{\circ} \mathrm{C}$ (Cañadas-Cruz, 1983). The area of its extent of occurrence is of about $2475 \mathrm{~km}^{2}$. Habitat and other features of the Podocarpus National Park were described by Rivera-Rosi (2007).

KU 120388-89 (John D. Lynch field notes, 10 June 1968) from Abra de Zamora, 15 Km E Loja, 2800 m were found under stones on dirt banks. KU 165004 (WED field notes, 7 March 1975) from Abra de Zamora, $13 \mathrm{~km}$ E Loja, $2850 \mathrm{~m}$ was found under a rock by day, in elfin, wind-swept scrub with a thick layer of moss, many lichens and liverworts, bromeliads on ground and on bushes, and bamboo. During the day of collection, the temperature was $8.5-18.0^{\circ} \mathrm{C}$ and rainfall was $6 \mathrm{~mm}$.

Atelopus podocarpus is considered to be Critically Endangered (Possibly Extinct) (A2ace, IUCN Red List categories and criteria). The species is tagged as Possibly Extinct until further surveys confirm otherwise. The population has declined dramatically (more than $80 \%$ ) in the last two decades probably because of climate change and the impact of pathogens, which have affected many other montane species of Atelopus. The amphibian chytrid fungus has not been reported yet from Loja or Zamora Chinchipe provinces. The closest record of the chytrid is Azuay Province (Ron and Merino 2000). The risk factor of potential threat caused by the chytrid for anuran amphibian species calculated by Rödder et al. (2009:Fig. 2C) is high at the area of its distribution.

In Ecuador, the last living individual (QCAZ 6801) was seen on 1 December 1994. It was collected in an unhealthy condition at Lagunas del Compadre in Parque Nacional Podocarpus; the animal died while being transported. Collecting efforts at several localities of its distribution (Abra de Zamora in September 2001, August 2003, December 2009; nearby Saraguro in June 2008, Lagunas del Compadre in November 2009) revealed no individuals. In Peru, no individuals have been found since 20 July 1980.

Etymology. The specific name is a noun in apposition and refers to the Podocarpus National Park, where this species formerly lived. Podocarpus takes its name from having the country's largest contingent of the Podocarpus or romerillo tree, the only conifer native to Ecuador. Ecuador's southernmost national park ranges from 1000 meters in the river valleys to 3600 meters in the higher reaches of the Nudo de Sabanilla mountain range, part of the larger Cordillera Oriental. This park of 360,000 hectares shelters an array of cloud forests, subparamo, paramo, a series of small lakes, and many endemic species of flora and fauna.

\section{Atelopus angelito: New country record for Ecuador}

Atelopus angelito Ardila-Robayo and Ruiz-Carranza was named and described from the subparamo of the Páramo de las Papas at Cordillera Central of the Andes in Departamento del Cauca, Colombia, at Municipio de San Sebastián, near Valencia, ca. $1^{\circ} 51^{\prime}$ N, 76 47' W, 2900-3000 m. Their description was based on five adult males, one female and three juveniles. Additionally, Ardila-Robayo (2005) provided data on conservation. Two other females were recorded (under the name Atelopus sp. 14) from Río La Plata, Comunidad de Morán, Reserva Ecológica El Ángel, Provincia Carchi, Ecuador, by Yánez-Muñoz and Altamirano B. (2005). Herein, these specimens are also referred to Atelopus angelito. They provided SVL's for two females, a description of color in life, two photographs (top one, KU 178417), and conservation data. Herein we report additional data of the latter individual KU 178417 (Figs. 4H, 14), an adult gravid female that we consider to be conspecific with $A$. angelito. It was found under a stone $14 \mathrm{~km}$ (airline) SE Maldonado (ca. $0^{\circ} 49^{\prime} \mathrm{N}, 78^{\circ} 3^{\prime}$ 
W, 2500 m), Provincia Carchi, Ecuador, by John D. Lynch, on 31 May 1977. The Ecuadorian localities extend the geographic range of $A$. angelito $183 \mathrm{~km}$ (airline) southwest of its type locality. The color in life of KU 178417 was described by Lynch (field notes, 31 May 1977) as follows: pea green above with black markings; flanks yellow with black, venter orange with black; iris dark brown with yellow edging on pupil. Its measurements and ratios (in mm) are: SVL 49.2, TIBL 17.1, FOOT 19.4, HLSQ 14.1, HDWD 14.3, ITNR 4.6, EYDM 4.5, EYNO 3.5, RDUL 14.0, HAND 11.2, THBL 8.4, SW 16.5, HDWD/SVL $29.1 \%$, HLSQ/SVL $28.7 \%$, HLSQ/HDWD 98.6 \%, EYNO/EYDM $77.7 \%$, TIBL/SVL $34.8 \%$, FOOT/SVL $39.4 \%$.

A comparison of the female (KU 178417) with specimens of the original description of Atelopus angelito does not reveal any major differences, but there are subtle differences in size, amount of foot webbing, and coloration. The only adult female available from the type locality is smaller ( $\mathrm{SVL}=41.0 \mathrm{~mm}$ ) than the Ecuadorian female ( $\mathrm{SVL}=49.2 \mathrm{~mm}$ ). Nonetheless, the two additional adult females (deposited at Museo Ecuatoriano de Ciencias Naturales, MECN) recorded from Ecuador by Yanez-Muñoz and Altamirano B. (2005) have SVLs of 41.3 and $43.8 \mathrm{~mm}$. Thus, adult female size of the topotypic female is very close to the range of variation of Ecuadorian females. The extent of webbing described in the diagnosis and depicted (of a male) in Fig. 3 by Ardila-Robayo and Ruiz-Carranza (1998) is greater than that in the Ecuadorian female. However, the amount of webbing in several specimens (including a female) from the type locality depicted in Fig. 4 by Ardila-Robayo and Ruiz-Carranza (1998) is similar to that in the Ecuadorian female. In the types the flanks are black and creamy white, whereas the flanks in Ecuadorian females are black and yellow. These color differences can be attributed to either intraspecific or geographic inter-population variation; however, sample sizes are too small to know with certainty.

Distribution, ecology, and conservation status. Atelopus angelito is known only from paramo and subparamo habitats at elevations of 2500-3000 m on the eastern slopes of Cordillera Central in Departamento del Cauca in southern Colombia to the western slopes of Cordillera Occidental in Provincia Carchi in northern Ecuador. The area of its extent of occurrence is of about $533 \mathrm{~km}^{2}$. In Ecuador, it occurs in the Bosque de Neblina Montano Natural Formation (according to the classification proposed by Valencia et al. 1999). These localities lie in the high massif of the Nudo de Pasto, as defined by Duellman (1979). At the Ecuadorian locality (14 km SE Maldonado) annual mean rainfall is $1051 \mathrm{~mm}$ and the annual mean temperature is $14.2{ }^{\circ} \mathrm{C}$ (Hijmans et al. 2005). The Ecuadorian localities of Atelopus angelito are in close proximity to one locality of $A$. pastuso at the western versant of Cordillera Occidental (Fig. 5); thus, they might have occurred in parapatry or sympatry at these localities.

Atelopus angelito is considered to be Critically Endangered (Possibly Extinct) (A2ace, IUCN Red List categories and criteria). The species is tagged as Possibly Extinct until further surveys confirm otherwise. The population has declined dramatically (more than $80 \%$; see below) in the last two decades probably because of climate change and the impact of pathogens, that have affected many other montane species of Atelopus.

The last individual of this species was collected 12 April 1995 in Colombia (Ardila-Robayo 2005) and there have been no additional efforts to find it. In Ecuador, the last two living individuals were collected on 22 July 1988, and no additional records exist since that date, in spite of seven occasional searching efforts by QCAZ parties (10 June 1989, 2-3 March 1993, 10 May 1996, 23 October 1999, 17 September 2008, 24 September 2008, 28 September 2009) and intensive searching efforts in 2003 and 2004 by MECN parties at seven nearby sites in Provincia Carchi (Yánez-Muñoz and Altamirano 2005). Presence of the amphibian chytrid fungus was reported in an Ecuadorian locality near the localities for Atelopus angelito and for A. pastuso from 42 km W of Tulcán, Provincia Carchi, in 1993 (Merino-Viteri 2001). 

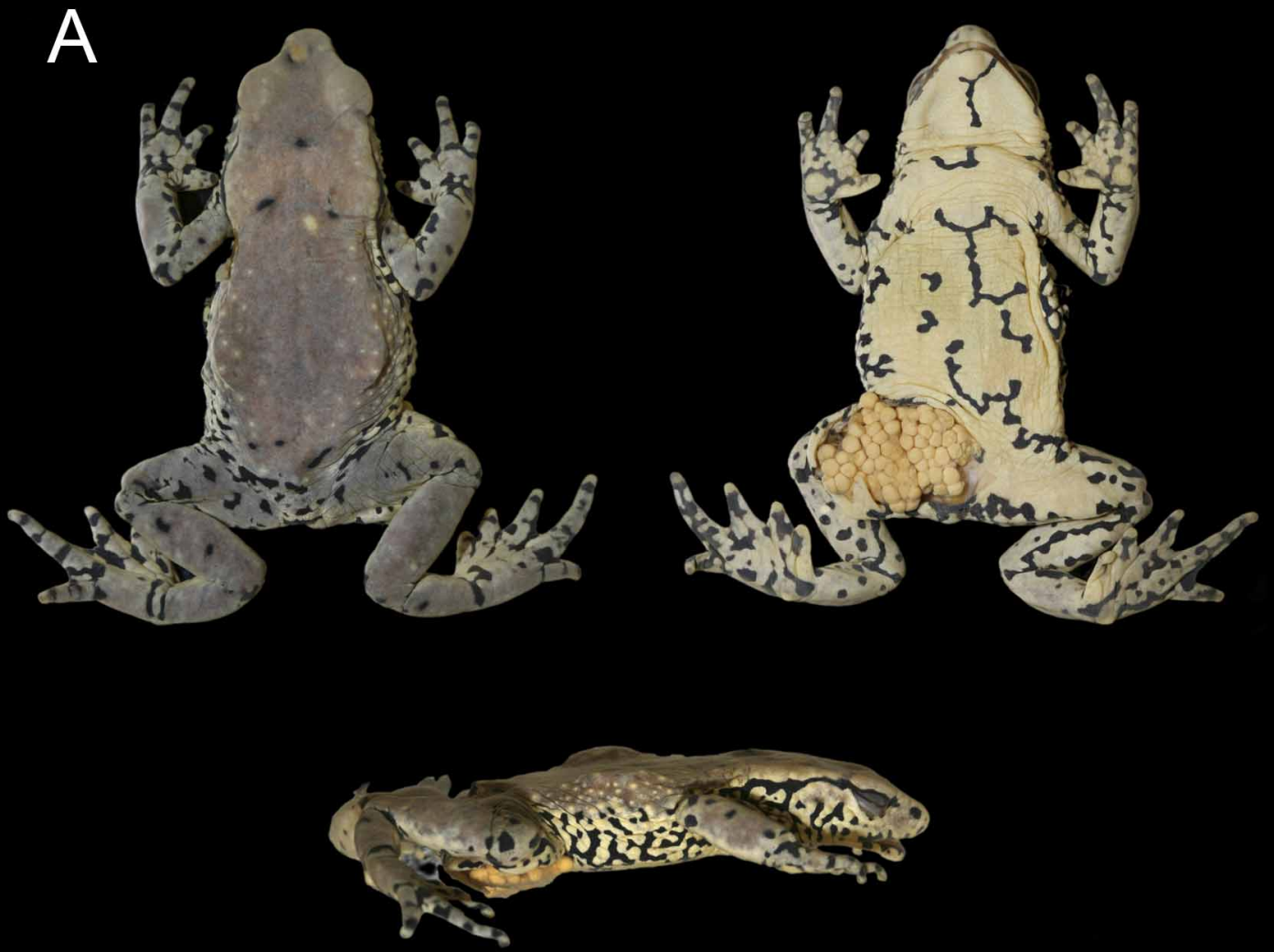

\section{B}

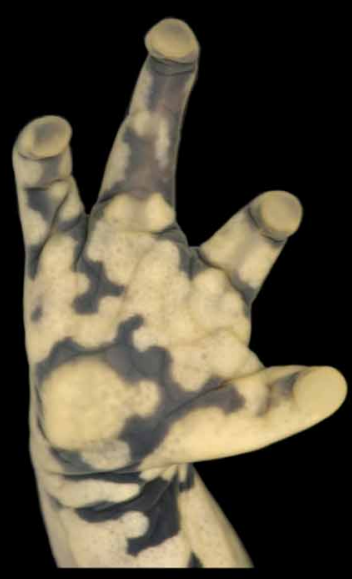

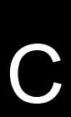

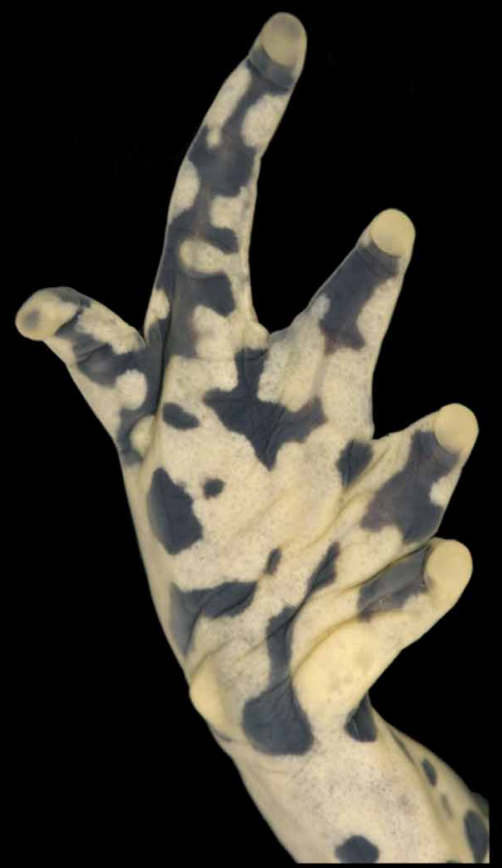

FIGURE 14.-Atelopus angelito (KU 178417): (A) adult female, SVL = $49.2 \mathrm{~mm}$; (B) ventral view of right hand, enlarged 3.5 times of $\mathrm{A}$; $(\mathrm{C})$ ventral view of left foot; enlarged 3.6 times of $\mathrm{A}$. 


\section{Osteology of new species}

The following description applies to all adults of Atelopus ardila, A. gigas, A. pastuso, A. orcesi and A. podocarpus, unless otherwise indicated: one female (KU 169292, SVL $=43.7 \mathrm{~mm}$, double C\&S (cleared and stained), from $12 \mathrm{~km}$ E Pasto, Departamento Nariño), four males (KU 169284, SVL = $38.3 \mathrm{~mm}$, double C\&S; KU 170107, SVL = $41.9 \mathrm{~mm}$, alizarin C\&S; KU 170108, SVL = $41.3 \mathrm{~mm}$, alizarin C\&S; KU 200213, SVL = 38.4 mm, double C\&S; from $12 \mathrm{~km}$ E Pasto, Departamento Nariño) of A. ardila; one female (KU 140318, SVL = $54.5 \mathrm{~mm}$, double C\&S; from La Victoria, Departamento Nariño) of A. gigas; three females (KU 166296, SVL $=39.5 \mathrm{~mm} ; 166297, \mathrm{SVL}=37.3 \mathrm{~mm} ; 166298, \mathrm{SVL}=37.3 \mathrm{~mm}$; all alizarin C\&S, from $20 \mathrm{~km}$ SW Tulcán, Provincia Carchi), and two males (KU 166299, SVL $=32.3 \mathrm{~mm}$; KU 166300, SVL $=33.7 \mathrm{~mm}$; both alizarin C\&S; from $20 \mathrm{~km}$ SW Tulcán, Provincia Carchi) of A. pastuso; one female (MHNG 2684.75, SVL = 42.1, xray image) and one male (MHNG 2559.67, $\mathrm{SVL}=29.4$, $\mathrm{x}$-ray image) of $A$. orcesi; and one female of $A$. podocarpus (QCAZ 2838, SVL $=431 \mathrm{~mm}$, double C\&S). General osteological features of A. ardila (KU 169292), A. gigas (KU 140318), A. pastuso (KU 166298), A. orcesi (MHNG 2684.75, MHNG 2559.67) and A. podocarpus (QCAZ 2838) are depicted in Figures 15-23.

Skull. (Figs. 15, 17, 19, 20, 22). In dorsal view, the skull is triangular, widest posterior to the orbit at the level of the articulation of the maxilla with the quadratojugal, where the skull is as wide as long. A cartilaginous medial septum nasi, paired tectum nasi, and paired oblique cartilages are visible dorsally as a continuous, thin strip at the anterior end of the sphenethmoid and at the anterolateral border of the nasals. The solum and septum nasi are synchondrotically (or synostotically) fused to the large sphenethmoid. No cartilaginous septum nasi is visible. The septum nasi contributes to the medial, anterodorsal configuration of the snout that is protruding relative to the anterior margin of maxilla. Between the tectum nasi and the premaxilla are the alary and prenasal cartilages.
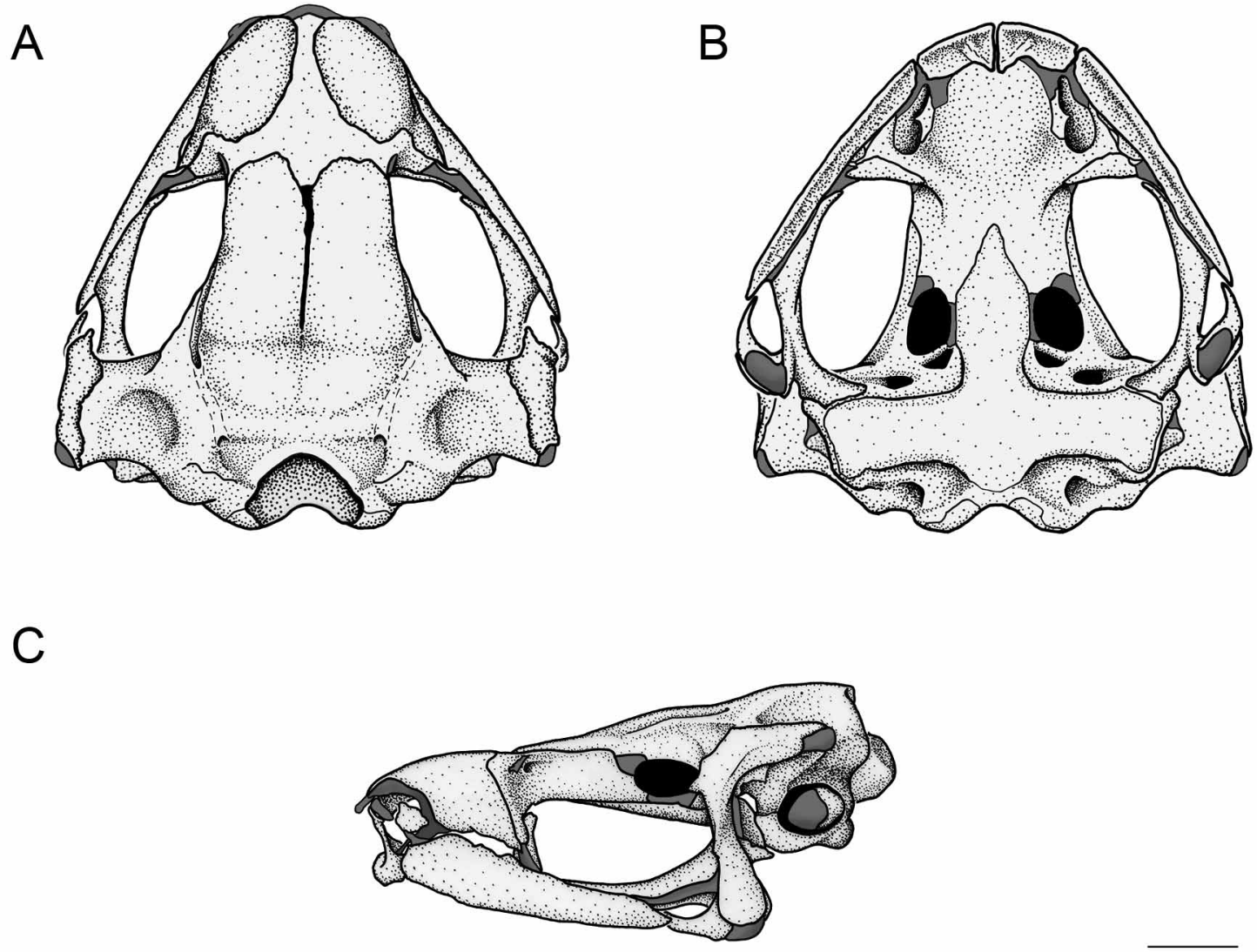

FIGURE 15.-Skull of adult female Atelopus ardila from 7.5 Km E Pasto, Departamento Nariño (KU 200213, SVL = $38.4 \mathrm{~mm}$ ). (A) dorsal, (B) ventral, and (C) lateral views. Scale $=2 \mathrm{~cm}$. Drawings by Diego A. Paucar. 
A

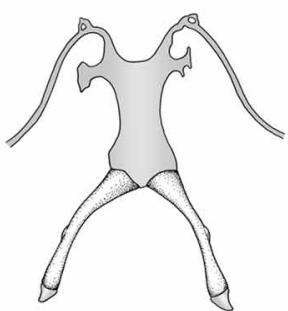

C
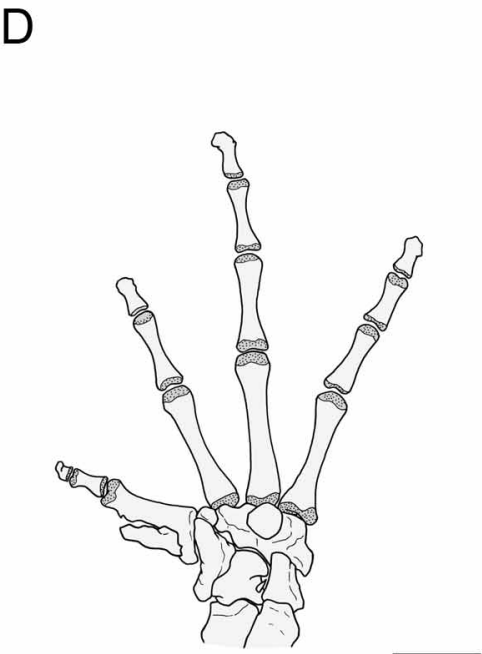

B

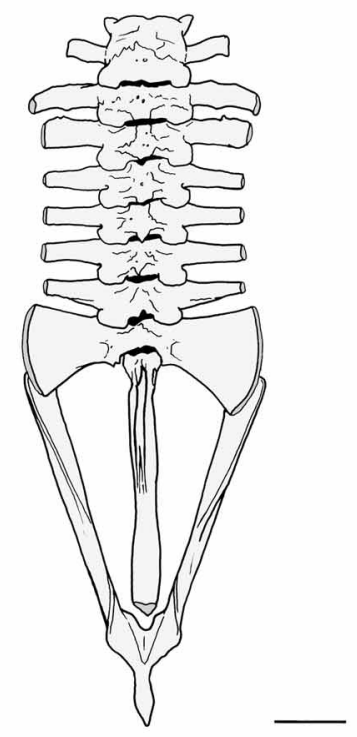

$E$

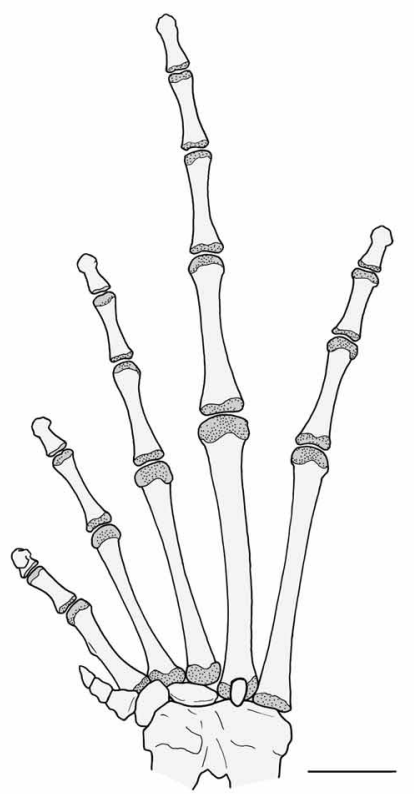

FIGURE 16.-Skeletal features of adult female Atelopus ardila from $7.5 \mathrm{Km}$ E Pasto, Departamento Nariño (KU 200213, SVL = $38.4 \mathrm{~mm}$ ). (A) ventral view of hyobranchium, (B) dorsal view of vertebral column and pelvic girdle, (C) ventral view of pectoral girdle, (D) ventral view of manus, and (E), ventral view of pes. Cartilage is shown in gray. Scale of $\mathrm{A}-\mathrm{C}=3 \mathrm{~mm}$, scale of D-E $=2 \mathrm{~mm}$. Drawings by Diego A. Paucar.

The septomaxilla is a $\cap$-shaped bone with medial and lateral rami; the anterior end is closed. The lateral ramus is broad and bears a nasal process that is elongate, cylindrical and well-differentiated in Atelopus gigas and A. ardila. In A. pastuso, it varies from a pyramidal well-differentiated process (KU 166299) to a cylindrical well-differentiated process (KU 166297). In A. orcesi it is not visible, and in A. podocarpus it is obscured by the staining of the anterior nasal capsule cartilages.

All surfaces of the single sphenethmoid are sculptured, giving it a rough appearance, except its posterior quarter, which is cartilaginous and borders the anterolateral margins of the optic foramina in Atelopus gigas, A. podocarpus, and one specimen of $A$. ardila (KU 169292). In two specimens of A. ardila (KU 200213, 169284), the cartilage is more reduced and mostly confined to the anterolateral corner of the optic foramina. The anterior margin of the bony sphenethmoid almost reaches the anterior margin of the skull. The posterior limits of ossification of the sphenethmoid are at about one-third the length of the margin of the orbit in $A$. gigas, and at varying levels from one-third (KU 169284, 169292) to posterior to midway of orbital region in A. ardila (KU 200213) and A. podocarpus. 

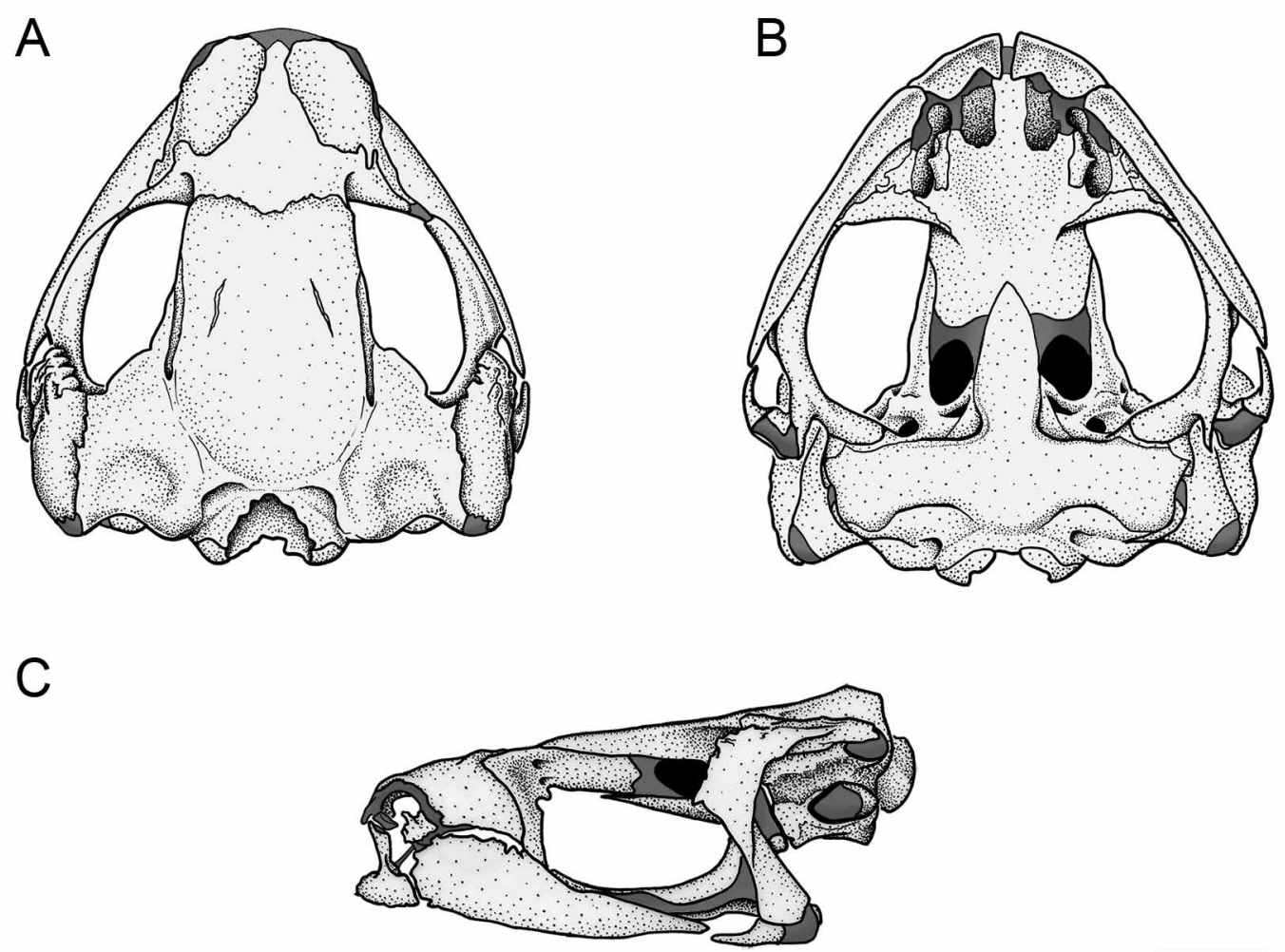

FIGURE 17.-Skull of adult female Atelopus gigas from La Victoria, Departamento Nariño (KU 140318, SVL $=54.5$ $\mathrm{mm}$ ). (A) dorsal, (B) ventral, and (C) lateral views. Scale $=2 \mathrm{~mm}$. Drawings by Diego A. Paucar.

Paired prootics are synostotically united ventromedially; dorsally, they are fused to the posterolateral margins of frontoparietals. The surfaces of the prootic are slightly rugose. The lateral portion (crista parotica) lacks a posterodorsal projection beyond the end of the posterior margin of the cranium. The anterior margin of prootic forms the posterior edge of the optic foramen. The oculomotor and prootic foramina are located at the anteroventral portion of the prootic. The posteroventral margin of the prootic surrounds the ventral margins of the postotic foramen.

Both paired exoccipitals are synostotically united dorso- and ventromedially completely encircling the foramen magnum in bone. The posterior margins of exoccipitals form the posteromedial wall of the otic capsule, the occipital condyle, and the margin of the foramen magnum. A postotic foramen is located just lateral to the occipital condyle. The anteroventral margins of exoccipitals are in contact with the medial posteroventral margin of the parasphenoid.

The otic capsule is well ossified in the region of the inner ear, and bears a cartilaginous crista parotica at its posterolateral margin. Ventrally, the lateral wall of the otic capsule is ossified. A tympanic membrane, tympanic annulus, and stapes are absent. A well-developed cartilaginous operculum lies in the fenestra ovalis. The operculum is conical and oval in lateral view. The operculum is entirely or partially mineralized in all specimens, except in one Atelopus ardila (KU 169292), and one A. pastuso (KU 166297).

The ossified nasals are broadly triangular and separated at midline; each possesses an elongate maxillary process that extends ventrolaterally toward the maxilla. The maxillary process is pointed; the process nearly joins the pars fascialis of maxilla in Atelopus gigas and A. podocarpus; in A. ardila, it varies from reaching the planum orbitale, not reaching the maxilla (KU 169284), to joining the maxilla (KU 169292); in A. pastuso, it nearly joins the maxilla in all specimens, except in KU 166299, in which it joins the maxilla.

The frontoparietals are paired, rectangular bones that roof the dorsal and dorsolateral surfaces of the braincase, from the level just posterior of the anterior margin of the orbit in Atelopus gigas and A. pastuso (more posterior in A. ardila), to close to the margin of the foramen magnum. The frontoparietals cover most of the frontoparietal fontanelle. The frontoparietals articulate medially in A. gigas; in A. ardila the bones do not 
articulate in KU 169284, 169292, 170107 but are articulated of the posterior third in KU 200213 and 170108; there is no medial articulation in A. podocarpus and in A. pastuso, except KU 166300 (A. pastuso) in which they articulate on the posterior third. The frontoparietal fontanelle is narrowly exposed medially when there is no medial articulation. At the level of posterior half of orbit, a lateral frontoparietal flange extends about half the length the anterior margin of the prootic in A. gigas, whereas in A. ardila and A. pastuso, the flange projects only about one-fourth of the length of the anterior margin of the prootic. Occipital grooves are present; the posterior half of each groove in A. gigas is roofed; in A. ardila and A. pastuso, the grooves are completely roofed, except in one specimen of $A$. ardila (KU 200213), in which the groove on the left is roofed slightly behind the level of roofing on the right side. Posteriorly the frontoparietals are synostotically fused (borders of the frontoparietal are difficult to discern) posterolaterally to the prootics, and posteromedially to the medial anterodorsal margins of the exoccipitals.

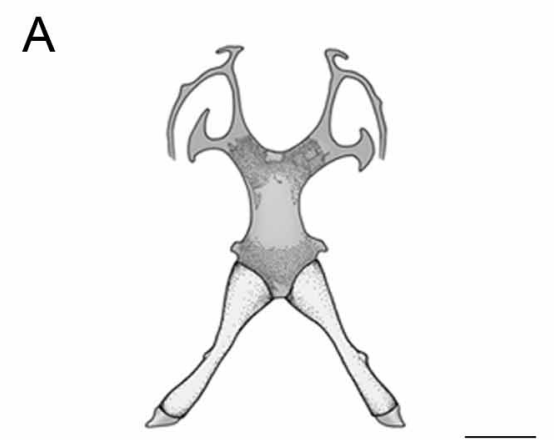

B

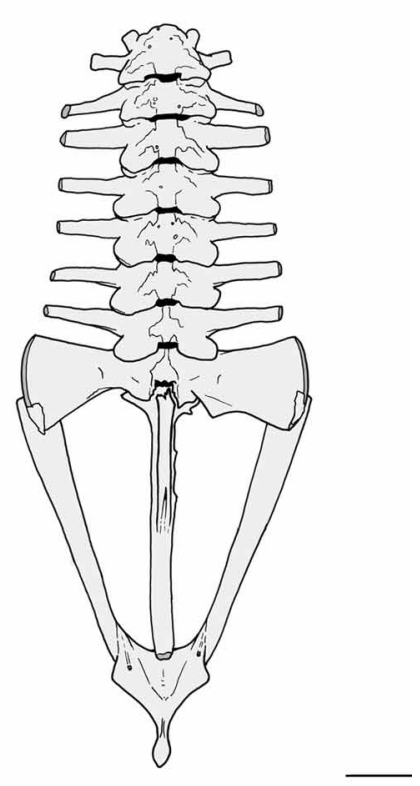

C
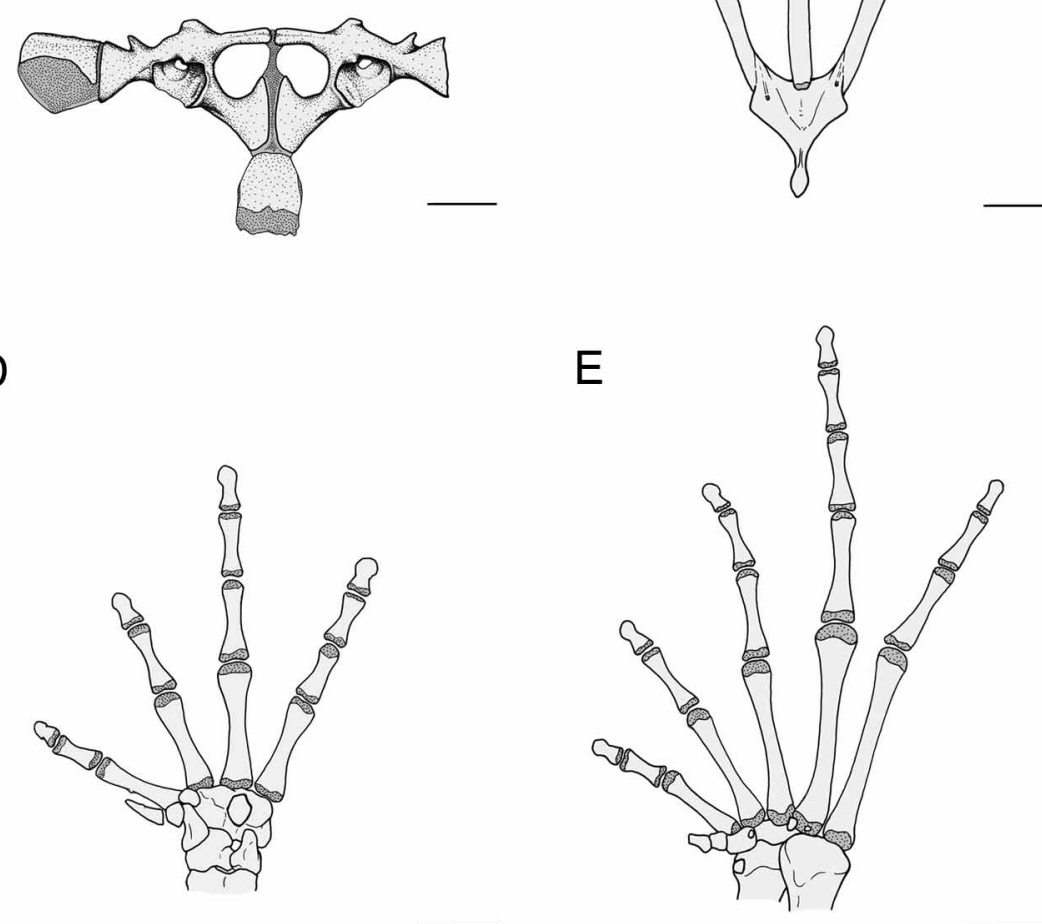

FIGURE 18.- Skeletal features of adult female Atelopus gigas from La Victoria, Departamento Nariño (KU 140318, $\mathrm{SVL}=54.5 \mathrm{~mm}$ ). (A) ventral view of hyobranchium, (B) dorsal view of vertebral column and pelvic girdle, (C) ventral view of pectoral girdle, (D) ventral view of manus, and (E) ventral view of pes. Cartilage is shown in gray. Scale of A-C $=4 \mathrm{~mm}$, scale of D-E $=2 \mathrm{~mm}$. Drawings by Diego A. Paucar.

The paired vomers are crescent-shaped, triradiate, edentate, and separated medially; the vomers are poorly developed in Atelopus gigas. The anterior ramus of the vomer is larger than the prechoanal ramus and is paral- 
lel to the midline; the terminus of the anterior ramus is pointed and as long as the prechoanal ramus in A. gigas and all A. ardila, except in KU 170108, in which the rami are truncate; in A. pastuso the prechoanal ramus varies from truncate (KU 166298-300) to pointed and small (KU 166296-97). Pre- and postchoanal rami surround the medial, antero-, and posteromedial margins of the choana. The prechoanal ramus is directed towards the maxillae, whereas the postchoanal ramus is either parallel to the midline or directed posterolaterally. The vomer is most reduced in A. gigas, whereas in A. ardila and A. pastuso it is slightly more developed.

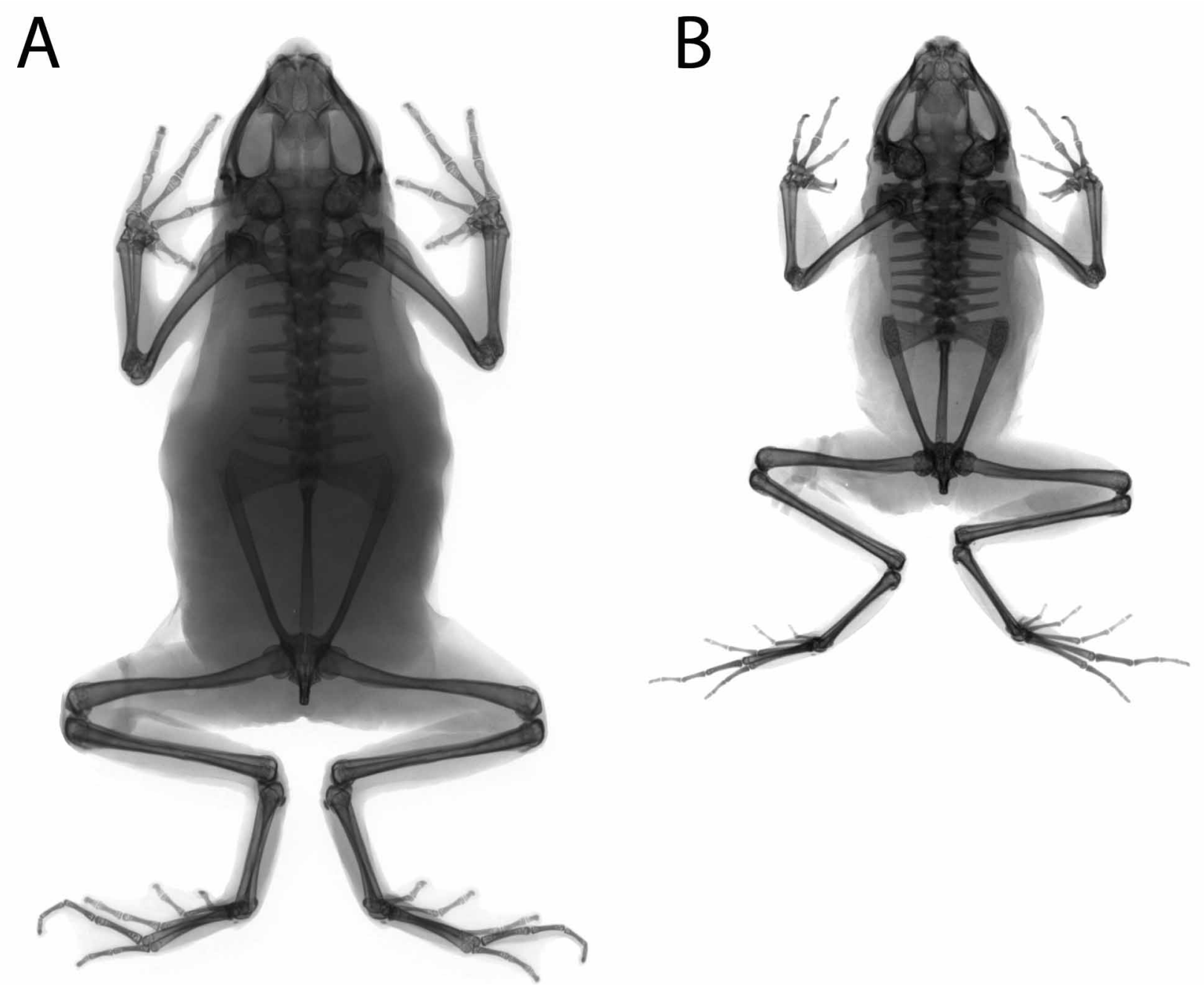

FIGURE 19.-Skeleton of holotype and paratype of Atelopus orcesi (MHNG 2684.75, 2559.67, respectively): (A) adult female, $\mathrm{SVL}=42.1 \mathrm{~mm}$; (B) adult male, $\mathrm{SVL}=29.4 \mathrm{~mm}$.

The neopalatine is a simple, unadorned, elongate, triangular, or subarcuate bone that underlies the planum antorbitale and sphenethmoid orbital margin; it extends from the sphenethmoid toward the maxilla, and is not visible in a dorsal view of the skull. A gap exists between the lateral margin of neopalatine and maxilla. The maxillary half of neopalatine is widest and its lateral border is usually pointed; the medial end is pointed, and the amount of overlap with sphenethmoid is variable. The neopalatine is subarcuate and elongated; the maxillary half varies bilaterally from truncate to pointed; the anterior border of the neopalatine is slightly rounded in Atelopus gigas. In A. ardila, the neopalatine varies from subtriangular (KU 200213) to cylindrical (KU 170107); the maxillary half is pointed medially and the anterior border is rounded, but the anterior margin in KU 169284 has an apex. In A. pastuso, the neopalatine varies from subtriangular (KU 166299-300) to subcylindrical (KU 166296-98); the maxillary half is pointed in all specimens, except KU 166296, in which it is pointed on one side and truncate on the other. 
A

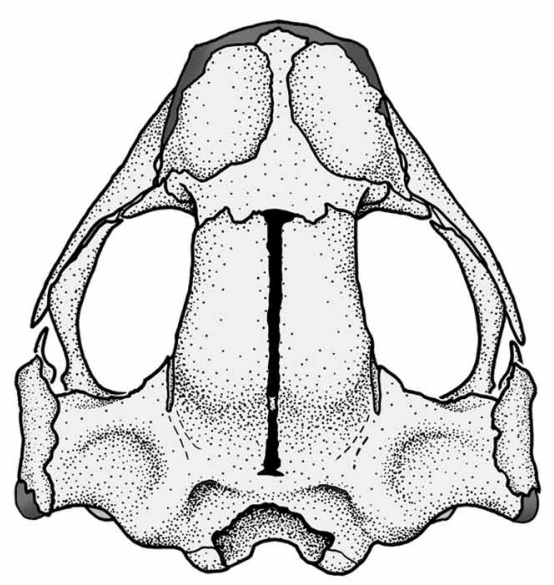

B

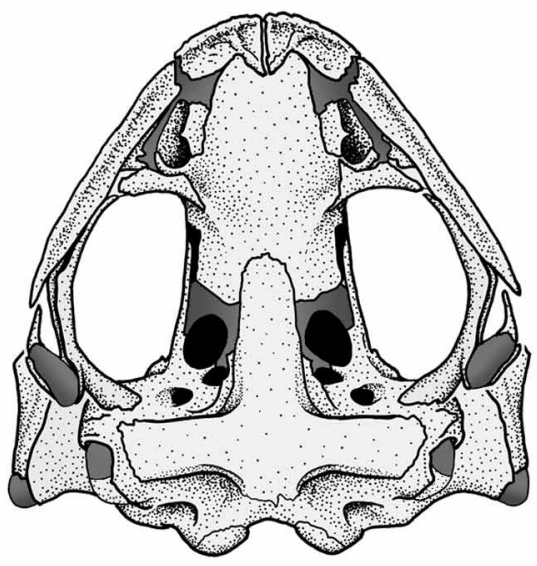

C

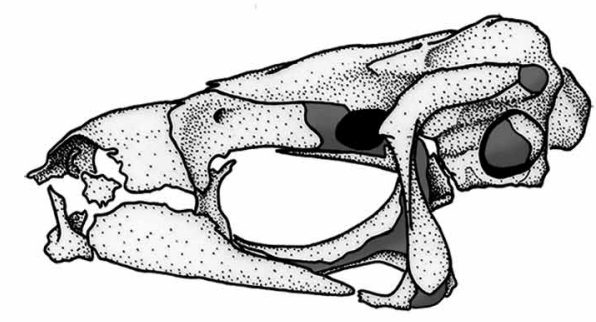

FIGURE 20.-Skull of adult female Atelopus pastuso from 20 km SW Tulcán, Provincia Carchi (KU 166298, SVL = $40.0 \mathrm{~mm}$ ). (A) dorsal and (B) ventral views. Scale $=2 \mathrm{~mm}$. Drawings by Diego A. Paucar.

The parasphenoid has an inverted T-shape and invests the ventral surface of the neurocranium; it extends from a level posterior to the neopalatines (from the anterior half of the orbit) toward, but not reaching the margin of the foramen magnum; its surfaces are smooth. The parasphenoid is broadly separated from the neopalatines. The cultriform process underlies the posterior part of the bony sphenethmoid. The lateral margins of the cultriform process are approximately parallel. The terminal end of the cultriform process is acutely pointed, but it varies in Atelopus pastuso from pointed (KU166299-300) to rounded (KU 166298). The parasphenoid alae are oriented perpendicular or slightly posterolateral to the cultriform process. The posterior margin of parasphenoid is rounded in A. gigas and A. ardila or straight and nearly straight in A. pastuso and A. podocarpus beneath the midwidth of the otic capsules. A medial posterior process is difficult to discern in A. gigas, one specimen of A. ardila (KU 170107), two specimens of A. pastuso (KU 166298 and 166300); if present in A. ardila, it varies in its shape from inverted subtriangular (KU 169292) to subrectangular (KU 200213, 170108) or bifurcate (KU 169284); in A. pastuso (KU166297 and 166299) and A. podocarpus, it is subrectangular.

The maxillary arcade is complete and lacks teeth on the premaxillae and maxillae. Each premaxilla consists of a dorsal alary process, a biradiate pars palatina, and an edentate pars dentalis forming the anterior margin. The two premaxillae are clearly separated medially. The alary process projects anterolaterally. In Atelopus gigas, the lower half of the alary process is as wide as the upper half; whereas in A. ardila it varies from as wide as (KU 169292, 170107) to wider than (KU 200213), in A. pastuso it is wider or slightly wider, and in A. podocarpus it is wider than the upper half. The pars palatina has two well-differentiated processes, a medial (palatine) and a lateral process; the lateral process is almost twice the length of the palatine process. The medial process of the pars palatina is a well-developed, triangular, pointed ramus, the length of its outer margin is more than half the medial edge length when projected in an imaginary line towards the middle. A foramen is present along the length of the medial process of the pars palatina, and a ridge is evident on its ventral surface. The inner margin of the pars palatina, where the palatine and lateral processes come together, 
forms an angular border, except in one specimen of A. ardila (KU 200213) where the border is slightly concave. The posterior end of the pars dentalis is nearly truncate, except in two specimens of A. pastuso (KU 166299-300), in which it is pointed; it articulates juxtaposed with the maxillae.

A

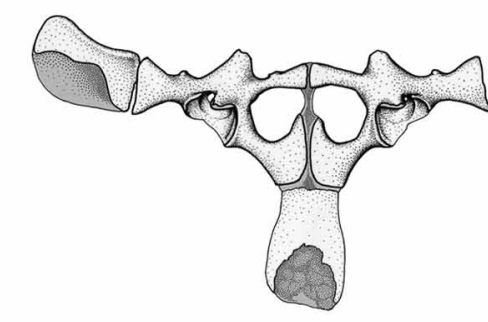

C

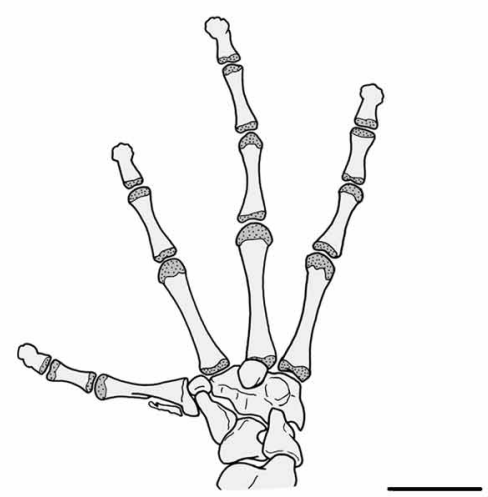

B

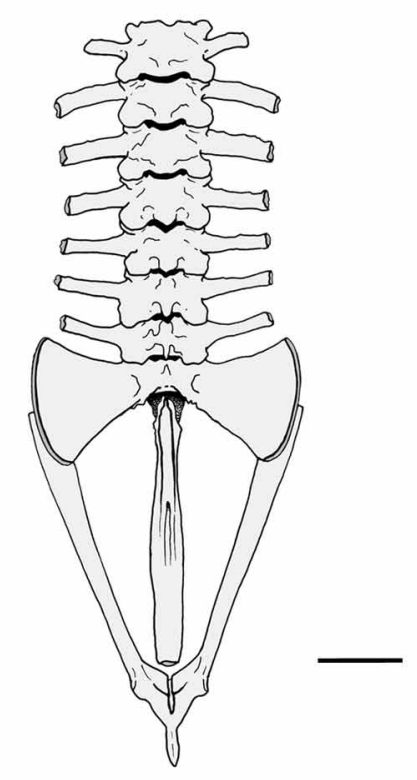

D

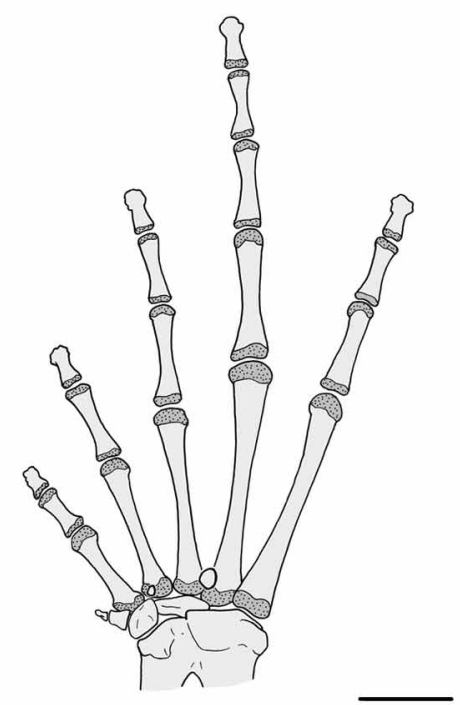

FIGURE 21.-Skeletal features of adult female Atelopus pastuso from $20 \mathrm{~km} \mathrm{SW}$ Tulcán, Provincia Carchi (KU $166298, \mathrm{SVL}=40.0 \mathrm{~mm}$ ). (A) ventral view of hyobranchium, (B) dorsal view of vertebral column and pelvic girdle, (C) ventral view of pectoral girdle, (D) ventral view of manus, and (E) ventral view of pes. Cartilage is shown in gray. Scale of $\mathrm{A}-\mathrm{C}=3 \mathrm{~mm}$, scale of $\mathrm{D}-\mathrm{E}=2 \mathrm{~mm}$. Drawings by Diego A. Paucar.

The maxilla is an elongate, edentate bone located between the premaxilla and the quadratojugal. A horizontal pars palatina of the maxilla extends along the lingual margin of the maxilla; posteriorly this shelf articulates with the anterior ramus of the pterygoid. The maxilla is deepest anteriorly and bears the pars facialis, which is directed medially and suboval in Atelopus gigas and A. podocarpus, either suboval (KU 200213, 170107), subrectangular (KU 169284, 169292) or subtriangular (KU 170108) in A. ardila, and subrectangular (KU 166300) or suboval (all other specimens) in A. pastuso; its dorsal margin is irregular in A. gigas, even in A. ardila and A. podocarpus, from nearly even (KU 166296) to slightly irregular (KU 166299) in A. pastuso, and not visible in A. orcesi. The anterior end of the maxilla is truncate, whereas the posterior end is pointed. The anterior end slightly overlaps the posterior end of premaxilla. The posterior end of the maxilla generally 
contacts or nearly contacts the quadratojugal, except in one specimen of A. pastuso (KU 166296) and in A. podocarpus.

The quadratojugal is a small, L-shaped bone underlying the margin of the ventral arm of the squamosal; the posterior ramus articulates with the pars articularis of the palatoquadrate and the anterior ramus is not reduced; thus it is nearly in contact or in contact with the maxilla.
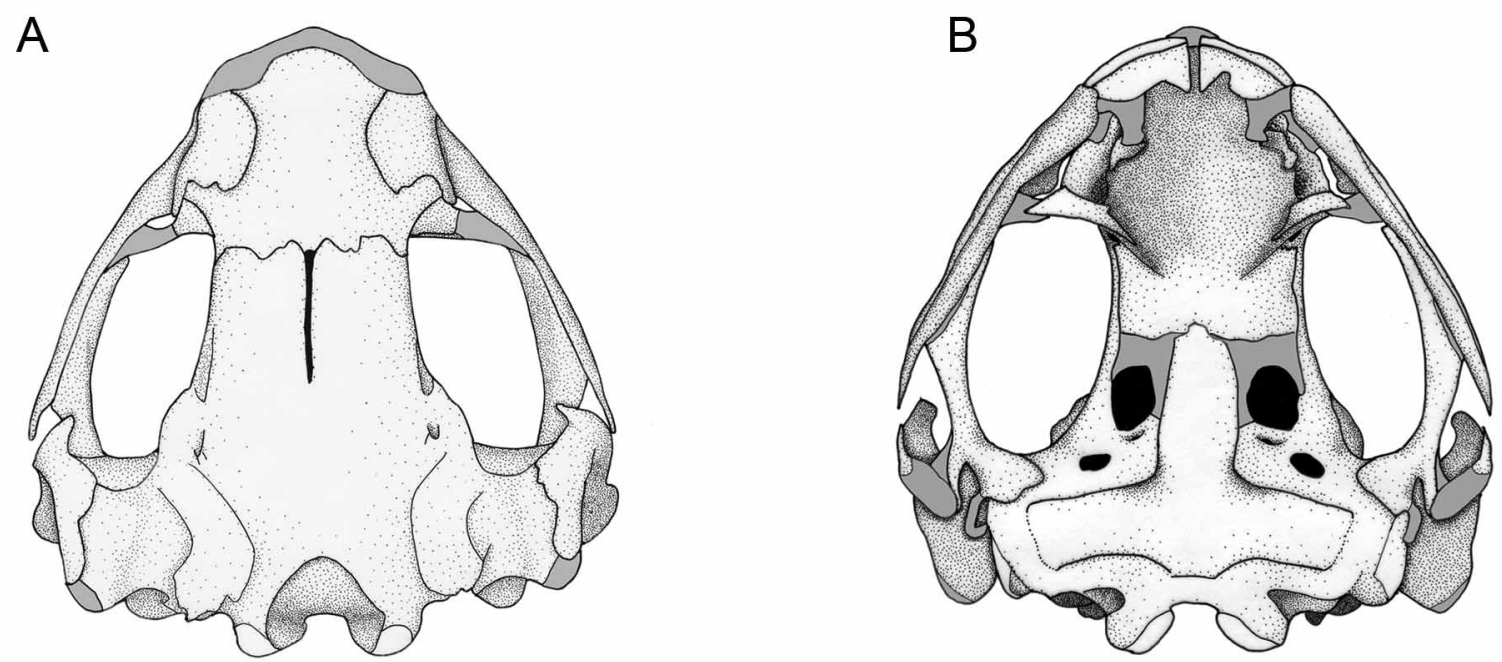

C

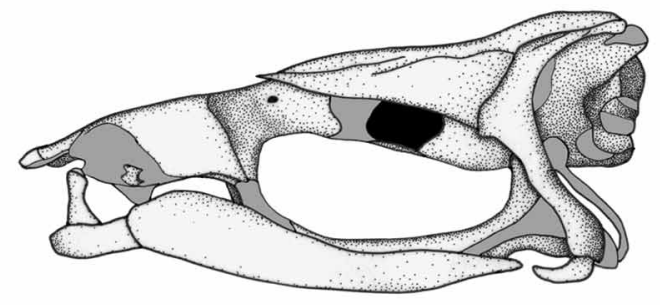

FIGURE 22.- Skull of adult female Atelopus podocarpus from Centro Administrativo Cajanuma, Parque Nacional Podocarpus, Provincia Loja (QCAZ 2838, SVL = $43.1 \mathrm{~mm})$. (A) dorsal and $(B)$ ventral views. Scale $=1 \mathrm{~mm}$. Drawings by Andrea Terán-Valdez.

The squamosal bears one or two dorsal rami, and a ventral ramus. The otic ramus (posterior, dorsal ramus) is moderately expanded towards the dorsolateral surface of the prootic; the otic ramus varies in the degree to which it overlaps the prootic; sculpturing on this element is absent. The otic ramus leaves just the posterior end of the prootic free, except in one specimen of A. ardila (KU 200213) where it extends for two thirds the length of the prootic; in A. podocarpus and A. pastuso it reaches three fourths the length of the prootic, except in one specimen of $A$. pastuso (KU 166292), where it reaches two thirds of that length. The zygomatic ramus is small and triangular, except for three specimens of $A$. ardila (KU 169284, 169292, 170107) that have a reduced zygomatic ramus. The angle between the dorsal part of the squamosal and the anterior margin of the dorsal portion of the ventral ramus is acute in A. gigas; it varies from slightly acute (KU 169292, 170107-08) to nearly perpendicular (KU 169284, 200213) in A. ardila and from acute (KU 166296-98) to nearly perpendicular (KU 166299-300) in A. pastuso. The lower portion of the ventral ramus is flat and blade-like and invests the palatoquadrate laterally. The squamosal has a keel that extends from the outer side of dorsal arm toward the outer, upper half of the ventral arm.

The triradiate pterygoid consists of anterior, medial, and posterior rami; the anterior ramus articulates with the maxilla anteriorly. The narrow space between the lateral margin of the anterior ramus and the maxilla is filled by the pterygoid cartilage. The medial and posterior rami of the pterygoid are about equal in length; however, the medial ramus is more robust than the posterior. The medial ramus invests the pseudobasal pro- 
cess of the prootic, and a short, posterior ramus invests the medial surface of the palatoquadrate. The articulation of the medial pterygoid ramus with the prootic involves two poorly differentiated heads that articulate with the ventrolateral surface of the pseudobasal process of the otic capsule.

The palatoquadrate is primarily cartilaginous and is invested by the ventral arm of the squamosal laterally and the posterior ramus of pterygoid medially and posteromedially. The ventral pars articularis associated with the quadratojugal is cartilaginous with a slight mineralization in Atelopus gigas.

The lower jaw is composed of four paired elements. Anteriorly, the mentomeckelian bone bears a cartilaginous medial margin that forms a symphysis with the opposite medial margin. Posteriorly the dorsal portion of the mentomeckelian bone is fused to the dentary; the latter is slender when viewed laterally. The edentate dentary overlaps the angulosplenial dorsally at the anterior portion and extends laterally toward the posterior region. The angulosplenial is located on the lingual surface of the mandible from a point behind one length of mentomeckelian bone and to the posterior end of the mandible. Between the dentary and angulosplenial a Meckel's cartilage extends from a point just behind the mentomeckelian bone to the posterior end of the mandible. Meckel's cartilage is invested by the dentary anterodorsally and anterolaterally, and by the angulosplenial posteroventrally and posteromedially. The dentary terminates posteriorly at a level anterior or just anterior to the beginning of the curve of angulosplenial.

Hyobranchium. (Figs. 16A, 18A, 21A, 23A). The hyobranchium consists of a cartilaginous plate, two hyalia, a pair of basally narrow alary (anterolateral) processes, usually a pair of posterolateral processes, and two ossified posteromedial processes. There is variation in shape of the plate (=corpus), as well as in the presence of the posterolateral processes. The plate is longer than wide in Atelopus gigas (ratio of hyoid plate length/hyoid plate minimum width 3.0, $n=1)$ A. ardila $(2.7-3.0, n=3)$, and A. podocarpus $(4.1, n=1)$. Endochondral mineralization in the corpus of hyoid plate is present in the anterior and posterior portion of corpus in A. gigas and absent in A. ardila and A. podocarpus. Each hyale bears a short anterior process, which may be straight or deflected laterally. The anterior process does not rejoin the hyale, except in one specimen of $A$. ardila (KU 200213). Atelopus gigas also bears a small process on the hyale lateral to the anterior process; in A. ardila and A. podocarpus this process is absent. As described by the configuration of the hyalia, the shape of the hyoglossal sinus varies; the lateral margins of the hyoglossal sinus are $U$-shaped in A. gigas; whereas in $A$. ardila and $A$. podocarpus these margins diverge forming a $\mathrm{V}$. The anterolateral processes always are present, and vary in shape. The narrow base in A. gigas and A. ardila supports an anterior flange and another slightly smaller posterior flange in A. gigas; the posterior flange is nearly absent in A. podocarpus; in A. ardila the flanges are not visible (KU 169284), not well developed and about the same size (KU 169292), or the posterior flange is slightly larger than the anterior flange (KU 200213). Posterolateral processes are present and small in A. gigas, whereas in A. podocarpus they are absent, in A. ardila they are either absent (KU 169284, 200213), small (KU 169292), or a small bump on one side (KU 169284, 200213). The long, bony posteromedial processes are cartilaginous terminally. The posteromedial processes bears a small lateral expansion at about half its length at one side in A. gigas, whereas in A. podocarpus it is absent; in A. ardila, it is either absent (e.g., KU 169284, 200213) or present (KU 169292).

Pectoral girdle. (Figs. 16C, 18C, 21C, 23C). Each half of the firmisternal pectoral girdle is composed of the suprascapula, scapula and zonal area. The cartilaginous suprascapula is fan shaped and nearly completely mineralized in Atelopus gigas and A. podocarpus; in A. ardila it is slightly mineralized, except in one specimen (KU 170108), in which it is only cartilaginous; in A. pastuso it varies from slightly (KU 166296) to heavily mineralized (KU 166299); and in A. orcesi is not visible. A bony, bicapitate cleithrum is present on the anterior margin of the suprascapula. The cleithrum is L-shaped, with the elongate arm located along the anterior margin and the short arm along the scapular border of suprascapula. The scapula is short and stocky, and fused to the clavicle and coracoid at its medial end. The pars acromialis and pars glenoidalis of scapula are not well defined; but their margins are evident by virtue of a separation zone that forms a small oval fenestra located at the inner margin of glenoid cavity. A prezonal element (= omosternum) is absent. Zonal components are clavicles, procoracoids, coracoids and epicoracoids. The clavicle is oriented transversely or slightly anteromedially; it is fused at its distal end with the pars acromialis of the scapula and distal end of coracoid, the medial tips are distinctly separated from one another. 
A

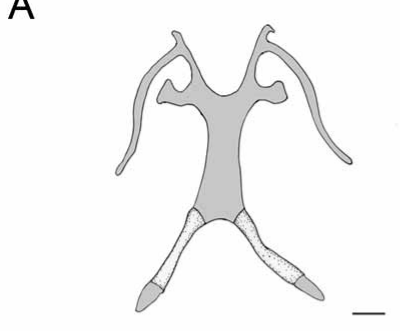

C

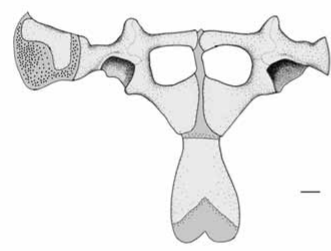

D

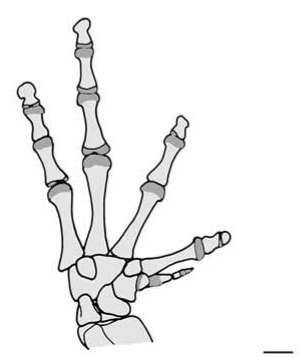

B

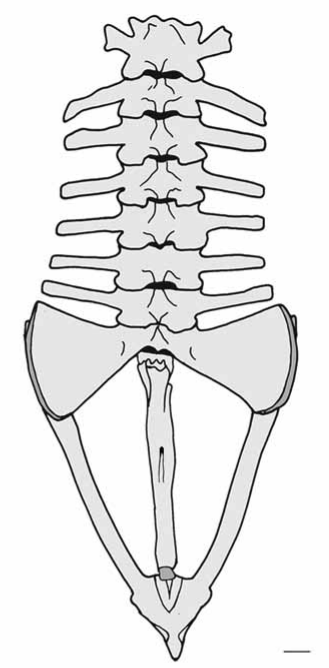

E

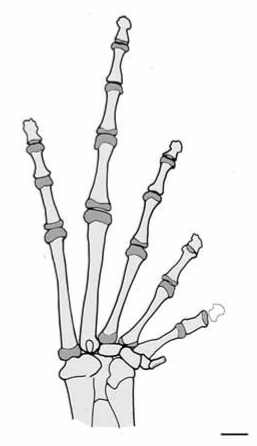

FIGURE 23.-Skeletal features of adult female Atelopus podocarpus from Centro Administrativo Cajanuma, Parque Nacional Podocarpus, Provincia Loja (QCAZ 2838, SVL $=43.1 \mathrm{~mm}$ ). (A) ventral view of hyobranchium, (B) dorsal view of vertebral column and pelvic girdle, and (C) ventral view of pectoral girdle, (D) ventral view of manus, and (E) ventral view of pes. Cartilage is shown in gray. Scale of A-E $=1.2 \mathrm{~mm}$. Drawings by Andrea Terán-Valdez.

The coracoid is stout, with the sternal end much more expanded than the glenoid end. The pectoral fenestra is oval and slightly wider than deep. The pectoral fenestra is oval in Atelopus podocarpus and slightly wider than deep, whereas it is subrounded in A. ardila, A. gigas, and A. pastuso. At midline, the epicoracoid cartilages are synchondrotically fused throughout their lengths and lack any trace of a suture. Anteriorly, at midregion, the epicoracoids are fused to procoracoid cartilages and form an epicoracoid bridge. Posteriorly, the mineralized epicoracoid cartilages are not fused to the sternum. A suture line is visible between the platelike epicoracoids and the sternum, where a triangular mineralized zone exists. A calcified procoracoid cartilage extends from the midlength to the medial end of the clavicles; the clavicle borders the procoracoid cartilage dorsally and ventrally. The epicoracoids and coracoids form the medial margin of the pectoral fenestra.

Other differences in the pectoral girdle include the degree of development of processes along the anterior margin of the clavicle and scapula, and the length and shape of the sternum. There are two triangular processes; the proximal clavicular acromium is larger than the distal. The former lies at the joint between the clavicle and scapula; its orientation forms an angle in Atelopus gigas and A. podocarpus; in A. ardila and A. pastuso it varies from nearly perpendicular to angular, in $A$. orcesi is nearly perpendicular. The distal process is well differentiated and triangular in A. gigas and A. ardila, except in KU 170107, in which it is very small; in A. pastuso it is nearly absent (KU 166297) or small and triangular (KU 166300); in A. orcesi and A. podocarpus it is nearly absent. 
The sternum varies in length. The ratios of sternum length to total length of girdle at midline are 0.39$0.55(n=5)$ in Atelopus ardila, $0.41(n=1)$ for A. gigas, 0.42-0.51 $(n=5)$ for A. pastuso, and $0.51(n=1)$ for A. podocarpus. There is no clear differentiation between a mesosternun and a xiphisternum. The sternum is entirely calcified; its distal cartilaginous terminus is nearly completely mineralized in A. gigas and A. podocarpus, and it is more mineralized in KU 170108 and less mineralized in KU 169292 of A. ardila; in A. pastuso, it is less mineralized in KU 166297 and more so in KU 166299. The sterna are expanded; ratios of sternum maximum width to sternum minimum width are 1.47-1.79 $(n=5)$ in A. ardila, $1.8(n=1)$ in A. gigas, and 1.36-1.86 $(n=5)$ in A. pastuso, $1.9(n=1)$ in A. podocarpus. The terminal end of the sternum is noticeable bifurcate in A. pastuso and A. podocarpus, and less pronounced in A. ardila and A. gigas; in A. orcesi it is not visible.

Pelvic girdle. (Figs. 16B, 18B, 19B, 21B, 23B). The pelvic girdle is V-shaped in dorsal aspect in the three species; it is composed of paired ilia, ischia, and pubes. The ilial shafts are cylindrical, lack crests, and have cartilaginous tips anteriorly. Each ilium extends anteriorly beneath the sacral diapophysis; the distal end of the ilium does not reach the anterior border of the diapophysis, its articulation to the outer margin of sacrum varies form about half the length to nearly the posterior margin. Posteriorly, the ilia are united in a medial symphysis with the ischia and pubes; the pubis is ossified. The iliosacral articulation is Type IIA (sensu Emerson 1979), thus the ilium is attached to the diapophysis by a broad, transverse ligament.

Vertebral column. (Figs. 16B, 18B, 19B, 21B, 23B). The vertebral column contains nine elements. The atlas complex is formed by the complete fusion of Presacrals I and II. There are six independent trunk vertebra (Presacrals III-VIII), the sacrum, and the coccyx. Vertebral centra are procoelus, and the sacrum bears a bicondylar articulation with the coccyx. The holochordal centra are cylindrical and solid. The neural arches of Presacrals IV-VIII are not imbricate.

In the atlas complex, one pair of transverse processes is present, and they are oriented anterolaterally. In Presacrals II-VIII, the anterior and posterior margins of the transverse processes are even (not crenulate). The proximal ends of the transverse processes are slightly wider than the terminal ends owing to the presence of a flange, which diminishes in size distally, except in Atelopus pastuso and A. podocarpus, in which flanges are nearly absent, thereby making the transverse processes equally wide along their lengths. The transverse processes are slightly shorter than the sacral diapophyses and their ends form a nearly straight line parallel to midline in A. gigas and A. orcesi; in A. ardila, the line is variably concave, being less concave in KU 169292 and more concave in KU 170108; in A. pastuso, the line varies from slightly concave (KU 166300) to nearly straight (KU 166297); in A. podocarpus is slightly concave. The transverse processes of Presacral III are the shortest and Presacral VIII is the largest in A. gigas; in A. ardila, Presacral III is the longer in all specimens, except in KU 169284 in which the longest is Presacral IV, followed by Presacral IV (KU 170107-08), V (KU 169284), VII (KU 169292) or VIII (KU 200213) and then followed by Presacral VIII in all specimens; in $A$. pastuso, Presacral III is longest, except in KU 166297 in which Presacral VIII is the longest, followed by Presacral IV (KU 166298-300), VII (KU 166297) or VIII (KU 166296), and then followed by III (KU 166297), V (KU 166299), VII (KU 166297-98) or VIII (KU 166300); in A. podocarpus, presacrals III and IV are the shortest and VIII the longest; in A. orcesi, presacrals III and IV are slightly shorter than the others, which are about the same length. Orientation of the transverse processes varies markedly. The processes of Presacrals IV-VIII are directed laterally in A. gigas; in A. ardila, the processes of Presacrals IV-VII are directed laterally or tend to be inclined posterolaterally, and Presacral VIII is slightly inclined anterolaterally; in A. pastuso, the processes are directed laterally, except on Presacral V in which they are inclined posterolaterally and on Presacral VIII anterolaterally; in A. orcesi and A. podocarpus, the processes are directed laterally, except on Presacral VIII, in which they are inclined anterolaterally. In A. ardila, A. orcesi, and A. pastuso, the spacing among transverse processes between vertebrae varies intraspecifically because of sexual dimorphism; males have smaller spaces than females. The neural spines are not elevated. Sculpturing on the dorsal surfaces of neural arches is indistinct. A central pit in most vertebrae and scattered small pits are absent.

The shape of the sacrum varies and is related to the sacral diapophyses, which are expanded. The anterior and posterior borders are nearly straight in Atelopus gigas, whereas in A. ardila the borders vary from nearly straight (KU 200213) to angular (KU 170107); in A. pastuso the borders are angular, being most angular in 
KU 166296. In A. orcesi the borders are angular except the anterior border of the male that is straight; in $A$. podocarpus the borders are angular. The sacrococcygeal articulation is not fused. The coccyx is an elongate, subcylindrical bone that is about $75 \%$ the length of the presacral portion of the vertebral column; it has an inverted triangular anterior end, which is formed by small vestigial lateral processes. Lateral processes are present in A. gigas, whereas they are absent in A. pastuso and A. podocarpus; in A. ardila they are either present (KU 169284, 169292) or absent (KU 200213, 170107-08), and in A. orcesi they are present in the male or absent in the female. A sesamoid bone in the posterior portion of outer margin of sacral dyapophysis is present in A. gigas. Lateral flanges along nearly entire length of coccyx are absent on the coccyx.

Forelimb. (Figs. 16D, 18D, 19A-B, 21D, 23D). A humerus, radioulna, carpal elements, four digits (II-V), and a prepollex make up the forelimb. Intercalary elements are absent. Torsion is absent in Digit II. The following carpal elements were observed: a postaxial centrale (= radiale), an ulnare, the Element Y, distal Carpals 3, 4, and 5 fused into a single bone, and distal Carpal 2. Additionally, two other elements were identified (Sesamoids I, and II sensu Coloma 2002). Sesamoid I is under distal Carpal 3+4+5; it is round. Sesamoid II is a smaller, round bone located at the distal end of the radius at the posterior upper side of the postaxial centrale. Terminal phalanges on the digits are knobbed-shaped. The phalangeal formula is 2-2-3-3. In increasing order of length, the order of the digits on the hand is II-III-V-IV. The prepollex is calcified. It possesses two and three elements in left and right hands, respectively in Atelopus gigas, two elements in A. pastuso, and exhibits sexual dimorphism in A. ardila. Males of A. ardila have two elements; the female (KU 169292) has three elements - two distal cartilaginous; the basal is fused to the proximal edge of the first phalange in both sexes. In A. pastuso, females have a thinner prepollex than males; the basal element of prepollex is fused in all except one specimen (KU 166296). In A. podocarpus, the prepollex is composed of five elements; the two distal are cartilaginous.

Hind limb. (Figs. 16E, 18E, 19A-B, 21E, 23E). The hind limb consists of a femur, tibiofibula, calcified cartilago plantaris, tarsal elements, five metatarsals, five digits, and a prehallux. The tarsal elements include the tibiale (= calcaneum), fibulare (= astragalus), Tarsal 1, Tarsals $2+3$ (fused), centrale, and the os sesamoides tarsale. Atelopus gigas has os sesamoides tarsale I and II: I is located ventral to the distal head of fibulare and II is ventral to tibiale. They are elliptical to round in shape; Os sesamoides tarsale I has two and one segments in the right and left foot, respectively, and Os sesamoides tarsale II have three and one segments in the right and left feet, respectively. The same bones are also present in the other two species. In A. ardila, Os sesamoides tarsale I has one segment, whereas II is absent (KU 20013, 169292, 169284 in left foot) or present with one (KU 170107, 169284 in right foot) or two segments (KU 170108). In A. pastuso, Os sesamoides I is present with one segment, but absent in KU 166299 and the left foot of KU 166296; II is either absent in KU 166297 and right foot of KU 166298, or present with one segment, except in KU 166300 that has two segments. The phalangeal formula of the pes is 2-2-3-4-3. In increasing order of length, the order of the digits on the foot is I-II-III-V-IV. The prehallux is ossified with two bony elements in female A. gigas. In A. ardila, it varies from three cartilaginous phalanges (KU 169292) to three ossified phalanges (KU 200213). In A. pastuso, it varies from one mineralized phalange (KU 166297) to three ossified phalanges (KU 166300, right foot). In A. orcesi, it is not visible. In A. podocarpus, it is represented by a bony, rounded basal element associated with a distal elongated element with a cartilaginous lateral edge.

\section{Discussion}

New species described herein belong to the genus Atelopus as defined by Cannatella (1986), Graybeal and Cannatella (1995), and Coloma (1997), based on the following putative synapomorphies: nonreduction of the quadratojugal, fusion of presacrals I and II, having a $\mathrm{V}$-shaped pelvic girdle, and presence of a gastromyzophorous tadpole, although the latter is only known in A. ardila sp. nov.

Species delimitation has been challenging in the genus Atelopus because of the difficulties associated with numerous kinds of variation (e.g. Lötters 1996). Herein, we have tried to use an integrative approach to taxonomy and avoid fuzzy boundaries by providing quantitative and discrete characters (Dayrat 2005, Jarrín-V and 
Kunz 2008). Nonetheless, we acknowledge that this is an active area of research that is at its beginnings, as emerged from the symposium of species delimitation held at the meettings of the Society for the Study of Evolution held at Stony Brook, USA, in 2006 and that were summarized by Wiens (2007). In the case of $A$. ardila and $A$. gigas we use quantitative morphological characters in addition to qualitative ones. In other cases, such as those of $A$. pastuso and A. podocarpus, the recognition of species is enhanced by genetic data and a phylogeny-based delimitation of species boundaries (Guayasamin et al. 2010). For A. orcesi, we rely on the distinctiveness of its morphology (see discussion in next paragraph) and an apparently large geographic gap between it and similar taxa. Nonetheless, in A. orcesi a possible source of error is the small sample size (only a male and female) and the absence of genetic and other kinds of data. Unfortunately, the possible extinction of $A$. orcesi, and four new species described herein imposes severe limits to the kind of data available for analyses and hypotheses testing.

Regarding intraspecific variation, two morphological features are remarkable. Spacing among transverse lateral processes of vertebra (as a result of size of vertebra) is sexually dimorphic in Atelopus ardila, A. pastuso, A. orcesi, A. podocarpus, as has also been reported for A. guanujo (Coloma 2002:Fig. 13), and this feature accounts for differences in SVL between sexes. In males of $A$. orcesi, its distinctiveness from other taxa is emphasized by an uncommon feature in Atelopus, the presence of a dorsolateral row of warts from the supraescapular to inguinal regions. This feature is known only in the Ecuadorian A. orcesi and four species from the Sierra Nevada de Santa Marta in Colombia and the Venezuelan Andes-A. laetissimus, A. mucubajiensis, A. nahumae, and A. pinangoi. In males, this feature might be sexually dimorphic in A. orcesi, but that remains questionable until more specimens become available. Also, it is unlikely that this feature indicates a close relationship with $A$. orcesi and taxa in northern Colombia and Venezuela, given the large geographic gap between $A$. orcesi and the other species; an independent origin in A. orcesi seems to be more likely.

Hybridization is a natural phenomenom documented in a wide variety of taxa; it is more common in plants than in animals (Mallet 2007). Its occurrence in amphibians has been documented in a few taxa (Szymura 1993, Lemmon et al. 2007) but not studied in Atelopus. More recently, some evidence of hybrid zones occurring between A. exiguus and A. bomolochos and among members of the A. spumarius and A. flavescens complexes has been suggested (Lötters 1996; Coloma et al. 2000; Noonan and Gaucher 2005). Herein we hypothesize the occurrence of a hybrid zone between A. ignescens and A. pastuso based on: (1) polymorphism and intermediate morphologies found in a narrow zone $\left(26.4 \mathrm{~km}^{2}\right)$, as compared to the larger zones of the parental distributions (A. pastuso $=3128 \mathrm{~km}^{2}$; A. ignescens $=7691 \mathrm{~km}^{2}$ ), and (2) information on the phylogenetic relationships between these two taxa (Coloma 1997, Guayasamin et al. 2010). According to the phylogeny, this hypothetical hybrid zone would be the result of either primary or secondary contact; because $A$. pastuso ( = A. "guachucal" of Gray 1983) is either genetically distant from A. ignescens (Guayasamin et al. 2010) or is not the sister taxon of A. ignescens (Coloma 1997).

\section{Diversity and Conservation}

This paper adds to a practice, which is being called "forensic taxonomy" by Mendelson III and Mulcahy (2010). Descriptions of new species raise the number of Atelopus currently described to 92 species, but also raise the number of species that are possibly extinct. For example, only in Ecuador there are about 14 species of Atelopus that are possibly extinct (updated from Ron et al. in press). We categorize five species treated herein as Critically Endangered (Possibly Extinct). Atelopus gigas is categorized as Data Deficient because no collecting efforts have been carried out at their only known locality; nonetheless, a similar fate of severe declines or extinction is a reasonable assumption given the commonality of extinction trends of highland Atelopus.

The first alerts of the decline and possible extinctions of frogs attracted wide attention in 1990 (Barinaga 1990; Blaustein and Wake 1990). A decade and a half latter, Stuart et al. (2004) and La Marca et al. (2005) confirmed catastrophic declines and possible extinctions of Atelopus. According to the latter, of 113 species (including undescribed) of Atelopus at least $27 \%$ (30 species) were feared extinct, $37 \%$ (42 species) declined, $9 \%$ (10 species) had stable populations, and $27 \%$ (31 species) were Data Deficient. During the Amphibian 
Conservation Summit held in Washington D.C. in 2005 the magnitude of the amphibian crisis was further recognized and, as a result, the IUCN Amphibian Conservation Action Plan (Gascon et al. 2007) guided a series of actions, including emergency responses to save species under the greatest threat. Some of these actions were directed to localized populations of Atelopus in order to carry out conservation measures (Hoffmann et al. 2008; Zippel and Mendelson 2008). More recently, Lötters (2007) provided a synopsis of Atelopus threats and insisted on a synchronous multidisciplinary approach to increase survival chances of species of Atelopus. Regrettably, results are discouraging because few individuals of only $\sim 30$ species out of $\sim 120-150$ species (92 described plus 30-70 undescribed) of Atelopus have been located since 2005 although sustainable sampling efforts are still needed in remote areas, as claimed by Lötters et al. (2005). Among the $\sim 30$ species, there is evidence of the maintenance of populations that contain abundant individuals only for five mostly lowland species: A. cruciger, A. flavescens Duméril and Bibron, A. hoogmoedi Lescure, A. gracilis Barbour ( = Atelopus elegans gracilis), and A. pulcher (Rueda-Almonacid et al. 2005; Luger et al. 2008; von May et al. 2008; Lötters, pers. com.). In addition, only one species (Atelopus zeteki) is being captive reared on the basis of sufficient founder individuals (Poole 2008). These scenarios show that responses and actions in the fields of science, conservation, and policies have failed, and currently are far from being successful. Priority actions and conservation measures remain in the realm of rhetoric, and are not proactive in practice. Extinctions of Atelopus (and other anurans) are beyond control and are increasingly exacerbated by global warming (Kiesecker $e t$ al. 2001; Pounds and Coloma 2008; Pounds et al. 2006), pathogens (Daszak et al. 2003; Lips et al. 2008), a cocktail of other factors (Collins and Storfer 2003, Collins and Crump 2009), plus the perennial lack of funds for research and conservation in Neotropical countries, and the largely unfilled gap between theory and practice in conservation biology (Nature Editorial 2007; Chan 2008; Chapron and Arlettaz 2008).

\section{Acknowledgments}

For the loan of specimens and data we thank Jean Mariaux and Andreas Schmitz (MHNG), John D. Lynch and the late Pedro M. Ruiz-Carranza (ICN). Antonio W. Salas graciously ceded to us the description of Atelopus podocarpus, on which he had planned to work. Fieldwork, in Ecuador and Colombia, was supported by grants from: the National Science Foundation (to WED, P. I.; throughout the project "Patterns of speciation and biogeography of Andean anurans", BSR 8805920), the MHNG (to Giovanni Onore at PUCE); the Consejo de Universidades y Escuelas Politécnicas del Ecuador (to AA, P. I.; throughout the project "Contribución al conocimiento de la herpetofauna del piso Altoandino", CONESUP 85-05); the Panorama Society Fund, Natural History Museum, and the Graduate Student Research Fund of the Department of Systematics and Ecology of The University of Kansas (to LAC). A visit in 2008 to review collections at KU by LAC was made possible by funds from PUCE and the Saint Louis Zoo. The Ecuadorian Ministerio de Agricultura y Ganadería provided research and collecting permits during 1985, 1989, and 1990 (4 PNF-ANVS, 043 IC PRONAF, and 60 DNF-ANRS). We are indebted to many field companions, who also provided assistance and logistic support during field trips (they are indicated in the collection data of specimens); LAC also is especially indebted to Giovanni Onore for his encouragement and support, WED graciously thanks his field companions on several trips in the Andes of Colombia and Ecuador- Patricia A. Burrowes, Dana T. Duellman, David M. Hillis, Bruce MacBryde, John E. Simmons, and Linda Trueb. We are grateful to Diego A. Paucar for drawing illustrations of skeletal features depicted on Figures 11-19; Pablo Menéndez-Guerrero for georeferencing localities, extracting climate information, statistical advice, and the identification of prey in Atelopus gigas and A. pastuso; Mónica I. Páez and Wladimir Carvajal for help on the identification of prey in A. pastuso; M. Belén Baus for help on georeferencing localities and editing Figure 5. Eugenia M. del Pino permitted use of her laboratory notes and photos of A. pastuso. John D. Lynch collected many specimens and also provided valuable information and a photo of $A$. angelito. Ítalo G. Tapia helped in numerous curatorial matters and to photograph type specimens. Charles Linkem helped to photograph the specimen of Atelopus angelito depicted in Figure 10. Humberto Moreno Estrella did the holotype virtual animations. Stefan Lötters and Joseph R. Mendelson III reviewed the ms and provided helpful comments. Fernando Castro generously helped to locate 
a difficult literature reference. Mónica I. Páez and Juan Fernando Dueñas helped in taking some merisitc data of A. pastuso, editing literature references, and in numerous tasks in the final stages of writing this manuscript. These final stages were funded to QCAZ by Secretaría Nacional de Ciencia y Tecnología del Ecuador throughout the project "Inventario y caracterización genética y morfológica de la diversidad de anfibios, reptiles y aves de los Andes del Ecuador", PIC-08-0000470. This manuscript is part of the systematics component of the program for research of native amphibians of the Project "Balsa de los Sapos" (Life Raft for Frogs), which is part of the strategic plan for the conservation of the Ecuadorian amphibians in risk of extinction.

\section{References}

Adler, K. (2007) Orcés V., Gustavo (1903-1999). In: Adler, K. (Ed.) Contributions to the History of Herpetology. Society for the Study of Amphibians and Reptiles, Dexter, USA, 394 pp.

Albuja, V.L. (2004) Dr. Gustavo Orcés Villagómez (1903-1999). Politécnica, 25, 7-10.

Almendáriz, A. (2005) Atelopus sp. 15. In: Rueda-Almonacid, J.V., Rodríguez-Mahecha, J.V., Lötters, S., La Marca, E., Kahn, T. \& Angulo, A. (Eds.) Ranas arlequines. Conservación Internacional. Panamericana Formas e Impresos S. A., Bogotá, Colombia, 151 pp.

Almendáriz, A. \& Cisneros, D. (2005) Atelopus sp. 17. In: Rueda-Almonacid, J.V., Rodríguez-Mahecha, J.V., Lötters, S., La Marca, E., Kahn, T. \& Angulo, A. (Eds.) Ranas arlequines. Conservación Internacional. Panamericana Formas e Impresos S. A., Bogotá, 153 pp.

Alméndariz, A. \& Orcés, G. (2004) Distribución de algunas especies de la herpetofauna de los pisos: altoandino, temperado y subtropical. Politécnica, 25, 97-150.

AmphibiaWeb. (2009) AmphibiaWeb: information on amphibian biology and conservation. [Web application] 8 June 2009. University of California Berkeley. Berkeley, California: AmphibiaWeb. Available from http://amphibiaweb.org (Accessed 2 July 2009).

Ardila-Robayo, M.C. (2005) Atelopus angelito. In: Rueda-Almonacid, J.V., Rodríguez-Mahecha, J.V., Lötters, S., La Marca, E., Kahn, T. \& Angulo, A. (Eds.) Ranas arlequines. Conservación Internacional. Panamericana Formas e Impresos S. A., Bogotá, Colombia, 56 pp.

Ardila-Robayo, M.C. \& Maldonado-Silva, R.A. (2004) Sapito arlequín de Nariño <<Atelopus ignescens >>. In: RuedaAlmonacid, J.V., Lynch, J.D., \& Amézquita, A. (Eds.) Libro rojo de los anfibios de Colombia. Serie Libros Rojos de Especies Amenazadas de Colombia. Conservación Internacional Colombia, Instituto de Ciencias Naturales-Universidad Nacional de Colombia, Ministerio de Medio Ambiente, Panamericana Formas e Impresos S. A., Bogotá, Colombia, 384 pp.

Ardila-Robayo, M.C. \& Ruiz-Carranza, P.M. (1998) Una nueva especie de Atelopus A.M.C. Duméril \& Bribon 1841 (Amphibia: Bufonidae) de la Cordillera Central Colombiana. Revista de la Academia Colombiana de Ciencias Exactas, Físicas y Naturales, 83, 281-285.

Barinaga, M. (1990) Where have all the froggies gone? Science, 274, 1034-1035.

Blaustein, A.R. \& Wake, D.B. (1990) Declining amphibian populations: A global phenomenon? Trends in Ecology \& Evolution, 5, 203-204.

Cannatella, D.C. (1986) A new genus of bufonid (Anura) from South America, and phylogenetic relationships of the neotropical genera. Herpetologica, 42, 197-205.

Cañadas-Cruz, L. (1983) El mapa bioclimático y ecológico del Ecuador. Ministerio de Agricultura y Ganadería. Programa Nacional de Regionalización Agraria. Banco Central del Ecuador, Quito, Ecuador, 209 pp.

Cepeda-Quilindo, B. \& Rueda-Almonacid, J.V. (2005) Atelopus complejo ignescens. In: Rueda-Almonacid, J.V., Rodríguez-Mahecha, J.V., Lötters, S., La Marca, E., Kahn, T. \& Angulo, A. (Eds.) Ranas arlequines. Conservación Internacional. Panamericana Formas e Impresos S. A., Bogotá, 135 pp.

Chan, K.M.A. (2008) Conservation: in a rut, we need rut-inspired solutions. Nature 451, 127.

Chapron, G. \& Arlettaz, R. (2008) Conservation: academics should "conserve or perish". Nature 451, 127.

Collins, J.P. \& Storfer, A. (2003) Global amphibian declines: sorting the hypotheses. Diversity and Distributions, 9, 8998.

Collins, J.P. \& Crump, M.L. (2009) Extinction in Our Times: Global Amphibian Decline. 273 pp.

Coloma, L.A. (1997) Morphology, systematics and phylogenetic relationships among frogs of the genus Atelopus (Anura:Bufonidae). Ph. D. dissertation, Lawrence, University of Kansas. 287 pp.

Coloma, L.A. (2002) Two new species of Atelopus (Anura: Bufonidae) from Ecuador. Herpetologica, 58, 229-252.

Coloma, L.A., Lötters, S., Duellman, W.E. \& Miranda-Leiva, A. (2007) A taxonomic revision of Atelopus pachydermus, and description of two new (extinct?) species of Atelopus from Ecuador (Anura : Bufonidae). Zootaxa, 1557, 1-32. 
Coloma, L.A., Lötters, S. \& Salas, A.W. (2000) Taxonomy of the Atelopus ignescens complex (Anura : Bufonidae): Designation of a neotype of Atelopus ignescens and recognition of Atelopus exiguus. Herpetologica, 56, 303-324.

Daszak, P., Cunningham, A.A. \& Hyatt, A.D. (2003) Infectious disease and amphibian population declines. Diversity and Distributions, 9, 141-150.

Dayrat, B. (2005) Towards integrative taxonomy. Biological Journal of the Linnean Society, 85, 407-415.

Del Castillo Ch., B. (1982) Comportamiento reproductor y primeros estadios embrionarios de Atelopus ignescens (Cornalia). In: II Congreso Grancolombiano y VI Jornadas Nacionales de Ciencias Biológicas. Vol. I. Sociedad Ecuatoriana de Biología (ed.). Editorial Escuela Superior Politécnica del Litoral, Guayaquil, Ecuador. 127-132 pp.

Dingerkus, G. \& Uhler, L.D. (1977) Enzyme clearing of alcian blue stained whole small vertebrates for demostration of cartilage. Stain Technology, 52, 229-232.

Duellman, W.E. (1979) The herpetofauna of the Andes: Patterns of distribution, origins, differentiation, and present communities In: Duellman, W.E. (Ed.) The South American herpetofauna: Its origin, evolution, and dispersal. Monographs of the Museum of Natural History, The University of Kansas, Lawrence, 371-459 pp.

Duellman, W.E. \& Lynch, J.D. (1969) Descriptions of Atelopus tadpoles and their relevance to atelopodid classification. Herpetologica, 25, 231-240.

Duellman, W.E. \& Trueb, L. (1986) Biology of Amphibians. McGraw-Hill, New York, 670 pp.

Emerson, S.B. (1979) The ilio-sacral articulation in frogs: form and function. Biological Journal of the Linnean Society, $11,153-168$.

ESRI (2008) ArcMap v. 9.3. ESRI. California, USA.

Fabrezi, M. \& Alberch, P. (1996) The carpal elements of anurans. Herpetologica, 52, 188-204.

Frost, D.R. (2009) Amphibian Species of the World: an Online Reference. Version 5.3 (12 February, 2009). American Museum of Natural History. New York, USA. Available at: http://research.amnh.org/herpetology/amphibia/ index.html (accessed 8 June 2009).

Gascon, C., Collins, J.P., Moore, R.D., Church, D.R., McKay, J.E. \& Mendelson III, J.R. (2007) Amphibian Conservation Action Plan. Gland, IUCN/SSC Amphibian Specialist Group, 64 pp.

Gómez, C.L. \& Ramos, O.A. (1982) Alimento de las ranas Atelopus ignescens (Cornalia) de Nariño y Putumayo (Colombia). In: II Congreso Grancolombiano y VI Jornadas Nacionales de Ciencias Biológicas. Vol. I. Sociedad Ecuatoriana de Biología (ed.). Editorial Escuela Superior Politécnica del Litoral, Guayaquil, Ecuador. 167-173 pp.

Gómez Castillo, L. (1982) Aspectos ecológicos, morfológicos y de conducta de las ranas del género Atelopus del Departamento de Nariño, Colombia. Revista Humboldt, 1, 53-64.

Gómez Castillo, L. (1993) Aspectos de la ecología y ciclo vital de la rana Atelopus ignescens (Cornalia) de los alrededores del Lago Guamuez, Nariño Colombia. Revista de Investigaciones Universidad de Nariño, Pasto, 7(VI), 168177.

Gómez, L. \& Ramos, O.A. (1982) Contenido estomacal de Atelopus ignescens (Cornalia) de Nariño y Putumayo, República de Colombia. In: II Congreso Grancolombiano y VI Jornadas Nacionales de Biología. Vol. I. Sociedad Ecuatoriana de Biología (ed.). Editorial Escuela Superior Politécnica del Litoral, Guayaquil, Ecuador. 163-165 pp.

Gray, P. (1983) Morphometrics of the Atelopus ignescens Complex (Anura: Bufonidae). M. Sc. dissertation, Lawrence, University of Kansas. 225 pp.

Gray, P. \& Cannatella, D.C. (1985) A new species of Atelopus (Anura, Bufonidae) from the Andes of northern Peru. Copeia, 910-917.

Graybeal, A. \& Cannatella, D.C. (1995) A new taxon of Bufonidae from Peru, with descriptions of two new species and a review of the phylogenetic status of supraspecific bufonid taxa. Herpetologica, 51, 105-131.

Guayasamin, J.M. \& Trueb, L. (2007) A new species of glass frog (Anura: Centrolenidae) from the lowlands of northwestern Ecuador, with comments on centrolenid osteology. Zootaxa, 1447, 27-45.

Guayasamin, J.M., Bonaccorso, E., Duellman, W.E. \& Coloma, L.A. (2010) Genetic differentiation in the nearly extinct harlequin toads (Bufonidae: Atelopus), with emphasis on the Atelopus ignescens and A. bomolochos species complexes. Zootaxa, 2574, 55-68.

Hijmans, R.J., Cameron, S.E., Parra, J.L., Jones, P.G. \& Jarvis, A. (2005) Very high resolution interpolated climate surfaces for global land areas. International Journal of Climatology, 25, 1965-1978.

Hoffmann, M., Brooks, T.M., Da Fonseca, G.A.B., Gascon, C., Hawkins, A.F.A., James, R.E., Langhammer, P., Mittermeier, R.A., Pilgrim, J.D., Rodrigues, A.S.L. \& Silva, J.M.C. (2008) Conservation planning and the IUCN Red List. Endangered Species Research, 6, 113-125.

IUCN. (2001) Red list categories: version 3.1. UICN Species Survival Comission, Gland 30 pp.

IUCN Standards and Petitions Working Group. (2008) Guidelines for using the IUCN Red List Categories and Criteria. Version 7.0. (August 2008). Standards and Petitions Working Groups of the IUCN SSC Biodiversity Assesment Sub-Committe. Available from http://intranet.iucn.org/webfiles/doc/SSC/RedList/RedListGuidelines.pd (accessed 15 May 2009).

Jarrín-V, P. \& Kunz, T.H. (2008) Taxonomic history of the genus Anoura (Chiroptera: Phyllostomidae) with insights into the challenges of morphological species delimitation. Acta Chiropterologica, 10, 257-269. 
Kiesecker, J.M., Blaustein, A.R. \& Belden, L.K. (2001) Complex causes of amphibian population declines. Nature, 410 , 681-684.

La Marca, E., Lips, K.R., Lötters, S., Puschendorf, R., Ibañez, R., Rueda-Almonacid, J.V., Schulte, R., Marty, C., Castro, F., Manzanilla-Puppo, J., García-Perez, J.E., Bolaños, F., Chaves, G., Pounds, J.A., Toral, E. \& Young, B.E. (2005) Catastrophic population declines and extinctions in neotropical harlequin frogs (Bufonidae: Atelopus). Biotropica, 37, 190-201.

Lemmon, E.M., Lemmon, A.R., Collins, J.T., Lee-Yaw, J.A. \& Cannatella, D.C. (2007) Phylogeny-based delimitation of species boundaries and contact zones in the trilling chorus frogs (Pseudacris). Molecular Phylogenetics and Evolution, 44, 1068-82.

Lips, K.R., Diffendorfer, J., Mendelson III, J.R. \& Sears, M.W. (2008) Riding the wave: Reconciling the roles of disease and climate change in amphibian declines. PLoS Biology, 6, 441-454.

Lötters, S. (1996) The Neotropical Toad Genus Atelopus. Checklist - Biology - Distribution. M. Vences \& F. Glaw, Köln, Germany, $143 \mathrm{pp}$.

Lötters, S., Schulte, R., Córdova, J.H. \& Veith, M. (2005) Conservation priorities for harlequin frogs (Atelopus spp.) of Peru. Oryx, 39 (3), 343-346.

Lötters, S. (2007) The fate of the harlequin toads - help through a synchronous multidisciplinary approach and the IUCN “Amphibian Conservation Action Plan”. Mitteilungen Museum Für Naturkunde Berlin, Zoologische Reihe, 83, 6973.

Luger, M., Garner, T.W.J., Ernst, R., Hödl, W. \& Lötters, S. (2008) No evidence for precipitous declines of harlequin frogs (Atelopus) in the Guyanas. Studies on Neotropical Fauna and Environment, 43, 177-180.

Mallet, J. (2007) Hybrid speciation. Nature, 466, 279-283.

Mendelson III, J.R. \& Mulcahy, D.G. (2010) A new species of toad (Bufonidae: Incilius) from central Panama. Zootaxa, 2396, 61-68.

Merino-Viteri, A. (2001) Análisis de posibles causas de las disminuciones de poblaciones de anfibios en los Andes del Ecuador. Tesis de Licenciatura, Quito, Ecuador, Pontificia Universidad Católica del Ecuador. 66 pp.

Mueses-Cisneros, J.J. (2005) Fauna anfibia del valle de Sibundoy, Putumayo-Colombia. Caldasia, 27, $229-242$.

Nature Editorial. (2007) The great divide. Nature, 450, 136.

Noonan, B.P. \& Gaucher, P. (2005) Phylogeography and demography of Guianan harlequin toads (Atelopus): diversification within a refuge. Molecular Ecology, 14, 3017-3031.

Poole, V. (2008) Project golden frog. Endangered Species Bulletin, 33, 7-10.

Pounds, J.A., Bustamante, M.R., Coloma, L.A., Consuegra, J.A., Fogden, M.P., Foster, P.N., La Marca, E., Masters, K.L., Merino-Viteri, A., Puschendorf, R., Ron, S.R., Sánchez-Azofeifa, G.A., Still, C.J. \& Young, B.E. (2006) Widespread amphibian extinctions from epidemic disease driven by global warming. Nature, 439, 161-7.

Pounds, J.A. \& Coloma, L.A. (2008) Beware the lone killer: Why are harlequin frogs disappearing across the American tropics? A resifiting of the evidence backs up the conclusion that global warming is a key conspirator in the losses. Nature Reports Climate Change, Nature Publishing Group, 0804, 10.1038/climate.2008.37.

Rivera-Rosi, J. (2007) Parque Nacional Podocarpus. In: ECOLAP \& MAE (Eds.) Guía del patrimonio de áreas naturales protegidas del Ecuador. ECOFUND, FAN, Darwin Net, IGM, Quito, Ecuador, 185-192 pp.

Ron, S.R. \& Merino, A. (2000) Amphibian declines in Ecuador: overview and first report of chytridiomycosis from South America. Froglog, 42, 2-3.

Ron, S.R., Duellman, W.E., Coloma, L.A. \& Bustamante, M.R. (2003) Population decline of the Jambato toad Atelopus ignescens (Anura: Bufonidae) in the Andes of Ecuador. Journal of Herpetology, 37, 116-126.

Ron, S.R., Guayasamin, J.M., Coloma, L.A. \& Menéndez-Guerrero, P.A. (in press) Decline and conservation of amphibians in Ecuador. In: Heatwole, H., Barrio-Amoros, C. \& Wilkinson, J. (Eds.) Status of conservation and decline of amphibians. Surrey Beatty \& Sons Pty. Ltd., Australia, xx pp.

Rueda-Almonacid, J.V. (2005a) Atelopus sp. 16. In: Rueda-Almonacid, J.V., Rodríguez-Mahecha, J.V., Lötters, S., La Marca, E., Kahn, T. \& Angulo, A. (Eds.) Ranas arlequines. Conservación Internacional. Panamericana Formas e Impresos S. A., Bogotá, Colombia, 152 pp.

Rueda-Almonacid, J.V. \& Acosta, A.R. (2005) Atelopus sp. 6. In: Rueda-Almonacid, J.V., Rodríguez-Mahecha, J.V., Lötters, J.V., La Marca, E., Kahn, T. \& Angulo, A. (Eds.) Ranas arlequines. Conservación Internacional. Panamericana Formas e Impresos S. A., Bogotá, Colombia, 142 pp.

Rueda-Almonacid, J.V., Rodríguez-Mahecha, J.V., Lötters, S., La Marca, E., Kahn, T. \& Angulo, A. (Eds.). (2005) Ranas arlequines. Conservación Internacional. Panamericana Formas e Impresos S. A., Bogotá, Colombia, 158 pp.

SAS Institute Inc. (2009) Statitistical discovery software, JMP® 8, Cary, North Carolina, USA.

Savage, J.M.H. \& Heyer, W.R. (1997) Digital webbing formulae for anurans: a refinement. Herpetological Review, 28, 131.

Starrett, P.H. (1967) Observations on the life history of frogs of the family Atelopodidae. Herpetologica, 3, $195-204$.

Stuart, S.N., Chanson, J.S., Cox, N.A., Young, B.E., Rodrigues, A.S.L., Fischman, D.L. \& Waller, R.W. (2004) Status and trends of amphibian declines and extinctions worldwide. Science, 306, 1783-1786. 
Szymura, J.M. (1993) Analysis of hybrid zones with Bombina. New York and Oxford, Oxford University Press, 261-289 pp.

Valencia, R., Cerón, C., Palacios, W. \& Sierra, R. (1999) Las formaciones naturales de la Sierra del Ecuador. In: Sierra, R. (Ed.) Propuesta preliminar de un sistema de clasificación de vegetación para el Ecuador continental. Proyecto INEFAN/GERF-BIRF y Ecociencia, Quito, 79-108 pp.

Venegas, P. ( 2005) Atelopus peruensis. In: Rueda-Almonacid, J.V., Rodríguez-Mahecha, J.V., Marca, E.L., Lötters, S., Kahn, T. \& Angulo, A. (Eds.) Ranas Arlequines. Conservación Internacional. Panamericana Formas e Impresos S. A., Bogotá, Colombia, 150 pp.

von May, R., Catenazzi, A., Angulo, A., Brown, J.L., Carrillo, J., Chávez, G., Córdova, J.H., Curo, A., Delgado, A., Enciso, M.A., Gutiérrez, R., Lehr, E., Martínez, J.L., Medina-Müller, M., Miranda, A., Neira, D.R., Ochoa, J.A., Aarón, J.Q., Rodríguez, D.A., Rodríguez, L.O., Salas, A.W., Seimon, T., Seimon, A., Siu-Ting, K., Suárez, J., Torres, C. \& Twomey, E. (2008) Current state of conservation knowledge on threatened amphibian species in Perú. Tropical Conservation Science, 1, 376-396.

Wiens, J.J. (2007) Species delimitation: new approaches for discovering diversity. Systematic Biology, 56, 875-878.

Yánez-Muñoz, M. \& Altamirano B., M. (2005) Atelopus sp. 14. In: Rueda-Almonacid, J.V., Rodríguez-Mahecha, J.V., Lötters, S., La Marca, E., Kahn, T. \& Angulo, A. (Eds.) Ranas arlequines. Conservación Internacional. Panamericana Formas e Impresos S. A., Bogotá, 150 pp.

Zippel, K.C. \& Mendelson III, J.R. (2008) The amphibian extincion crisis: A call to action. Herpetological Review, 39, 23-29. 